\title{
Serum uric acid levels and multiple health outcomes: umbrella review of evidence from observational studies, randomised controlled trials, and Mendelian randomisation studies
}

\author{
(c) $\frac{(1)(8)}{\text { gy }}$ OPEN ACCESS
}

Xue Li PhD student ${ }^{1}$, Xiangrui Meng PhD student ${ }^{1}$, Maria Timofeeva statistical geneticist ${ }^{2}$, loanna Tzoulaki senior lecturer ${ }^{3}$, Konstantinos K Tsilidis assistant professor ${ }^{34}$, John PA loannidis professor ${ }^{5}$ ${ }^{67}$, Harry Campbell professor ${ }^{1}$, Evropi Theodoratou chancellor's fellow ${ }^{12}$

\begin{abstract}
${ }^{1}$ Centre for Global Health Research, Usher Institute of Population Health Sciences and Informatics, University of Edinburgh, Edinburgh EH8 9AG, UK; ${ }^{2}$ Colon Cancer Genetics Group, Medical Research Council Human Genetics Unit, Medical Research Council Institute of Genetics \& Molecular Medicine, University of Edinburgh, Edinburgh, UK ; ${ }^{3}$ Department of Epidemiology and Biostatistics, School of Public Health, Imperial College London, London, UK; ${ }^{4}$ Department of Hygiene and Epidemiology, University of loannina School of Medicine, loannina, Greece; ${ }^{5}$ Stanford Prevention Research Center, Stanford School of Medicine, Stanford, CA, USA; ${ }^{6}$ Department of Health Research and Policy, Stanford School of Medicine, Stanford, CA, USA; ${ }^{7}$ Department of Statistics, Stanford University, Stanford, CA, USA
\end{abstract}

\begin{abstract}
Objective To map the diverse health outcomes associated with serum uric acid (SUA) levels.

Design Umbrella review.

Data sources Medline, Embase, Cochrane Database of Systematic Reviews, and screening of citations and references.

Eligibility criteria Systematic reviews and meta-analyses of observational studies that examined associations between SUA level and health outcomes, meta-analyses of randomised controlled trials that investigated health outcomes related to SUA lowering treatment, and Mendelian randomisation studies that explored the causal associations of SUA level with health outcomes.

Results 57 articles reporting 15 systematic reviews and144 meta-analyses of observational studies (76 unique outcomes), 8 articles reporting 31 meta-analyses of randomised controlled trials (20 unique outcomes), and 36 articles reporting 107 Mendelian randomisation studies (56 unique outcomes) met the eligibility criteria. Across all three study types, 136 unique health outcomes were reported. 16 unique outcomes in meta-analyses of observational studies had $\mathrm{P}<10^{-6}, 8$ unique outcomes in meta-analyses of randomised controlled trials had $\mathrm{P}<0.001$, and 4 unique outcomes in Mendelian randomisation studies had $\mathrm{P}<0.01$. Large between study heterogeneity was common ( $80 \%$ and $45 \%$ in meta-analyses of observational studies and of randomised controlled trials, respectively). 42 (55\%) meta-analyses of observational studies
\end{abstract}

and 7 (35\%) meta-analyses of randomised controlled trials showed evidence of small study effects or excess significance bias. No associations from meta-analyses of observational studies were classified as convincing; five associations were classified as highly suggestive (increased risk of heart failure, hypertension, impaired fasting glucose or diabetes, chronic kidney disease, coronary heart disease mortality with high SUA levels). Only one outcome from randomised controlled trials (decreased risk of nephrolithiasis recurrence with SUA lowering treatment) had $\mathrm{P}<0.001$, a 95\% prediction interval excluding the null, and no large heterogeneity or bias. Only one outcome from Mendelian randomisation studies (increased risk of gout with high SUA levels) presented convincing evidence. Hypertension and chronic kidney disease showed concordant evidence in meta-analyses of observational studies, and in some (but not all) meta-analyses of randomised controlled trials with respective intermediate or surrogate outcomes, but they were not statistically significant in Mendelian randomisation studies.

Conclusion Despite a few hundred systematic reviews, meta-analyses, and Mendelian randomisation studies exploring 136 unique health outcomes, convincing evidence of a clear role of SUA level only exists for gout and nephrolithiasis.

\section{Introduction}

Uric acid was thought to be a biologically inert waste product from purine metabolism, until in the early 1800s it was 
discovered that an increased serum uric acid (SUA) level was the cause of gout. ${ }^{1}$ Subsequently, associations of uric acid concentration with cardiovascular and renal disorders were also observed. ${ }^{2}$ These associations were explored in several prospective studies but yielded conflicting results, and therefore the causal role of uric acid in these diseases was widely questioned. ${ }^{3456}$ It was argued that these associations are either confounded by other risk factors, such as obesity and hypertension, or are representative of reverse causality. ${ }^{47}$ These inconclusive findings led to a shift of interest away from uric acid, and asymptomatic hyperuricemia was not considered as an indication for SUA lowering treatment in patients with cardiovascular and renal diseases. ${ }^{89}$

New findings have fuelled enthusiasm to address this longstanding controversy. ${ }^{10}$ Recent epidemiological studies have explored associations of uric acid with a wide range of conditions (cardiovascular diseases, metabolic syndrome, diabetes, and cancer) and some intermediate phenotypes or biomarkers. ${ }^{11}$ In an attempt to understand the possible underlying mechanisms, laboratory studies have been carried out and found that uric acid is potentially involved in multiple biological processes, including oxidative stress, systemic inflammation, and intrahepatic fructose metabolism, all mechanisms that could be linked to the development of cardiovascular disease and metabolic syndrome. ${ }^{12} 1314$ Alternatively, uric acid level may only present a marker of high oxidative stress associated with increased xanthine oxidase activity, instead of being an active agent in the pathogenic processes ${ }^{15}$ Finally, taking into account the antioxidant properties of uric acid (acting as a free radical scavenger), its potential mechanistic roles in these disorders may be complex. ${ }^{16}$

In view of the potential importance of uric acid, assessing the credibility of the observed evidence may have implications both for clinical practice and public health. It is recognised that different types of studies have specific strengths and weaknesses that can be complementary (see box 1). An umbrella review, which collects and evaluates evidence from multiple resources systematically, might therefore help clarify the composite literature. We carried out an umbrella review of meta-analyses of observational studies, meta-analyses of randomised controlled trials, and Mendelian randomisation studies on associations between SUA level and multiple health outcomes. In particular, we summarised the range of related health outcomes, presented the magnitude, direction, and significance of the reported associations and effects, assessed the potential biases, and identified which associations and effects have the most convincing evidence.

\section{Methods}

\section{Literature search and selection criteria}

We systematically searched Medline, Embase, and the Cochrane Database of Systematic Reviews from inception to 17 July 2016 using a comprehensive search strategy (see table S1 in the web appendix) to identify systematic reviews and meta-analyses of observational studies, meta-analyses of randomised controlled trials, and Mendelian randomisation studies. All identified publications went through a three step parallel review of title, abstract, and full text (performed by XL and XM) based on predefined inclusion and exclusion criteria.

We included systematic reviews and meta-analyses of observational studies that examined associations between serum uric acid (SUA) levels (or hyperuricemia) and health outcomes; meta-analyses of randomised controlled trials that investigated health outcomes related to SUA lowering treatment (intervention with one or a combination of two or more SUA lowering drugs versus placebo or no treatment), including xanthine oxidase inhibitors (allopurinol, febuxostat, or oxypurinol), uricosuric agents (probenecid, benzbromarone, thiazides, or citrates), and uricase analogues (pegloticase or rasburicase); and Mendelian randomisation studies that explored SUA (or hyperuricemia) associations in relation to health outcomes by using genetic instruments influencing SUA levels. The identified health outcomes included a wide range of diseases, intermediate phenotypes, and biomarkers. We excluded studies investigating associations between gout and health outcomes and meta-analyses of randomised controlled trials that used non-drug interventions, such as dietary or lifestyle interventions. We further excluded animal and laboratory studies, meta-analyses on the prevalence of gout and hyperuricemia, and meta-analyses of randomised controlled trials that focused on drug variables, safety, and effects of reducing SUA levels without investigating other health effects.

\section{Data extraction}

One investigator (XL) extracted data, which were checked by a second investigator (XM). For each eligible study, we extracted the PubMed identification number, lead author's name, journal name, publication year, study population, number of studies included, and outcomes investigated. For meta-analyses investigating more than one health outcome, we recorded each outcome separately. For meta-analyses of observational studies and of randomised controlled trials, we extracted the reported summary risk estimates (risk ratio, odds ratio, hazard ratio, or mean difference) with the $95 \%$ confidence intervals and the corresponding number of case and control participants. Furthermore, for each unique outcome we extracted data from the individual component studies that were included in the meta-analyses for further analysis. This second level extraction included data on study design, number of cases, total number of participants, relative risk estimates, and $95 \%$ confidence intervals for each component study. When more than one meta-analysis existed for the same outcome in the same population, we extracted individual component data from the most recent and largest meta-analysis. In a few exceptions where the most recent was not also the largest meta-analysis, we explored the reason for this discrepancy. If the most recent included prospective studies and the largest one had fewer prospective studies plus some retrospective data, we kept the one with the largest amount of prospective data; otherwise we kept the largest meta-analysis. For Mendelian randomisation studies, we extracted data on study population, sample size, genetic instruments, the variance of SUA level explained by the genetic instruments $\left(\mathrm{R}^{2}\right)$ and Mendelian randomisation effect estimates (odds ratio, hazard ratio, mean difference, or regression coefficient $\beta$ ), standard deviation of SUA levels, and standard deviation of continuous outcomes.

\section{Data analysis}

For systematic reviews we performed descriptive analyses and presented the authors' conclusions. For each unique meta-analysis of observational studies and of randomised controlled trials, we estimated several metrics, including the summary effect and $95 \%$ confidence intervals using a random effect model (DerSimonian Laird method) ${ }^{17}$; the heterogeneity among studies (Q statistic and $\mathrm{I}^{2}$ metric with $95 \%$ confidence intervals); the $95 \%$ prediction interval to predict the range of effect size that would be expected in a new original study, after accounting for both the heterogeneity among individual studies and the uncertainty of the summary effect estimated in the 


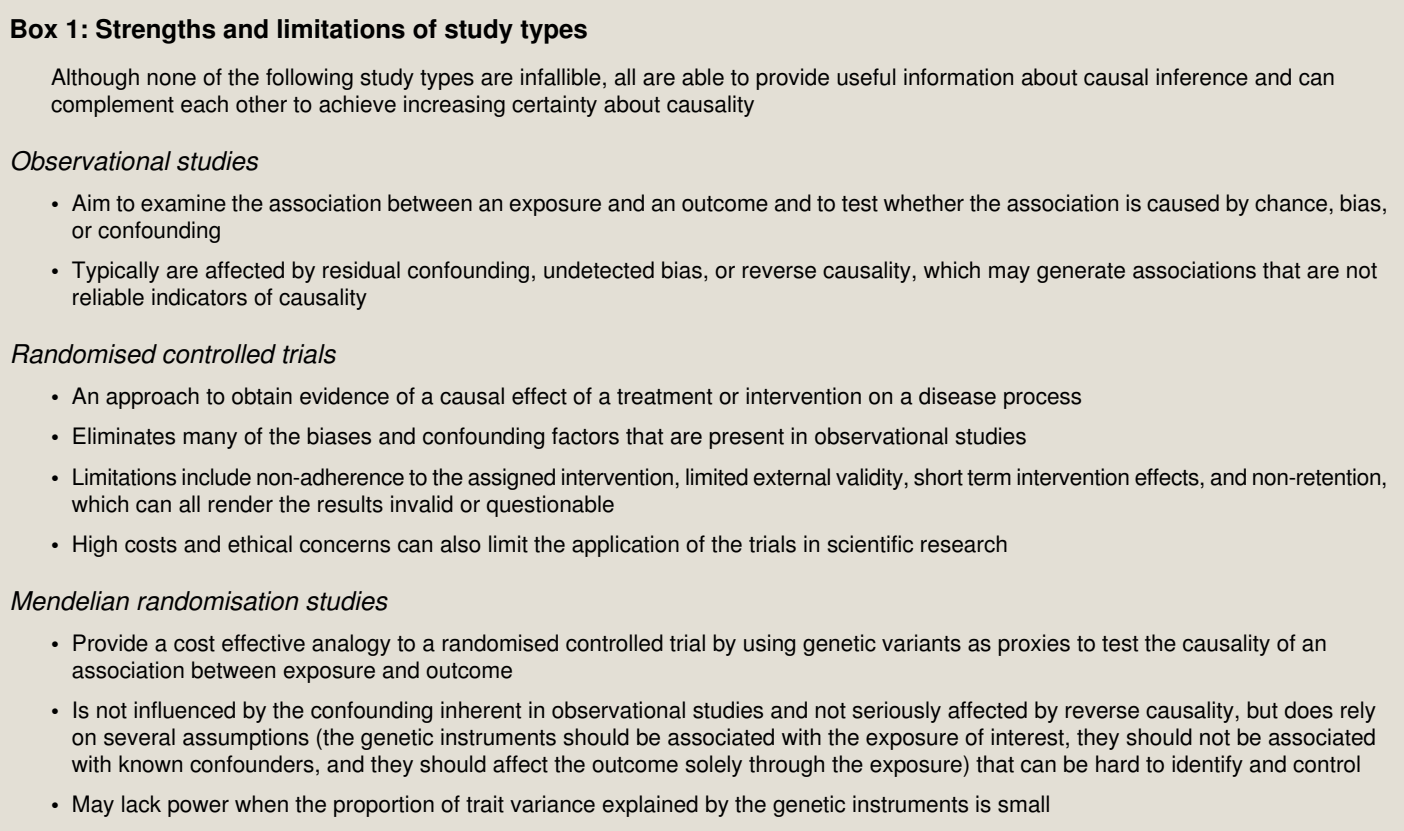

random effect model (the calculation of $95 \%$ prediction interval is based on the predicted distribution derived from a function of the degree of heterogeneity, number of studies included, and within study standard errors $)^{18}{ }^{19}$; the presence of small study effects by using the Egger's regression asymmetry test to investigate if small studies tend to give larger estimates of effect size than large studies (significance threshold $\mathrm{P}<0.10$ ) ${ }^{20}$; and the excess significance test to assess if the observed number (O) of studies with significant results was greater than the expected number (E) using the $\chi^{2}$ test:

$\mathrm{A}=\left[(\mathrm{O}-\mathrm{E})^{2} / \mathrm{E}+(\mathrm{O}-\mathrm{E})^{2} /(\mathrm{n}-\mathrm{E})\right]$ (significance threshold $\mathrm{P}<0.10){ }^{21}{ }^{22}$ For the excess significance test, we calculated the expected number $(\mathrm{E})$ of studies with significant findings by using the sum of statistical power estimated for each component study. The statistical power of each component study was calculated with an algorithm that uses a non-central $t$ distribution, by assuming the true effect size to be the same as that of the largest component study (with smallest variance) in the meta-analysis. ${ }^{23}$ If the type of metric in a meta-analysis was mean difference, we firstly calculated Cohen's d by weighing the pooled standard deviation based on the sample size of individual studies. We then transformed Cohen's d, Hedges g, and other standardised mean difference metrics to odds ratios. ${ }^{24}$ We compared the results reported in overlapping meta-analyses to evaluate their concordance in terms of the direction and statistical significance of the observed associations. All statistical analyses were conducted in Stata (StataCorp) version 14.0.

Owing to the extensive differences in genetic instruments used in the Mendelian randomisation studies we did not conduct quantitative syntheses. Instead, we performed and present here a descriptive analysis of the individual studies. When more than one Mendelian randomisation study was conducted for the same outcome, we compared the concordance of the findings for the direction and statistical significance of the reported association and retained the study with the largest number of cases and participants for further analysis and comparison. If all of the information required for calculation was provided (ie, sample size, number of cases, $\mathrm{R}^{2}$, estimates of association, standard deviation of continuous outcomes, and standard deviation of SUA levels), we performed a power calculation for the largest Mendelian randomisation studies by using the non-centrality parameter based approach. ${ }^{25}$ For Mendelian randomisation studies with missing $\mathrm{R}^{2}$ values, we performed a crude power estimation by using the $\mathrm{R}^{2}$ values from other Mendelian randomisation studies that used the same genetic variants as instruments.

\section{Credibility assessment}

As previously proposed, ${ }^{26}$ we classified evidence from meta-analyses of observational studies with nominally statistically significant summary results $(\mathrm{P}<0.05)$ into four categories (class I, II, III, and IV). Convincing (class I) evidence was assigned to associations with a statistical significance of $\mathrm{P}<10^{-6}$, included more than 1000 cases (or more than 20000 participants for continuous outcomes), had the largest component study reporting a significant result $(\mathrm{P}<0.05)$, had a 95\% prediction interval that excluded the null, did not have large heterogeneity $\left(\mathrm{I}^{2}<50 \%\right)$, and showed no evidence of small study effects $(\mathrm{P}>0.10)$ and of excess significance bias $(\mathrm{P}>0.10)$. Highly suggestive (class II) evidence was assigned to associations that reported a significance of $\mathrm{P}<0.001$, included more than 1000 cases (or more than 20000 participants for continuous outcomes), and had the largest component study reporting a statistically significant result $(\mathrm{P}<0.05)$. Suggestive (class III) evidence was assigned to associations that reported a significance of $\mathrm{P}<0.01$ with more than 1000 cases (or more than 20000 participants for continuous outcomes). Weak (class IV) evidence was assigned to the remaining significant associations with $\mathrm{P}<0.05$. For each association in the convincing or highly suggestive categories we reassessed the evidence after excluding the retrospective and case-control studies in an attempt to address reverse causality. Finally, for each association in the convincing category we reassessed the evidence after we examined each meta-analysis in depth by assessing the eligibility of the included studies as well as verifying the data used in the meta-analysis.

Evidence from meta-analyses of randomised controlled trials was assessed in terms of the significance of the summary effect $(\mathrm{P}<0.01,0.01 \leq \mathrm{P}<0.05, \mathrm{P} \geq 0.05), 95 \%$ prediction interval (excluding the null or not), and presence of large heterogeneity $\left(\mathrm{I}^{2}>50 \%\right)$, small study effects $(\mathrm{P}>0.10)$, and excess significance $(\mathrm{P}>0.10)$. We also noted the conclusions from any evidence classification (GRADE ${ }^{27}$ or equivalent system) applied by the 
original meta-analyses. Finally, we assessed the evidence from individual Mendelian randomisation studies for statistical significance of the effect estimate $(\mathrm{P}<0.01)$ and of the statistical power $(>80 \%){ }^{28}$

For overlapping outcomes that were investigated in meta-analyses of observational studies and/or meta-analyses of randomised controlled trials and/or individual Mendelian randomisation studies, we examined if the direction and statistical significance of the associations were reported concordantly across the different study types. We noted the overlapping outcomes that were graded as class I or II in meta-analyses of observational studies and had a $95 \%$ prediction interval excluding the null in meta-analyses of randomised controlled trials. For these outcomes we also presented the evidence from Mendelian randomisation studies if available.

\section{Patient involvement}

No patients were involved in setting the research question or the outcome measures, nor were they involved in developing plans for design or implementation of the study. No patients were asked to advise on interpretation or writing up of results. There are no plans to disseminate the results of the research to study participants or the relevant patient community.

\section{Results}

\section{Literature review}

Overall, the parallel reviews identified 4608 publications across three databases. After applying the inclusion or exclusion criteria, 101 publications were selected for inclusion (fig $1 \Downarrow$ ). Specifically, 15 systematic reviews and 144 meta-analyses of observational studies were reported in 57

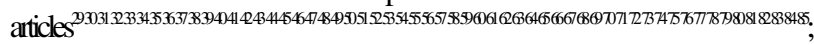
31 meta-analyses of randomised controlled trials were reported in 8 articles ${ }^{868788} 8990919293$; and 107 Mendelian randomisation studies were reported in 36 articles (see tables S2 to S5, respectively, in web

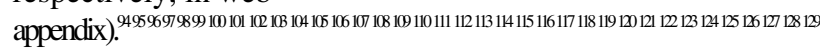

Across all three study types, 136 unique outcomes were reported.

\section{Meta-analyses of observational studies}

Overall, 144 meta-analyses of observational studies were identified (see table S3in web appendix). The median number of studies included in meta-analyses was 5 (range 2-31), the median number of participants was 7932 (129-1 017 810), and the median number of cases was 1176 (49-34 370). More than one meta-analysis was conducted for 16 outcomes (see table S3 in web appendix). The direction and statistical significance of the reported associations in overlapping meta-analyses were concordant for 14 (88\%) outcomes: atrial fibrillation incidence $(\mathrm{n}=3),{ }^{39} 5282$ coronary heart disease $(\mathrm{n}=4),{ }^{41} 7276{ }^{83}$ hypertension incidence $(n=3),{ }^{44} 74$ stroke incidence $(n=2),{ }^{48} 75$ diabetes $(\mathrm{n}=3),{ }^{49} 5079$ chronic kidney disease $(\mathrm{n}=3),{ }^{5455} 77$ mild cognitive impairment $(\mathrm{n}=2),{ }^{58}{ }^{80}$ Parkinson's disease $(\mathrm{n}=3),{ }^{58}{ }^{51}$ multiple sclerosis $(n=2),{ }^{60} 78$ coronary heart disease mortality $(n=3),{ }^{41} 7276$ cardiovascular disease mortality $(\mathrm{n}=2),{ }^{65}$ stroke mortality $(\mathrm{n}=2),{ }^{48} 75$ all cause mortality in patients with heart failure $(\mathrm{n}=2),{ }^{43}{ }^{67}$ and all cause mortality in the general population $(n=2) .{ }^{65}{ }^{84}$ Discordance in the statistical significance was present for two outcomes: diabetic neuropathy $(\mathrm{n}=2)^{5153}$ and Alzheimer's disease $(n=4) .57587380$

After removing the overlapping meta-analyses (which were conducted in the same population for the same outcome), 76 unique meta-analyses were retained. The meta-analyses reported a wide range of outcomes (table $1 \Downarrow$ ): cardiovascular outcomes $(n=13)$, diabetes related outcomes $(n=9)$, kidney disorders $(n=7)$, neurocognitive disorders $(n=11)$, cancer outcomes $(n=6)$, all cause or cause specific mortality $(n=22)$, and other outcomes $(n=8)$. Overall, 58 (76\%) of the 76 non-overlapping meta-analyses reported nominally significant summary results $(\mathrm{P}<0.05)$. Figures 1 and 2 in the web appendix show the summary effects of the unique meta-analyses of observational studies. Of these, $12(92 \%)$ meta-analyses in cardiovascular outcomes, 8 (89\%) in diabetes related outcomes, all $7(100 \%)$ in kidney disorders, $1(9 \%)$ in neurocognitive disorders, $1(17 \%)$ in cancer outcomes, $15(68 \%)$ in all cause and cause specific mortality, and $6(75 \%)$ in other outcomes reported summary estimates with $\mathrm{P}<0.05$ and suggested that high levels of SUA were associated with an increased risk of disease. In addition, $7(64 \%)$ meta-analyses in neurocognitive disorders and $1(12 \%)$ in other outcomes (composite of adverse outcomes (death or major adverse cardiovascular event) in patients with acute ischaemic stroke) reported summary estimates with $\mathrm{P}<0.05$ and suggested inverse associations with SUA level.

We then applied our evidence classification criteria. Sixteen $(21 \%)$ meta-analyses had $\mathrm{P}<10^{-6}, 10(13 \%)$ had a $95 \%$ prediction interval that excluded the null, 27 (36\%) had more than 1000 cases (or more than 20000 participants for continuous outcomes), 15 (20\%) had no large heterogeneity $\left(\mathrm{I}^{2}<50 \%\right)$, and $34(45 \%)$ had neither small study effects nor excess significant bias. Based on these metrics, only one of $76(1 \%)$ outcomes presented convincing evidence (class I: stroke mortality in general population), 7 (9\%) outcomes presented highly suggestive evidence (class II: heart failure incidence, hypertension incidence, impaired fasting glucose or diabetes, chronic kidney disease incidence, coronary heart disease mortality, all cause mortality in patients with heart failure, and non-alcoholic fatty liver disease), and 9 (12\%) outcomes presented suggestive evidence (class III: atrial fibrillation, coronary heart disease incidence, cardiovascular disease, prehypertension, medium term major adverse cardiac event, type 2 diabetes, cardiovascular disease mortality, chronic kidney disease mortality, death, or cardiac events). The remaining 41 (54\%) statistically significant outcomes presented weak evidence (class IV).

We performed a thorough examination and reassessed the meta-analyses of stroke mortality ${ }^{48}$ (class I) and found that data from the largest study were incorrect (the events represented stroke incidence cases rather than stroke deaths and the included study had not published data on stroke mortality). ${ }^{130}$

Furthermore, the data from two individual studies reported comparisons of SUA categories that differed from other studies (the highest sextile versus the second or third sextile rather than the lowest), ${ }^{131} 132$ and a fourth study had been using only data on ischaemic stroke deaths but missing the data on haemorrhagic stroke deaths. ${ }^{133}$ When we excluded the stroke incidence study, used the proper comparison for the other two studies, and added the missing data in the fourth study, the association with stroke mortality was not statistically significant (table $2 \Downarrow$ ). For the highly suggestive outcomes (class II), when we limited the data to prospective cohort studies, all associations retained their ranking, except for all cause mortality in patients with heart failure and non-alcoholic fatty liver disease, which were downgraded to class III (table $\mathrm{X}$ in the web appendix).

\section{Meta-analyses of randomised controlled trials}

We identified 31 meta-analyses of randomised controlled trials on SUA lowering treatment from eight publications (see table S4 in web appendix). The median number of studies included 
in the meta-analyses was 5 (range 2-10) and the median number of participants was 216 (41-738). More than one meta-analysis was found for five outcomes (see table S4 in web appendix). The direction and statistical significance of the effects in overlapping meta-analyses were in concordance only for one (20\%) outcome: serum creatinine level $(\mathrm{n}=2){ }^{88}{ }^{89}$ Discordance in either the direction and/or the statistical significance was found for the remaining four outcomes: glomerular filtration rate $(\mathrm{n}=2),{ }^{88}{ }^{89}$ end stage kidney disease $(\mathrm{n}=2),{ }^{88} 89$ systolic blood pressure $(\mathrm{n}=2),{ }^{89}{ }^{93}$ and diastolic blood pressure $(\mathrm{n}=2){ }^{89} 93$

Twenty unique meta-analyses (table $3 \Downarrow$ ) were identified for the outcomes in relation to kidney disorders $(n=10)$, endothelial function $(n=2)$, all cause and cause specific mortality $(n=4)$, and other outcomes $(n=4)$. Figure 3 in the web appendix shows the summary effects of the unique meta-analyses of randomised controlled trials. Overall, $12(60 \%)$ reported a nominally significant summary result at $\mathrm{P}<0.05(8$ had $\mathrm{P}<0.001)$. Only three $(15 \%)$ meta-analyses had a $95 \%$ prediction interval that excluded the null (two nephrolithiasis outcomes (with thiazide and citrate treatment) and one renal function outcome), 11 (55\%) meta-analyses showed no large heterogeneity $\left(\mathrm{I}^{2}<50 \%\right)$, and 13 $(65 \%)$ meta-analyses showed neither small study effects nor excess significant bias.

Only one outcome (recurrence of nephrolithiasis with citrates treatment) reported a $\mathrm{P}<0.001$, had a $95 \%$ prediction interval excluding the null, and had no evidence of large heterogeneity or bias. In the original meta-analyses, the strength of evidence was graded collectively for three nephrolithiasis outcomes (thiazide, citrate, or allopurinol treatment) by using an approach conceptually similar to the GRADE ranking system, ${ }^{134}$ and evidence for these three nephrolithiasis outcomes was graded as moderate.

\section{Mendelian randomisation studies}

A total of 107 Mendelian randomisation analyses were identified from 36 publications (see table S5 in web appendix). The median number of participants was 7158 (range 343-206 822) and median number of cases was 2225 (19-65 877). The proportion of variance in SUA level $\left(\mathrm{R}^{2}\right)$ explained by genetic instruments was 2-6\%. More than one Mendelian randomisation study was identified for 14 outcomes (see table S5 in web appendix). Discordance in either the direction and/or the statistical significance of association among overlapping Mendelian randomisation existed for all the identified outcomes: body mass index $(\mathrm{n}=7), 9596101102110115121$ bone mineral density in femoral neck $(n=2),{ }^{97} 98$ coronary heart disease $(n=5),{ }^{96} 100106118126$ diastolic blood pressure $(\mathrm{n}=7),{ }^{96} 101106110119121124$ systolic blood pressure $(\mathrm{n}=7),{ }^{96101} 106110119121{ }^{124}$ metabolic syndrome $(\mathrm{n}=2),{ }^{107} 120$ glucose level $(n=3),{ }^{96} 106121$ triglyceride level $(n=3),{ }^{96121} 123$ diabetes (n=6), ${ }^{96} 99105100122127$ serum creatinine level $(n=2),{ }^{110} 129$ estimated glomerular filtration rate $(n=5),{ }^{106} 110121128129$ Parkinson's disease $(\mathrm{n}=5),{ }^{111} 112116117125$ memory performance $(\mathrm{n}=2),{ }^{114}$ and gout $(\mathrm{n}=3) .{ }^{99} 100106$

The 56 unique outcomes (table $4 \Downarrow$ ) investigated in individual Mendelian randomisation studies belonged to the following categories: anthropometric variables $(n=9)$, cardiovascular outcomes $(n=15)$, kidney disorders $(n=6)$, metabolic disorders $(n=5)$, neurocognitive disorders $(n=5)$, metabolites $(n=11)$, all cause and cause specific mortality $(\mathrm{n}=3)$, and other outcomes $(n=2)$. Only nine $(16 \%)$ outcomes (diabetic macrovascular disease, arterial stiffness (internal diameter of carotid artery), adverse renal events, Parkinson's disease, lifetime anxiety disorders, memory performance, cardiovascular disease mortality, sudden cardiac death, and gout) presented significant associations of $\mathrm{P}<0.05$. Three Mendelian randomisation studies (on memory performance, Parkinson's disease, and gout) reported discordant results in the direction and/or statistical significance in other Mendelian randomisation studies. Of note, only four outcomes (diabetic macrovascular disease, arterial stiffness (internal diameter of carotid artery), renal events, and gout) reported a $\mathrm{P}<0.01$, and only that for gout was based on convincing evidence $(\mathrm{P}=3.55 \mathrm{E}-40, \mathrm{n}=71501$, power $>99 \%)$.

\section{Comparison of findings from meta-analyses}

Table $5 \Downarrow$ summarises the outcomes reported in meta-analyses of observational studies with highly suggestive evidence or meta-analyses of randomised controlled trials with $95 \%$ prediction intervals excluding the null. Among these outcomes, hypertension and chronic kidney disease showed concordant evidence between meta-analyses of observational studies and the selected (largest) meta-analyses of randomised controlled trials on their corresponding intermediate traits or surrogate outcomes (eg, systolic blood pressure, diastolic blood pressure, serum creatinine level, estimated glomerular filtration rate, and end stage renal disease) but had discordant evidence from Mendelian randomisation studies. Moreover, even for these outcomes there were additional meta-analyses of randomised controlled trials that had found discordant effects in terms of direction and/or statistical significance for all these intermediate traits or surrogate outcomes, with the exception of serum creatinine level. Heart failure, impaired fasting glucose or diabetes, and coronary heart disease mortality showed no evidence from meta-analyses of randomised controlled trials, and Mendelian randomisation studies reported discordant evidence on the corresponding outcomes, the intermediate traits, or the surrogate outcomes. Recurrence of nephrolithiasis was only reported in meta-analysis of randomised controlled trials, and no evidence was found from meta-analyses of observational studies or Mendelian randomisation studies.

\section{Discussion}

In this study, we provide a comprehensive overview of reported associations between serum uric acid (SUA) levels and a wide range of health outcomes by incorporating evidence from systematic reviews andmeta-analyses of observational studies, meta-analyses of randomised controlled trials, and Mendelian randomisation studies. We also further evaluated the reported evidence by following criteria that we have previously applied to appraise the epidemiological credibility in several research specialties. ${ }^{26} 135136$ Our study comprised 76 unique meta-analyses of observational studies, 20 unique meta-analyses of randomised controlled trials, and 56 unique individual Mendelian randomisation studies, which overall covered 136 unique health outcomes.

\section{Main findings and possible explanations}

Most health outcomes that were reported to be associated with SUA level were identified from meta-analyses of observational studies, but after the application of our criteria none of them were classified as convincing (class I). Highly suggestive evidence (class II) existed for five health outcomes, including heart failure, hypertension, impaired fasting glucose or diabetes, chronic kidney disease, and coronary heart disease mortality in the general population. Notably, a large proportion $(80 \%)$ of the examined meta-analyses displayed substantial heterogeneity $\left(I^{2}>50 \%\right)$, indicating that these associations should be interpreted with caution. Possible sources of the observed heterogeneity include the mixture of prospective, retrospective, or case-control 
studies and the mixture of different comparison groups, since some meta-analyses synthesised individual studies with diverse contrasted categories of SUA levels (eg, various choices of tertiles, quartiles, quintiles, or sextiles of SUA levels). Likewise, although the outcomes with class I or II evidence fulfilled the criteria of credibility assessment for meta-analyses of observational studies, it would be inadvisable to conclude causation on this basis alone, owing to the inherent limitations of unmeasured confounding, undetected bias, or reverse causality in observational studies. In relation to reverse causality for example, some of the associations that were initially classified as class II (eg, all cause mortality in patients with heart failure and non-alcoholic fatty liver disease), were no longer highly suggestive (and were downgraded to class III) when focusing on prospective observational data and excluding the retrospective studies.

Current evidence from meta-analyses of randomised controlled trials was limited to the beneficial effects of SUA lowering treatment on some intermediate traits or biomarkers related to cardiovascular and renal disorders (eg, blood pressure, endothelial functions, and renal function). However, when multiple meta-analyses of randomised controlled trials existed for traits or markers, often the results were not concordant in direction of effect and/or statistical significance. Although 12 health outcomes had $\mathrm{P}<0.05$, only recurrence of nephrolithiasis with citrate treatment achieved $\mathrm{P}<0.001$, with $95 \%$ prediction interval excluding the null. Two additional health outcomes (recurrence of nephrolithiasis using thiazides and end stage renal disease in patients with coronary heart disease using allopurinol) also had a 95\% prediction interval excluding the null. Large heterogeneity and evidence of bias were common even in meta-analyses of randomised controlled trials (in $45 \%$ of meta-analyses and $35 \%$ of randomised controlled trials). When incorporating evidence from meta-analyses of randomised controlled trials with that from meta-analyses of observational studies, there was a notable gap, as health outcomes that were investigated in meta-analyses of observational studies and classified as class I or II have generally not been evaluated in meta-analyses of randomised controlled trials. In a few cases, data from randomised controlled trials on surrogate outcomes (eg, systolic blood pressure, diastolic blood pressure, and renal function tests) that corresponded to disease outcomes in observational studies (hypertension, chronic kidney disease) were available, but conclusions from extrapolation of surrogate outcomes, which were evaluated in short term trials, to long term clinical outcomes should be treated with caution.

As an alternative to randomised controlled trials, the Mendelian randomisation design has been developed for exploring the causal effect of biomarkers on health outcomes. Fifty six Mendelian randomisation studies were identified that explored the causal role of SUA in cardiovascular, metabolic, neurocognitive, and renal disorders or related traits and biomarkers. In contrast with the meta-analyses of observational studies where most of the results $(76 \%)$ were significant at $\mathrm{P}<0.05$, most $(84 \%)$ health outcomes investigated in Mendelian randomisation studies were not statistically significant. The generally negative results across so many health outcomes suggest that the large effects have probably not been missed, but most of the included Mendelian randomisation studies could have been underpowered to detect modest effects. When retaining the largest Mendelian randomisation study for each health outcome, significant results with $\mathrm{P}<0.05$ were only reported for nine health outcomes, and only four of these health outcomes (diabetic macrovascular disease, arterial stiffness (internal diameter of carotid artery), renal events, and gout) had
$\mathrm{P}<0.01$, whereas only the gout outcome was based on evidence from a Mendelian randomisation study with adequate power. Of the other five health outcomes with $\mathrm{P}<0.05$, Parkinson's disease and memory performance had at least one other Mendelian randomisation study that was not significant or had an association in the opposite direction.

Several instrumental variable assumptions need to be fulfilled for the results of a Mendelian randomisation analysis to be valid. The first assumption states that the genetic instrument should be strongly associated with the intermediate phenotype. SUA level has an evident heritable component with an overall heritability of $40-60 \%,{ }^{137}$ but the strength of genetic instruments used in Mendelian randomisation studies was small or moderate, accounting for only $2-6 \%$ of SUA variance. Currently, the proportion of SUA variance explained by all common genetic variants identified by a genome wide association study remains relatively small (7\%). ${ }^{138}$ This limits the power of genetic instruments to detect causal associations with SUA level. The second and third assumptions (the instrument is associated with the outcome through the studied exposure only and the genotype is independent of other factors that affect the outcome) are more difficult to evaluate given the largely unknown complexity and interconnectedness of biological pathways underlying the genetic variants related to SUA level. The included Mendelian randomisation studies tried to validate these assumptions either by excluding single nucleotide polymorphisms related to other known confounding factors, by excluding single nucleotide polymorphisms that had potential pleiotropic effects, or by applying new Mendelian randomisation methods to account for pleiotropic effects (eg, Egger Mendelian randomisation analysis or network Mendelian randomisation).

\section{Clinical implications and future research}

Current recommendations on the drug treatment of hyperuricemia are related to gout or nephrolithiasis. ${ }^{8}$ Since a wide range of health outcomes has been identified to be associated with SUA level, a renewed interest in whether individuals with asymptomatic hyperuricemia should be treated with SUA lowering drugs for the prevention or treatment of associated cardiovascular and metabolic diseases. In this study we raised large uncertainty about the potential therapeutic benefits of an expansion of SUA lowering treatment. Although we identified some highly suggestive associations from observational studies, there was a lack of concordance with clinically relevant endpoints from randomised controlled trials or surrogate endpoints from Mendelian randomisation studies, and therefore evidence is insufficient to support any SUA lowering drug intervention for these outcomes. Furthermore, the adverse effects of SUA lowering drugs should be taken into consideration (eg, an estimated $0.1 \%$ of patients treated with allopurinol, the first line SUA lowering drug, develop allopurinol hypersensitivity syndrome, which can be life threatening). ${ }^{9}$

Our study does not support one of the recommendations in the recently updated European League Against Rheumatism gout treatment guidelines, which suggest that SUA level $<3.0 \mathrm{mg} / \mathrm{dL}$ is not recommended for gout management in the long term. ${ }^{139}$ This recommendation is based on several observational studies in which low SUA levels were associated with increased risk of multiple neurological diseases, including Alzheimer's disease and Parkinson's disease. ${ }^{140} 141142$ However, in our umbrella review a number of meta-analyses reported nominally statistically significant associations of low SUA levels with increased risk of multiple neurological diseases, but several other meta-analyses (9 out of 28) did not support these findings. Moreover, our credibility assessment showed that the nominally 
significant associations were consistent with class IV evidence, and a causal effect has not consistently been established for any neurological disease in Mendelian randomisation studies. Therefore, there is no adequate evidence against lowering SUA levels in patients with gout because of an increased risk of neurological diseases.

For future research, efforts to address the limitations and caveats in current evidence will be beneficial. In particular, as the current clinical trials of SUA lowering treatment largely focus on the effect of allopurinol on some intermediate traits or biomarkers, the effect of SUA reduction on clinically relevant endpoints of the convincing and highly suggestive associations might be worth further investigation. In addition, efforts to evaluate whether other SUA lowering agents have the same effect as xanthine oxidase inhibitors will help to determine if these effects are truly due to the SUA reduction itself rather than the mechanisms of xanthine oxidase inhibition. Finally, noting the largely discordant evidence in Mendelian randomisation studies, better designed such studies with collaboration of large international consortiums might assist in deciding whether the lack of replication of highly suggestive findings of observational studies is owing to low power to detect moderate or small effects, or owing to truly negative effects.

\section{Strengths and weaknesses of this review}

The strengths of umbrella reviews have been described in detail. ${ }^{26} 135136$ Here we summarised and presented the evidence of the associations between SUA level and a wide spectrum of health related outcomes systematically and thoroughly by incorporating information from meta-analyses of observational studies, meta-analyses of randomised controlled trials, and Mendelian randomisation studies. We then calculated a number of additional metrics and applied well defined criteria to assess the credibility of the observed associations.

In relation to study weaknesses, umbrella reviews focus on existing meta-analyses and therefore outcomes that were not assessed in a meta-analysis are not included in the review. For example, we found no formal meta-analysis of observational studies on SUA level and urolithiasis or gout, even though these associations are well established. Although there are some differences in SUA levels between men and women, there is not sufficient evidence at a meta-analysis level and therefore we did not attempt to perform subgroup analyses by sex. To avoid subjectivity, we did not include reviews without explicit systematic literature searches, but this could limit the breadth of the results to some extent, if some non-systematic reviews cover questions that have not been addressed by systematic reviews. ${ }^{143}{ }^{144}$ Furthermore, we did not appraise the quality of the individual studies, since this should be the responsibility of the authors of the original meta-analysis and it was beyond the scope of the current umbrella review.

We adopted credibility assessment criteria, which were based on established tools for observational evidence, and their individual limitations have been summarised previously. ${ }^{26} 135136$ None of the components of these criteria provides firm proof of lack of reliability, but they cumulatively map the possibility that the results are susceptible to bias and uncertainty. Given the wide variety of study designs and populations considered in several of the meta-analyses, one might claim that large heterogeneity in particular may not necessarily be worrisome. However, considering it is difficult to differentiate the real heterogeneity from the heterogeneity that reflects some forms of bias or uncertainty, we applied $\mathrm{I}^{2}<50 \%$ as one of the criteria for class I evidence (convincing) for meta-analyses of observational studies, so as to assign the top evidence grade only to associations that are most robust and without hints of bias. In most cases $\mathrm{I}^{2}>50 \%$ indicates the presence of component studies with opposite effects or of component studies with and without statistically significant associations. However, nine meta-analyses of observational studies classified as class II, III, or IV had an $\mathrm{I}^{2}>50 \%$, with all component studies reporting a statistically significant association of the same direction. Only one of these nine meta-analyses (heart failure incidence) would be upgraded from class II to class I if we did not consider the heterogeneity criterion, since the other eight also failed additional class I criteria. No meta-analyses of randomised controlled trials had an $\mathrm{I}^{2}>50 \%$ with all component studies reporting a statistically significant association with the same direction.

Finally, another limitation of the umbrella review approach is the use of existing meta-analyses taking their results at face value. Meta-analyses are known to have common flaws ${ }^{145}$ and their results may also depend on choices made about what estimates to select from each primary study and how to represent them in the meta-analysis (eg, in what contrast of exposure levels). This may be a common problem when the factor of interest is continuous, as in the case of SUA level, and where different comparisons of levels of the risk factor may be selected to express risk. ${ }^{146} \mathrm{We}$ therefore decided to investigate any meta-analyses with seemingly convincing evidence in more detail. In this process, the only meta-analysis that seemed to achieve convincing evidence (class I: stroke mortality) was found to actually have major flaws. Recalculation of the results showed that the evidence was downgraded to not statistically significant. It is possible that similar thorough evaluations might have downgraded the credibility of some additional meta-analyses. In addition, we noted that many primary studies are represented in the calculations of meta-analyses by using only a small subset of the data of extreme groups (eg, as the risk ratio for an event in extreme quintiles of SUA levels). In these cases, the number of events pertinent to these extreme groups may be much fewer than the total number of events used in calculating the amount of evidence criteria. Therefore, some meta-analyses that seemingly include studies with more than 1000 cases may actually capture fewer than 1000 cases in the main calculations and thus their grading appraisal should have been weaker. These flaws and deficiencies are difficult to decipher without a thorough reconstruction of all observational meta-analyses, and they may explain why observational evidence for SUA associations generally did not show good concordance with evidence from randomised controlled trials and Mendelian randomisation studies in our umbrella evaluation.

Meta-analyses of observational data for SUA level and other risk factors need to be strengthened. For continuous putative risk factors such as SUA concentration, a consensus on the categorisation of levels of interest would be useful. This might be achieved by careful meta-analyses of individual level data in inclusive consortiums. This approach would allow a more accurate and reliable exploration of both linear and non-linear associations (eg, the possibility of U-shaped associations with increased risk at both very high and very low levels). Currently available data from meta-analyses do not allow for consistent handling and assessment of such non-linear relations.

Conversely, data dredging using different categorisations of SUA levels for comparison is likely to fuel a literature with spurious associations. ${ }^{147}$ 


\section{Conclusion}

This comprehensive umbrella review will help investigators to judge the relative priority of health outcomes related to SUA level for future research and clinical management of disease. In summary, despite a few hundred systematic reviews, meta-analyses, and Mendelian randomisation studies exploring 136 unique health outcomes, convincing evidence of a clear role of SUA level only exists for gout and nephrolithiasis. Concordant evidence between observational studies and randomised controlled trials existed for hypertension and chronic kidney disease, but a potential causal role of SUA level for these outcomes has not been verified by current Mendelian randomisation studies and even for these two outcomes not all meta-analyses of randomised controlled trials are concordant among themselves and with observational evidence. Therefore, the available evidence does not support any change in the existing clinical recommendations in relation to hyperuricemia.

Contributors: ET and HC conceived the study and JPAI contributed to the design. $X L$ and $X M$ performed the systematic review and data extraction. $\mathrm{XL}$ performed the statistical analysis. $\mathrm{XL}$ and $\mathrm{ET}$ wrote the manuscript. HC, JPAI, KKT, MT, and IT critically reviewed the manuscript and contributed important intellectual content. All authors have read and approved the final manuscript as submitted. ET is the guarantor. Funding: XL and XM are supported by the China Scholarship Council. ET is supported by a CRUK Career Development Fellowship.

Competing interests: All authors have completed the ICMJE uniform disclosure form at www.icmje.org/coi_disclosure.pdf (available on request from the corresponding author) and declare: no support from any organisation for the submitted work; no financial relationships with any organisations that might have an interest in the submitted work in the previous three years; no other relationships or activities that could appear to have influenced the submitted work.

Ethical approval: Not required.

Data sharing: No additional data available.

Transparency: The manuscript's guarantor (ET) affirms that the manuscript is an honest, accurate, and transparent account of the study being reported; that no important aspects of the study have been omitted; and that any discrepancies from the study as planned (and, if relevant, registered) have been explained.

Garrod AB. Observations on certain pathological conditions of the blood and urine, in gout, rheumatism, and Bright's disease. Med Chir Trans 1848;31:83-97. doi:10.1177/ 095952874803100109pmid:20895908.

2 Davis NS Jr. The cardio-vascular and renal relations and manifestations of gout. JAMA 1897;XXIX:261-2doi:10.1001/jama.1897.02440320005001a.

3 Freedman DS, Williamson DF, Gunter EW, Byers T. Relation of serum uric acid to mortality and ischemic heart disease. The NHANES I Epidemiologic Follow-up Study. Am J Epidemiol 1995:141:637-44. doi:10.1093/oxfordjournals aje.a117479pmid:7702038.

4 Culleton BF, Larson MG, Kannel WB, Levy D. Serum uric acid and risk for cardiovascular disease and death: the Framingham Heart Study. Ann Intern Med 1999;131:7-13. doi:10. 7326/0003-4819-131-1-199907060-00003pmid:10391820.

5 Wannamethee SG, Shaper AG, Whincup PH. Serum urate and the risk of major coronary heart disease events. Heart 1997;78:147-53. doi:10.1136/hrt.78.2.147pmid:9326988.

6 Vaccarino V, Krumholz HM. Risk factors for cardiovascular disease: one down, many more to evaluate. Ann Intern Med 1999;131:62-3. doi:10.7326/0003-4819-131-1199907060-00012pmid:10391817.

7 Feig DI, Kang D-H, Johnson RJ. Uric acid and cardiovascular risk. N Engl J Med 2008;359:1811-21. doi:10.1056/NEJMra0800885pmid:18946066.

8 Khanna D, Fitzgerald JD, Khanna PP, et al. American College of Rheumatology. 2012 American College of Rheumatology guidelines for management of gout. Part 1: systematic nonpharmacologic and pharmacologic therapeutic approaches to hyperuricemia. Arthritis Care Res (Hoboken) 2012;64:1431-46. doi:10.1002/acr.21772pmid:23024028.

9 Stamp L, Dalbeth N. Urate-lowering therapy for asymptomatic hyperuricaemia: A need for caution. Semin Arthritis Rheum 2016.pmid:27591828.

10 Nakagawa $\mathrm{T}$, Kang DH, Feig D, et al. Unearthing uric acid: an ancient factor with recently found significance in renal and cardiovascular disease. Kidney Int 2006;69:1722-5. doi: 10.1038/sj.ki.5000391 pmid:16598194.

11 Soltani Z, Rasheed K, Kapusta DR, Reisin E. Potential role of uric acid in metabolic syndrome, hypertension, kidney injury, and cardiovascular diseases: is it time for reappraisal? Curr Hypertens Rep 2013;15:175-81. doi:10.1007/s11906-013-0344-5pmid: 23588856.

12 George J, Struthers AD. Role of urate, xanthine oxidase and the effects of allopurinol in vascular oxidative stress. Vasc Health Risk Manag 2009;5:265-72. doi:10.2147/VHRM. S4265pmid:19436671.
13 Meotti FC, Jameson GN, Turner R, et al. Urate as a physiological substrate for myeloperoxidase: implications for hyperuricemia and inflammation. $J$ Biol Chem 2011;286:12901-11. doi:10.1074/jbc.M110.172460pmid:21266577.

14 Nakagawa T, Hu H, Zharikov S, et al. A causal role for uric acid in fructose-induced metabolic syndrome. Am J Physiol Renal Physiol 2006;290:F625-31. doi:10.1152/ajprenal. 00140.2005pmid:16234313.

15 Pasalic D, Marinkovic N, Feher-Turkovic L. Uric acid as one of the important factors in multifactorial disorders--facts and controversies. Biochem Med (Zagreb) 2012;22:63-75. doi:10.11613/BM.2012.007pmid:22384520.

16 Alvarez-Lario B, Macarrón-Vicente $\mathrm{J}$. Is there anything good in uric acid?QJM 2011;104:1015-24. doi:10.1093/qjmed/hcr159pmid:21908382

17 DerSimonian R, Laird N. Meta-analysis in clinical trials. Control Clin Trials 1986;7:177-88. doi:10.1016/0197-2456(86)90046-2pmid:3802833.

18 Higgins JP, Thompson SG, Spiegelhalter DJ. A re-evaluation of random-effects meta-analysis. J R Stat Soc Ser A Stat Soc 2009;172:137-59. doi:10.1111/j.1467-985X. 2008.00552.xpmid:19381330

19 Higgins JP. Commentary: Heterogeneity in meta-analysis should be expected and appropriately quantified. Int J Epidemiol 2008;37:1158-60. doi:10.1093/ije/dyn204pmid: 18832388.

20 Egger M, Davey Smith G, Schneider M, Minder C. Bias in meta-analysis detected by a simple, graphical test. BMJ 1997;315:629-34. doi:10.1136/bmj.315.7109.629pmid:9310563.

21 loannidis JP. Excess significance bias in the literature on brain volume abnormalities. Arch Gen Psychiatry 2011;68:773-80. doi:10.1001/archgenpsychiatry.2011.28pmid: 21464342.

22 Ioannidis JP, Trikalinos TA. An exploratory test for an excess of significant findings. Clin Trials 2007:4:245-53. doi:10.1177/1740774507079441pmid:17715249.

23 Ioannidis JPA. Clarifications on the application and interpretation of the test for excess significance and its extensions. J Math Psychol 2013;57:184-7doi:10.1016/j.jmp.2013.03. 002.

24 Chinn S. A simple method for converting an odds ratio to effect size for use in meta-analysis. Stat Med 2000;19:3127-31. doi:10.1002/1097-0258(20001130)19:22<3127: :AID-SIM784>3.0.CO;2-Mpmid:11113947.

25 Brion MJ, Shakhbazov K, Visscher PM. Calculating statistical power in Mendelian randomization studies. Int J Epidemiol 2013;42:1497-501. doi:10.1093/ije/dyt179pmid: 24159078.

26 Bellou V, Belbasis L, Tzoulaki I, Evangelou E, loannidis JP. Environmental risk factors and Parkinson's disease: An umbrella review of meta-analyses. Parkinsonism Relat Disord 2016;23:1-9. doi:10.1016/j.parkreldis.2015.12.008pmid:26739246.

27 Kavanagh BP. The GRADE system for rating clinical guidelines. PLoS Med 2009;6:e1000094. doi:10.1371/journal.pmed.1000094pmid:19753107.

28 Pierce BL, Ahsan H, Vanderweele TJ. Power and instrument strength requirements for Mendelian randomization studies using multiple genetic variants. Int J Epidemiol 2011;40:740-52. doi:10.1093/ije/dyq151pmid:20813862.

29 Baker JF, Krishnan E, Chen L, Schumacher HR. Serum uric acid and cardiovascular disease: recent developments, and where do they leave us? Am J Med 2005;118:816-26. doi:10.1016/j.amjmed.2005.03.043pmid:16084170.

30 Strazzullo P, Puig JG. Uric acid and oxidative stress: relative impact on cardiovascular risk? Nutr Metab Cardiovasc Dis 2007;17:409-14. doi:10.1016/..numecd.2007.02.011pmid: 17643880 .

31 Barron E, Lara J, White M, Mathers JC. Blood-borne biomarkers of mortality risk: systematic review of cohort studies. PLoS One 2015;10:e0127550. doi:10.1371/journal. pone.0127550pmid:26039142.

32 Dimitroula $\mathrm{HV}$, Hatzitolios Al, Karvounis $\mathrm{HI}$. The role of uric acid in stroke: the issue remains unresolved. Neurologist 2008;14:238-42. doi:10.1097/NRL. 0b013e31815c666bpmid:18617849.

$33 \mathrm{Hwu}$ CM, Lin KH. Uric acid and the development of hypertension. Med Sci Monit 2010;16:RA224-30.pmid:20885365.

34 Avram Z, Krishnan E. Hyperuricaemia--where nephrology meets rheumatology. Rheumatology (Oxford) 2008;47:960-4. doi:10.1093/rheumatology/ken070pmid:18443007.

35 Feig DI. Uric acid: a novel mediator and marker of risk in chronic kidney disease? Curr Opin Nephrol Hypertens 2009;18:526-30. doi:10.1097/MNH.0b013e328330d9d0pmid: 19654543.

36 Alonso A, Sovell KA. Gout, hyperuricemia, and Parkinson's disease: a protective effect? Curr Rheumatol Rep 2010;12:149-55. doi:10.1007/s11926-010-0083-4pmid: 20425025.

37 Chang YT, Chang WN, Tsai NW, et al. The roles of biomarkers of oxidative stress and antioxidant in Alzheimer's disease: a systematic review. Biomed Res Int 2014;2014:182303. doi:10.1155/2014/182303pmid:24949424.

38 Cnossen JS, de Ruyter-Hanhijärvi $\mathrm{H}$, van der Post JA, Mol BW, Khan KS, ter Riet G. Accuracy of serum uric acid determination in predicting pre-eclampsia: a systematic review. Acta Obstet Gynecol Scand 2006;85:519-25. doi:10.1080/ 00016340500342037 pmid: 16755708

39 Zhang CH, Huang DS, Shen D, et al. Association Between Serum Uric Acid Levels and Atrial Fibrillation Risk. Cell Physiol Biochem 2016;38:1589-95. doi:10.1159/000443099pmid: 27082929.

40 Zhao J, Liu T, Korantzopoulos $\mathrm{P}$, et al. Association between serum uric acid and atrial fibrillation recurrence following catheter ablation: A meta-analysis. Int $J$ Cardiol 2016;204:103-5. doi:10.1016/j.ijcard.2015.11.167pmid:26655551.

$41 \mathrm{Li} \mathrm{M,} \mathrm{Hu} \mathrm{X,} \mathrm{Fan} \mathrm{Y,} \mathrm{et} \mathrm{al.} \mathrm{Hyperuricemia} \mathrm{and} \mathrm{the} \mathrm{risk} \mathrm{for} \mathrm{coronary} \mathrm{heart} \mathrm{disease} \mathrm{morbidity}$ and mortality a systematic review and dose-response meta-analysis. Sci Rep 2016:6:19520. doi:10.1038/srep19520pmid:26814153.

42 Qin T, Zhou X, Wang J, et al. Hyperuricemia and the Prognosis of Hypertensive Patients: A Systematic Review and Meta-Analysis. J Clin Hypertens (Greenwich) 2016;18:1268-78. doi:10.1111/jch.12855pmid:27247021

43 Huang $\mathrm{H}$, Huang B, Li Y, et al. Uric acid and risk of heart failure: a systematic review and meta-analysis. Eur J Heart Fail 2014;16:15-24. doi:10.1093/eurihf/hft132pmid:23933579.

44 Wang J, Qin T, Chen J, et al. Hyperuricemia and risk of incident hypertension: a systematic review and meta-analysis of observational studies. PLoS One 2014;9:e114259. doi:10. 1371/journal.pone.0114259pmid:25437867.

45 Jiang M, Gong D, Fan Y. Serum uric acid levels and risk of prehypertension: a meta-analysis. Clin Chem Lab Med 2016.pmid:27343474.

46 Song $\mathrm{X}$, Wang $\mathrm{Y}$, Hou $\mathrm{X}$, et al. Association between hyperuricemia and clinical adverse outcomes after percutaneous coronary intervention: A meta-analysis. Int $J$ Cardiol 2015;201:658-62. doi:10.1016/j.jijcard.2015.07.074pmid:26363629. 


\section{What is already known on this topic}

Observational studies suggest that high serum uric acid (SUA) levels are associated with multiple health outcomes, including cardiovascular and metabolic diseases (increased risk) or neurological diseases (decreased risk), yet it remains to be determined whether these observed associations are causal

Clinical trials of SUA lowering have shown that xanthine oxidase inhibition decreases blood pressure and improves renal function There is still debate as to whether SUA level is simply a marker of xanthine oxidase activity or a causal factor involved in systemic inflammation

\section{What this study adds}

Of the 136 health outcomes related to SUA level that were examined in meta-analyses of observational studies, meta-analyses of randomised controlled trials, and Mendelian randomisation studies, convincing evidence of a clear association exists only for gout and nephrolithiasis

The available evidence does not support any change in the existing clinical recommendations in relation to hyperuricemia

47 Trkulja V, Car S. On-admission serum uric acid predicts outcomes after acute myocardial infarction: systematic review and meta-analysis of prognostic studies. Croat Med $\mathrm{J}$ 2012;53:162-72. doi:10.3325/cmj.2012.53.162pmid:22522995

48 Li M, Hou W, Zhang X, Hu L, Tang Z. Hyperuricemia and risk of stroke: a systematic review and meta-analysis of prospective studies. Atherosclerosis 2014;232:265-70. doi: 10.1016/j.atherosclerosis.2013.11.051pmid:24468137

49 Kodama S, Saito K, Yachi Y, et al. Association between serum uric acid and development of type 2 diabetes. Diabetes Care 2009;32:1737-42. doi:10.2337/dc09-0288pmid:19549729.

50 Jia Z, Zhang X, Kang S, Wu Y. Serum uric acid levels and incidence of impaired fasting glucose and type 2 diabetes mellitus: a meta-analysis of cohort studies. Diabetes Res Clin Pract 2013;101:88-96. doi:10.1016/..diabres.2013.03.026pmid:23608549.

$51 \mathrm{Xu} \mathrm{Y,} \mathrm{Zhu} \mathrm{J,} \mathrm{Gao} \mathrm{L,} \mathrm{et} \mathrm{al.} \mathrm{Hyperuricemia} \mathrm{as} \mathrm{an} \mathrm{independent} \mathrm{predictor} \mathrm{of} \mathrm{vascular}$ complications and mortality in type 2 diabetes patients: a meta-analysis. PLOS One 2013;8:e78206. doi:10.1371/journal.pone.0078206pmid:24205159

$52 \mathrm{Xu} \mathrm{X}$, Du N, Wang R, Wang Y, Cai S. Hyperuricemia is independently associated with increased risk of atrial fibrillation: A meta-analysis of cohort studies. Int $\mathrm{J}$ Cardio 2015;184:699-702. doi:10.1016/.j.jcard.2015.02.038pmid:25777070.

53 Yu S, Chen Y, Hou X, et al. Serum Uric Acid Levels and Diabetic Peripheral Neuropathy in Type 2 Diabetes: a Systematic Review and Meta-analysis. Mol Neurobio 2016;53:1045-51. doi:10.1007/s12035-014-9075-0pmid:25579387.

54 Zhu P, Liu Y, Han L, Xu G, Ran JM. Serum uric acid is associated with incident chronic kidney disease in middle-aged populations: a meta-analysis of 15 cohort studies. PLOS One 2014:9:e100801. doi:10.1371/journal.pone.0100801pmid:24959886.

55 Li L, Yang C, Zhao Y, Zeng X, Liu F, Fu P. Is hyperuricemia an independent risk factor for new-onset chronic kidney disease?: A systematic review and meta-analysis based on observational cohort studies. BMC Nephrol 2014;15:122. doi:10.1186/1471-2369-15122pmid:25064611.

56 Huang Y, Li YL, Huang H, Wang L, Yuan WM, Li J. Effects of hyperuricemia on renal function of renal transplant recipients: a systematic review and meta-analysis of cohort studies. PLoS One 2012;7:e39457. doi:10.1371/journal.pone.0039457pmid:22745759.

57 Du N, Xu D, Hou X, et al. Inverse Association Between Serum Uric Acid Levels and Alzheimer's Disease Risk. Mol Neurobiol 2016;53:2594-9. doi:10.1007/s12035-015-9271 6pmid:26084440.

58 Khan A. T JQ, Dawson J. Serum uric acid level and cognitive function; A systematic review and meta-analysis. Cerebrovasc Dis 2013;35:821.

59 Shen C, Guo Y, Luo W, Lin C, Ding M. Serum urate and the risk of Parkinson's disease: results from a meta-analysis. Can J Neurol Sci 2013;40:73-9. doi:10.1017/ S0317167100012981pmid:23250131.

60 Wang L, Hu W, Wang J, Qian W, Xiao H. Low serum uric acid levels in patients with multiple sclerosis and neuromyelitis optica: An updated meta-analysis. Mult Scler Relat Disord 2016:9:17-22. doi:10.1016/j.msard.2016.05.008pmid:27645338.

61 Abraham A, Drory VE. Influence of serum uric acid levels on prognosis and survival in amyotrophic lateral sclerosis: a meta-analysis. J Neurol 2014;261:1133-8. doi:10.1007/ s00415-014-7331-xpmid:24699859.

62 Flatow J, Buckley P, Miller BJ. Meta-analysis of oxidative stress in schizophrenia. Biol Psychiatry 2013;74:400-9. doi:10.1016/..biopsych.2013.03.018pmid:23683390.

63 Bartoli F, Crocamo C, Mazza MG, Clerici M, Carrà G. Uric acid levels in subjects with bipolar disorder: A comparative meta-analysis. J Psychiatr Res 2016;81:133-9. doi:10. 1016/j.jpsychires.2016.07.007pmid:27442964.

64 Yan S, Zhang P, Xu W, et al. Serum Uric Acid Increases Risk of Cancer Incidence and Mortality: A Systematic Review and Meta-Analysis. Mediators Inflamm 2015;2015:764250 doi:10.1155/2015/764250pmid:26504361.

65 Zhao G. Baseline serum uric acid level as a predictor of cardiovascular disease related mortality and all-cause mortality: A meta-analysis of prospective studies. Cardiology (Switzerland) 2014;129:47.

66 Xia X, Luo Q, Li B, Lin Z, Yu X, Huang F. Serum uric acid and mortality in chronic kidney disease: A systematic review and meta-analysis. Metabolism 2016;65:1326-41. doi:10. 1016/j.metabol.2016.05.009pmid:27506740.

67 Tamariz L, Harzand A, Verma S, Jones J, Hare J. Uric acid as a predictor of mortality in congestive heart failure: A meta-analysis. J Am Coll Cardiol 2009;53:A169.

68 Yan L, Liu Z, Zhang C. Uric acid as a predictor of in-hospital mortality in acute myocardial infarction: a meta-analysis. Cell Biochem Biophys 2014;70:1597-601. doi:10.1007/s12013 014-0101-7pmid:25015064

69 Wang Z, Lin Y, Liu Y, et al. Serum Uric Acid Levels and Outcomes After Acute Ischemic Stroke. Mol Neurobiol 2016;53:1753-9. doi:10.1007/s12035-015-9134-1pmid:25744569.

70 Li X, Miao X, Wang H, et al. Association of Serum Uric Acid Levels in Psoriasis: A Systematic Review and Meta-Analysis. Medicine (Baltimore) 2016;95:e3676. doi:10.1097/ MD.0000000000003676pmid:27175702

71 Zhou Y, Wei F, Fan Y. High serum uric acid and risk of nonalcoholic fatty liver disease: A systematic review and meta-analysis. Clin Biochem 2016;49:636-42. doi:10.1016/ clinbiochem.2015.12.010pmid:26738417.

72 Braga F, Pasqualetti S, Ferraro S, Panteghini M. Hyperuricemia (HUA) as an independen risk factor for coronary heart disease $(\mathrm{CHD})$ in the general population: A systematic review and meta-analysis. . Clin Chem Lab Med 2015;53:S1199.
73 Chen X, Guo X, Huang R, Chen $Y$, Zheng Z, Shang $H$. Serum uric acid levels in patients with Alzheimer's disease: a meta-analysis. PLoS One 2014;9:e94084. doi:10.1371/journal. pone.0094084pmid:24714617.

74 Grayson PC, Kim SY, LaValley M, Choi HK. Hyperuricemia and incident hypertension: a systematic review and meta-analysis. Arthritis Care Res (Hoboken) 2011;63:102-10. doi: 10.1002/acr.20344pmid:20824805

75 Kim SY, Guevara JP, Kim KM, Choi HK, Heitjan DF, Albert DA. Hyperuricemia and risk of stroke: a systematic review and meta-analysis. Arthritis Rheum 2009;61:885-92. doi: 10.1002/art.24612pmid:19565556

76 Kim SY, Guevara JP, Kim KM, Choi HK, Heitjan DF, Albert DA. Hyperuricemia and coronary heart disease: a systematic review and meta-analysis. Arthritis Care Res (Hoboken) 2010;62:170-80.pmid:20191515.

77 Li YL, Wang L, Li J, Huang Y, Yuan WM. [The correlation between uric acid and the incidence and prognosis of kidney diseases: a systematic review and meta-analysis of cohort studies]. Zhonghua Nei Ke Za Zhi 2011;50:555-61.pmid:22041264.

78 Liu B, Shen Y, Xiao K, Tang Y, Cen L, Wei J. Serum uric acid levels in patients with multiple sclerosis: a meta-analysis. Neurol Res 2012;34:163-71.pmid:22333889.

79 Lv Q, Meng XF, He FF, et al. High serum uric acid and increased risk of type 2 diabetes: a systemic review and meta-analysis of prospective cohort studies. PLoS One 2013;8:e56864. doi:10.1371/journal.pone.0056864pmid:23437258.

80 Schrag M, Mueller C, Zabel M, et al. Oxidative stress in blood in Alzheimer's disease and mild cognitive impairment: a meta-analysis. Neurobiol Dis 2013;59:100-10. doi:10.1016/ j.nbd.2013.07.005pmid:23867235.

81 Shen L, Ji HF. Low uric acid levels in patients with Parkinson's disease: evidence from meta-analysis. BMJ Open 2013;3:e003620. doi:10.1136/bmjopen-2013-003620pmid: 24247326.

82 Tamariz L, Hernandez F, Bush A, Palacio A, Hare JM. Association between serum uric acid and atrial fibrillation: a systematic review and meta-analysis. Heart Rhythm 2014:11:1102-8. doi:10.1016/j.hrthm.2014.04.003pmid:24709288.

83 Wheeler JG, Juzwishin KDM, Eiriksdottir G, Gudnason V, Danesh J. Serum uric acid and coronary heart disease in 9,458 incident cases and 155084 controls: Prospective study and meta-analysis. PLoS Med 2005;2(3):0236-43.

84 Yang $\mathrm{Y}$, Fan $\mathrm{Y}$, Li J, et al. Serum uric acid as a predictor for cardiovascular and all-cause mortality in women versus men. Int J Cardiol 2015;185:125-8. doi:10.1016/j.ijcard.2015. 03.121pmid:25791110.

85 Zhang W, Sun K, Yang Y, Zhang H, Hu FB, Hui R. Plasma uric acid and hypertension in a Chinese community: prospective study and metaanalysis. Clin Chem 2009;55:2026-34. doi:10.1373/clinchem.2009.124891pmid:19729471

86 Fink HA, Wilt TJ, Eidman KE, et al. Medical management to prevent recurrent nephrolithiasis in adults: a systematic review for an American College of Physicians Clinical Guideline. Ann Intern Med 2013;158:535-43. doi:10.7326/0003-4819-158-7201304020-00005pmid:23546565.

87 Wang $\mathrm{H}$, Wei $\mathrm{Y}$, Kong $\mathrm{X}, \mathrm{Xu} \mathrm{D}$. Effects of urate-lowering therapy in hyperuricemia on slowing the progression of renal function: a meta-analysis. J Ren Nutr 2013;23:389-96. doi:10.1053/j.jn.2012.08.005pmid:23131573.

88 Zhang YF, He F, Ding HH, et al. Effect of uric-acid-lowering therapy on progression of chronic kidney disease: a meta-analysis. J Huazhong Univ Sci Technolog Med Sci 2014:34:476-81. doi:10.1007/s11596-014-1302-4pmid:25135714.

89 Bose B, Badve SV, Hiremath SS, et al. Effects of uric acid-lowering therapy on renal outcomes: a systematic review and meta-analysis. Nephrol Dial Transplant 2014;29:406-13. doi:10.1093/ndt/gft378pmid:24042021.

90 Higgins P, Dawson J, Lees KR, McArthur K, Quinn TJ, Walters MR. Xanthine oxidase inhibition for the treatment of cerebrovascular and cardiovascular disease: A systematic review and meta-analysis. Cerebrovasc Dis 2010:29:321.pmid:20130397.

91 Kanbay M, Siriopol D, Nistor I, et al. Effects of allopurinol on endothelial dysfunction: a meta-analysis. Am J Nephrol 2014;39:348-56. doi:10.1159/000360609pmid:24751886.

92 Chaudhari T, McGuire W. Allopurinol for preventing mortality and morbidity in newborn infants with hypoxic-ischaemic encephalopathy. Cochrane Database Syst Rev 2012:(7):CD006817. doi:10.1002/14651858.CD006817.pub3

93 Agarwal V, Hans N, Messerli FH. Effect of allopurinol on blood pressure: a systematic review and meta-analysis. J Clin Hypertens (Greenwich) 2013;15:435-42. doi:10.1111/j. 1751-7176.2012.00701.xpmid:23730993

94 Korostishevsky M, Steves CJ, Malkin I, Spector T, Williams FM, Livshits G. Genomics and metabolomics of muscular mass in a community-based sample of UK females. Eur J Hum Genet 2016;24:277-83. doi:10.1038/ejhg.2015.85pmid:25898920.

95 Lyngdoh T, Vuistiner P, Marques-Vidal P, et al. Serum uric acid and adiposity: deciphering causality using a bidirectional Mendelian randomization approach. PLoS One 2012;7:e39321. doi:10.1371/journal.pone.0039321pmid:22723994.

96 White J, Sofat R, Hemani G, et al. International Consortium for Blood Pressure (ICBP) UCLEB (University College London-London School of Hygiene \& Tropical Medicine-Edinburgh-Bristol Consortium. Plasma urate concentration and risk of coronary heart disease: a Mendelian randomisation analysis. Lancet Diabetes Endocrinol 2016;4:327-36. doi:10.1016/S2213-8587(15)00386-1 pmid:26781229. 
97 Dalbeth N, Topless R, Flynn T, Cadzow M, Bolland MJ, Merriman TR. Mendelian randomization analysis to examine for a causal effect of urate on bone mineral density. J Bone Miner Res 2015;30:985-91. doi:10.1002/jbmr.2434pmid:25502344.

98 Xiong A, Yao Q, He J, Fu W, Yu J, Zhang Z. No causal effect of serum urate on bone-related outcomes among a population of postmenopausal women and elderly men of Chinese Han ethnicity--a Mendelian randomization study. Osteoporos Int 2016;27:1031-9. doi:10.1007/s00198-015-3341-5pmid:26588908.

99 Kleber ME, Delgado G, Grammer TB, et al. Uric Acid and Cardiovascular Events: A Mendelian Randomization Study. J Am Soc Nephrol 2015;26:2831-8. doi:10.1681/ASN. 2014070660pmid:25788527.

100 Keenan T, Zhao W, Rasheed A, et al. Causal Assessment of Serum Urate Levels in Cardiometabolic Diseases Through a Mendelian Randomization Study. J Am Coll Cardiol 2016;67:407-16. doi:10.1016/.jacc.2015.10.086pmid:26821629.

101 Palmer TM, Nordestgaard BG, Benn M, et al. Association of plasma uric acid with ischaemic heart disease and blood pressure: mendelian randomisation analysis of two large cohorts. BMJ 2013;347:f4262. doi:10.1136/bmj.f4262pmid:23869090.

102 Oikonen M, Wendelin-Saarenhovi M, Lyytikäinen LP, et al. Associations between serum uric acid and markers of subclinical atherosclerosis in young adults. The cardiovascular risk in Young Finns study. Atherosclerosis 2012;223:497-503. doi:10.1016/j.atherosclerosis. 2012.05.036pmid:22749515.

103 Yan D, Wang J, Jiang F, et al. A causal relationship between uric acid and diabetic macrovascular disease in Chinese type 2 diabetes patients: A Mendelian randomization analysis. Int J Cardiol 2016;214:194-9. doi:10.1016/j.ijcard.2016.03.206pmid:27064641.

104 Mallamaci F, Testa A, Leonardis D, et al. A genetic marker of uric acid level, carotid atherosclerosis, and arterial stiffness: a family-based study. Am J Kidney Dis 2015:65:294-302. doi:10.1053/i.ajkd.2014.07.021pmid:25301104

105 Sluijs I, Holmes MV, van der Schouw YT, et al. InterAct Consortium. A Mendelian Randomization Study of Circulating Uric Acid and Type 2 Diabetes. Diabetes 2015;64:3028-36. doi:10.2337/db14-0742pmid:25918230.

106 Yang Q, Köttgen A, Dehghan A, et al. Multiple genetic loci influence serum urate levels and their relationship with gout and cardiovascular disease risk factors. Circ Cardiovasc Genet 2010;3:523-30. doi:10.1161/CIRCGENETICS.109.934455pmid:20884846.

107 Dai X, Yuan J, Yao P, et al. Association between serum uric acid and the metabolic syndrome among a middle- and old-age Chinese population. Eur J Epidemiol 2013;28:669-76. doi:10.1007/s10654-013-9829-4pmid:23864233.

108 Greenberg KI, McAdams-DeMarco MA, Köttgen A, Appel LJ, Coresh J, Grams ME. Plasma Urate and Risk of a Hospital Stay with AKI: The Atherosclerosis Risk in Communities Study. Clin J Am Soc Nephrol2015;10:776-83. doi:10.2215/CJN.05870614pmid:25717072.

109 Testa A, Mallamaci F, Spoto B, et al. Association of a polymorphism in a gene encoding a urate transporter with CKD progression. Clin J Am Soc Nephrol 2014;9:1059-65. doi: 10.2215/CJN.11041013pmid:24742479.

110 Hughes K, Flynn T, de Zoysa J, Dalbeth N, Merriman TR. Mendelian randomization analysis associates increased serum urate, due to genetic variation in uric acid transporters, with improved renal function. Kidney Int 2014;85:344-51. doi:10.1038/ki. 2013.353pmid:24048376

111 Gao J, Xu H, Huang X, Chen H. Short communication: genetic variations of SLC2A9 in relation to Parkinson's disease. Trans/ Neurodegener 2013;2:5. doi:10.1186/2047-91582-5pmid:23422251.

112 Facheris MF, Hicks AA, Minelli C, et al. Variation in the uric acid transporter gene SLC2A9 and its association with AAO of Parkinson's disease. J Mol Neurosci 2011;43:246-50. doi:10.1007/s12031-010-9409-ypmid:20589538.

113 Lyngdoh T, Bochud M, Glaus J, et al. Associations of serum uric acid and SLC2A9 variant with depressive and anxiety disorders: a population-based study. PLOS One 2013;8:e76336. doi:10.1371/journal.pone.0076336pmid:24204615

114 Houlihan LM, Wyatt ND, Harris SE, et al. Variation in the uric acid transporter gene (SLC2A9) and memory performance. Hum Mol Genet 2010;19:2321-30. doi:10.1093/hmg/ ddq097pmid:20197412.

115 Burgess S, Daniel RM, Butterworth AS, Thompson SG. EPIC-InterAct Consortium. Network Mendelian randomization: using genetic variants as instrumental variables to investigate mediation in causal pathways. Int J Epidemiol 2015;44:484-95. doi:10.1093/jij/dyu176pmid: 25150977.

116 González-Aramburu I, Sánchez-Juan P, Jesús S, et al. Genetic variability related to serum uric acid concentration and risk of Parkinson's disease. Mov Disord 2013;28:1737-40. doi:10.1002/mds.25507pmid:23712608

117 González-Aramburu I, Sánchez-Juan P, Sierra M, et al. Serum uric acid and risk of dementia in Parkinson's disease. Parkinsonism Relat Disord 2014;20:637-9. doi:10.1016 j.parkreldis.2014.02.023pmid:24637121.

118 Han X, Gui L, Liu B, et al. Associations of the uric acid related genetic variants in SLC2A9 and ABCG2 loci with coronary heart disease risk. BMC Genet 2015;16:4. doi:10.1186/ s12863-015-0162-7pmid:25634581.

119 Mallamaci F, Testa A, Leonardis D, et al. A polymorphism in the major gene regulating serum uric acid associates with clinic SBP and the white-coat effect in a family-based study. J Hypertens 2014;32:1621-8, discussion 1628. doi:10.1097/HJH. $0000000000000224 \mathrm{pmid}: 24805955$.

120 McKeigue PM, Campbell H, Wild S, et al. Bayesian methods for instrumental variable analysis with genetic instruments ('Mendelian randomization'): example with urate transporter SLC2A9 as an instrumental variable for effect of urate levels on metabolic syndrome. Int J Epidemiol 2010;39:907-18. doi:10.1093/ije/dyp397pmid:20348110.

121 Parsa A, Brown E, Weir MR, et al. Genotype-based changes in serum uric acid affec blood pressure. Kidney Int 2012;81:502-7. doi:10.1038/ki.2011.414pmid:22189840.

122 Pfister R, Barnes D, Luben R, et al. No evidence for a causal link between uric acid and type 2 diabetes: a Mendelian randomisation approach. Diabetologia 2011;54:2561-9. doi: 10.1007/s00125-011-2235-0pmid:21717115.

123 Rasheed H, Hughes K, Flynn TJ, Merriman TR. Mendelian randomization provides no evidence for a causal role of serum urate in increasing serum triglyceride levels. Circ Cardiovasc Genet2014;7:830-7. doi:10.1161/CIRCGENETICS.114.000556pmid:25249548.
124 Sedaghat S, Pazoki R, Uitterlinden AG, et al. Association of uric acid genetic risk score with blood pressure: the Rotterdam study. Hypertension 2014;64:1061-6. doi:10.1161/ HYPERTENSIONAHA.114.03757pmid.25185132.

125 Simon KC, Eberly S, Gao X, et al. Parkinson Study Group. Mendelian randomization of serum urate and parkinson disease progression. Ann Neurol 2014;76:862-8. doi:10.1002 ana.24281pmid:25257975

126 Stark K, Reinhard W, GrassI M, et al. Common polymorphisms influencing serum uric acid levels contribute to susceptibility to gout, but not to coronary artery disease. PLOS One 2009;4:e7729. doi:10.1371/journal.pone.0007729pmid:19890391.

127 Sun X, Zhang R, Jiang F, et al. Common variants related to serum uric acid concentrations are associated with glucose metabolism and insulin secretion in a Chinese population. PLoS One 2015;10:e0116714. doi:10.1371/journal.pone.0116714pmid:25617895.

128 Tabara Y, Kohara K, Kawamoto R, et al. Association of four genetic loci with uric acid levels and reduced renal function: the J-SHIPP Suita study. Am J Nephrol 2010;32:279-86. doi:10.1159/000318943pmid:20714133.

129 Voruganti VS, Franceschini N, Haack K, et al. Replication of the effect of SLC2A9 genetic variation on serum uric acid levels in American Indians. Eur J Hum Genet 2014;22:938-43. doi:10.1038/ejhg.2013.264pmid:24301058

130 Holme I, Aastveit AH, Hammar N, Jungner I, Walldius G. Uric acid and risk of myocardial infarction, stroke and congestive heart failure in 417,734 men and women in the Apolipoprotein MOrtality RISk study (AMORIS). J Intern Med 2009;266:558-70. doi:10. 1111/j.1365-2796.2009.02133.xpmid:19563390.

131 Mazza A, Pessina AC, Pavei A, Scarpa R, Tikhonoff V, Casiglia E. Predictors of stroke mortality in elderly people from the general population. The CArdiovascular STudy in the ELderly. Eur J Epidemiol 2001;17:1097-104. doi:10.1023/A:1021216713504pmid: 12530768.

132 Kuo CF, See LC, Yu KH, Chou IJ, Chiou MJ, Luo SF. Significance of serum uric acid levels on the risk of all-cause and cardiovascular mortality. Rheumatology (Oxford) 2013;52:127-34. doi:10.1093/rheumatology/kes223pmid:22923756.

133 Chen JH, Chuang SY, Chen HJ, Yeh WT, Pan WH. Serum uric acid level as an independent risk factor for all-cause, cardiovascular, and ischemic stroke mortality: a Chinese cohort study. Arthritis Rheum 2009;61:225-32. doi:10.1002/art.24164pmid: 19177541.

134 Owens DK, Lohr KN, Atkins D, et al. AHRQ series paper 5: grading the strength of a body of evidence when comparing medical interventions--agency for healthcare research and quality and the effective health-care program. J Clin Epidemiol 2010;63:513-23. doi:10. 1016/j.jclinepi.2009.03.009pmid:19595577.

135 Theodoratou E, Tzoulaki I, Zgaga L, loannidis JP. Vitamin D and multiple health outcomes: umbrella review of systematic reviews and meta-analyses of observational studies and randomised trials. BMJ 2014;348:g2035. doi:10.1136/bmj.g2035pmid:24690624.

136 Belbasis L, Savvidou MD, Kanu C, Evangelou E, Tzoulaki I. Birth weight in relation to health and disease in later life: an umbrella review of systematic reviews and meta-analyses. BMC Med 2016;14:147. doi:10.1186/s12916-016-0692-5pmid:27677312.

37 Krishnan E, Lessov-Schlaggar CN, Krasnow RE, Swan GE. Nature versus nurture in gout: a twin study. Am J Med 2012;125:499-504. doi:10.1016/i.amjmed.2011.11.010pmid: 22365026 .

138 Köttgen A, Albrecht E, Teumer A, et al. LifeLines Cohort Study CARDloGRAM Consortium DIAGRAM Consortium ICBP Consortium MAGIC Consortium. Genome-wide association analyses identify 18 new loci associated with serum urate concentrations. Nat Genet 2013:45:145-54. doi:10.1038/ng.2500pmid:23263486.

139 Richette P, Doherty M, Pascual E, et al. 2016 updated EULAR evidence-based recommendations for the management of gout. Ann Rheum Dis 2017;76:29-42. doi:10. 1136/annrheumdis-2016-209707pmid:27457514

140 Chen H, Mosley TH, Alonso A, Huang X. Plasma urate and Parkinson's disease in the Atherosclerosis Risk in Communities (ARIC) study. Am J Epidemiol 2009;169:1064-9. doi:10.1093/aje/kwp033pmid:19299404.

141 Weisskopf MG, O'Reilly E, Chen H, Schwarzschild MA, Ascherio A. Plasma urate and risk of Parkinson's disease. Am J Epidemio/2007;166:561-7. doi:10.1093/aje/kwm127pmid: 17584757.

$142 \mathrm{Kim} \mathrm{TS}, \mathrm{Pae} \mathrm{CU}$, Yoon SJ, et al. Decreased plasma antioxidants in patients with Alzheimer's disease. Int J Geriatr Psychiatry 2006;21:344-8. doi:10.1002/gps.1469pmid: 16534775.

143 Feig DI, Madero M, Jalal DI, Sanchez-Lozada LG, Johnson RJ. Uric acid and the origins of hypertension. J Pediatr 2013;162:896-902. doi:10.1016/j.jpeds.2012.12.078pmid: 23403249.

44 Tamariz L, Hare JM. Xanthine oxidase inhibitors in heart failure: where do we go from here? Circulation 2015;131:1741-4. doi:10.1161/CIRCULATIONAHA.115.016379pmid: 25986446.

145 Ioannidis JP. The Mass Production of Redundant, Misleading, and Conflicted Systematic Reviews and Meta-analyses. Milbank Q 2016;94:485-514. doi:10.1111/1468-0009. 12210pmid:27620683.

146 Kavvoura FK, Liberopoulos G, loannidis JP. Selection in reported epidemiological risks: an empirical assessment. PLoS Med 2007;4:e79. doi:10.1371/journal.pmed.0040079pmid: 17341129.

147 loannidis JP. Exposure-wide epidemiology: revisiting Bradford Hill. Stat Med 2016;35:1749-62. doi:10.1002/sim.6825pmid:26646432.

Accepted: 10052017

Published by the BMJ Publishing Group Limited. For permission to use (where not already granted under a licence) please go to http://group.bmj.com/group/rights-licensing/ permissions

This is an Open Access article distributed in accordance with the Creative Commons Attribution Non Commercial (CC BY-NC 4.0) license, which permits others to distribute, remix, adapt, build upon this work non-commercially, and license their derivative works on different terms, provided the original work is properly cited and the use is non-commercial. See: http://creativecommons.org/licenses/by-nc/4.0/. 


\section{Tables}

Table 1| Health outcomes and evidence class reported in meta-analyses (MA) of observational studies

\begin{tabular}{|c|c|c|c|c|c|c|c|c|c|c|c|c|c|c|}
\hline Outcomes & Population & $\begin{array}{c}\text { Study design } \\
\text { included in } \\
\text { MA }\end{array}$ & Comparison & $\begin{array}{l}\text { No of } \\
\text { studies }\end{array}$ & $\begin{array}{c}\text { No of } \\
\text { participants }\end{array}$ & $\begin{array}{l}\text { No of } \\
\text { cases }\end{array}$ & $\begin{array}{l}\text { Type of } \\
\text { metric }\end{array}$ & $\begin{array}{l}\text { Relative } \\
\text { risk } \\
(95 \% \mathrm{Cl})\end{array}$ & $P$ value & $\begin{array}{c}I^{2} \\
(95 \% \\
\mathrm{Cl})\end{array}$ & $\begin{array}{c}P \\
\text { value } \\
\text { for } \\
\text { Egger } \\
\text { test }\end{array}$ & $\begin{array}{l}P \text { value for } \\
\text { excess } \\
\text { significance } \\
\text { test }\end{array}$ & $\begin{array}{c}95 \% \\
\text { prediction } \\
\text { interval }\end{array}$ & 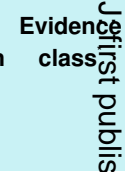 \\
\hline \multicolumn{15}{|c|}{ Cardiovascular outcomes } \\
\hline $\mathrm{AF}^{39}$ & General & $\begin{array}{l}\text { Prospective } \\
\text { cohort }\end{array}$ & $\begin{array}{l}\text { Hyper } v \\
\text { normal }\end{array}$ & 6 & 426159 & 7595 & $\mathrm{RR}$ & $\begin{array}{c}1.49 \\
(1.24 \text { to } \\
1.79)\end{array}$ & $2.50 \mathrm{E}-05$ & $\begin{array}{c}79 \\
(42 \\
\text { to } \\
89) \\
\end{array}$ & 0.01 & 0.22 & $\begin{array}{l}0.87 \text { to } \\
2.53\end{array}$ & III $\begin{array}{l}0 \\
\text { के } \\
\overrightarrow{0} \\
\ddot{\Xi}\end{array}$ \\
\hline AF recurrence $e^{40}$ & $\begin{array}{l}\text { Patients with } \\
\mathrm{AF}\end{array}$ & $\begin{array}{l}\text { Prospective or } \\
\text { retrospective } \\
\text { cohort }\end{array}$ & $\begin{array}{l}\text { Hyper } v \\
\text { normal }\end{array}$ & 4 & 1298 & 393 & OR & $\begin{array}{c}1.52 \\
(1.19 \text { to } \\
1.94)\end{array}$ & $8.25 \mathrm{E}-04$ & $\begin{array}{l}89 \\
(61 \\
\text { to } \\
95)\end{array}$ & 0.72 & 0.26 & $\begin{array}{l}0.27 \text { to } \\
7.01\end{array}$ & 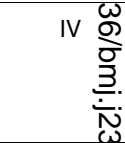 \\
\hline $\begin{array}{l}\text { Coronary heart } \\
\text { disease } \\
\text { incidence }^{41}\end{array}$ & General & $\begin{array}{l}\text { Prospective } \\
\text { cohort }\end{array}$ & $\begin{array}{l}\text { Hyper } v \\
\text { normal }\end{array}$ & 13 & 70382 & 6666 & aRR & $\begin{array}{c}1.13 \\
(1.05 \text { to } \\
1.21)\end{array}$ & 7.70E-04 & $\begin{array}{c}38(0 \\
\text { to } \\
64)\end{array}$ & 0.27 & $<0.001$ & $\begin{array}{c}0.94 \text { to } \\
1.34\end{array}$ & $\begin{array}{l}\text { III ने } \\
\text { 을 }\end{array}$ \\
\hline $\begin{array}{l}\text { Cardiovascular } \\
\text { disease }^{42}\end{array}$ & $\begin{array}{l}\text { Patients with } \\
\text { hypertension }\end{array}$ & $\begin{array}{l}\text { Prospective } \\
\text { cohort }\end{array}$ & $\begin{array}{l}\text { Hyper } v \\
\text { normal }\end{array}$ & 6 & 19546 & 1054 & aHR & $\begin{array}{c}1.17 \\
(1.07 \text { to } \\
1.27)\end{array}$ & $3.56 \mathrm{E}-04$ & $\begin{array}{l}67(0 \\
\text { to } \\
84)\end{array}$ & 0.05 & 0.04 & $\begin{array}{l}0.90 \text { to } \\
1.52\end{array}$ & \\
\hline $\begin{array}{l}\text { Heart failure } \\
\text { incidence }{ }^{43}\end{array}$ & General & $\begin{array}{l}\text { Prospective } \\
\text { cohort }\end{array}$ & $\begin{array}{l}\text { Hyper } v \\
\text { normal }\end{array}$ & 5 & 427917 & $\begin{array}{c}10 \\
171\end{array}$ & $\mathrm{HR}$ & $\begin{array}{c}1.65 \\
(1.41 \text { to } \\
1.94)\end{array}$ & $1.77 \mathrm{E}-09$ & $\begin{array}{c}72(7 \\
\text { to } \\
86)\end{array}$ & 0.49 & 0.31 & $\begin{array}{l}1.05 \text { to } \\
2.61\end{array}$ & \\
\hline $\begin{array}{l}\text { Hypertension } \\
\text { incidence }\end{array}$ & General & $\begin{array}{l}\text { Prospective } \\
\text { cohort or } \\
\text { nested } \\
\text { case-control }\end{array}$ & $\begin{array}{l}\text { Hyper } v \\
\text { normal }\end{array}$ & 17 & 71630 & $\begin{array}{c}18 \\
751\end{array}$ & aRR & $\begin{array}{c}1.48 \\
(1.33 \text { to } \\
1.65)\end{array}$ & $3.99 \mathrm{E}-12$ & $\begin{array}{c}79 \\
(65 \\
\text { to } \\
85)\end{array}$ & 0.06 & $\mathrm{NP}$ & $\begin{array}{l}0.99 \text { to } \\
2.23\end{array}$ & 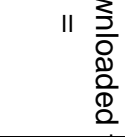 \\
\hline Prehypertension ${ }^{45}$ & General & $\begin{array}{l}\text { Cross } \\
\text { sectional }\end{array}$ & $\begin{array}{l}\text { Highest } v \\
\text { lowest SUA } \\
\text { category }\end{array}$ & 8 & 44095 & $\begin{array}{c}20 \\
832\end{array}$ & OR & $\begin{array}{c}1.84 \\
(1.42 \text { to } \\
2.38)\end{array}$ & $4.88 \mathrm{E}-06$ & $\begin{array}{c}91 \\
(86 \\
\text { to } \\
94)\end{array}$ & 0.10 & NP & $\begin{array}{l}0.81 \text { to } \\
4.01\end{array}$ & $\begin{array}{l}\text { III } \frac{\overrightarrow{0}}{3} \\
\frac{0}{3} \\
\text { 吾 } \\
\end{array}$ \\
\hline $\begin{array}{l}\text { Left atrial } \\
\text { thrombus or } \\
\text { spontaneous echo } \\
\text { contrast }^{39}\end{array}$ & $\begin{array}{l}\text { Patients with } \\
\text { heart } \\
\text { diseases }\end{array}$ & $\begin{array}{l}\text { Prospective or } \\
\text { retrospective } \\
\text { cohort }\end{array}$ & $\begin{array}{l}\text { Highest } v \\
\text { lowest SUA } \\
\text { category }\end{array}$ & 6 & 2381 & 241 & OR & $\begin{array}{c}1.59 \\
(1.13 \text { to } \\
2.23)\end{array}$ & $7.51 \mathrm{E}-03$ & $\begin{array}{l}85 \\
(66 \\
\text { to } \\
91)\end{array}$ & 0.02 & NP & $\begin{array}{c}0.54 \text { to } \\
4.70\end{array}$ & IV \\
\hline MACE $\dagger^{46}$ & $\begin{array}{l}\text { Patients after } \\
\mathrm{PCl}\end{array}$ & $\begin{array}{l}\text { Prospective or } \\
\text { retrospective } \\
\text { cohort }\end{array}$ & $\begin{array}{l}\text { Hyper } v \\
\text { normal }\end{array}$ & 2 & 3054 & NA & RR & $\begin{array}{c}1.78 \\
(1.26 \text { to } \\
2.52)\end{array}$ & $1.16 \mathrm{E}-03$ & NA & NA & NP & NA & IV $\frac{8}{3}$ \\
\hline $\begin{array}{l}\text { Medium term } \\
\text { MACE }^{47}\end{array}$ & $\begin{array}{l}\text { Patients with } \\
\text { AMI }\end{array}$ & $\begin{array}{l}\text { Prospectiveor } \\
\text { retrospective } \\
\text { cohort }\end{array}$ & $\begin{array}{l}\text { Highest } v \\
\text { lowest SUA } \\
\text { category }\end{array}$ & 4 & 4299 & 1240 & OR & $\begin{array}{c}1.93 \\
(1.36 \text { to } \\
2.74)\end{array}$ & $2.56 \mathrm{E}-04$ & $\begin{array}{c}74(0 \\
\text { to } \\
89)\end{array}$ & 0.81 & NP & $\begin{array}{c}0.46 \text { to } \\
8.21\end{array}$ & \\
\hline $\begin{array}{l}\text { Short term } \\
\text { MACE }^{47}\end{array}$ & $\begin{array}{l}\text { Patients with } \\
\text { AMI }\end{array}$ & $\begin{array}{l}\text { Prospective or } \\
\text { retrospective } \\
\text { cohort }\end{array}$ & $\begin{array}{l}\text { Highest } v \\
\text { lowest SUA } \\
\text { category }\end{array}$ & 7 & 6470 & 787 & OR & $\begin{array}{c}2.46 \\
(1.84 \text { to } \\
3.27)\end{array}$ & 1.93E-09 & $\begin{array}{l}63(0 \\
\text { to } \\
82)\end{array}$ & 0.25 & NP & $\begin{array}{c}1.06 \text { to } \\
5.71\end{array}$ & \\
\hline Stroke $^{42}$ & $\begin{array}{l}\text { Hypertensive } \\
\text { patients }\end{array}$ & $\begin{array}{l}\text { Prospective or } \\
\text { retrospective } \\
\text { cohort }\end{array}$ & $\begin{array}{l}\text { Continuous } \\
\text { SUA level }\end{array}$ & 3 & 9978 & 217 & aHR & $\begin{array}{c}1.11 \\
(0.98 \text { to } \\
1.26)\end{array}$ & 0.10 & $\begin{array}{c}70(0 \\
\text { to } \\
89)\end{array}$ & 0.22 & 0.06 & $\begin{array}{c}0.26 \text { to } \\
4.77\end{array}$ & 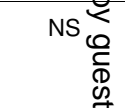 \\
\hline Stroke incidence ${ }^{48}$ & General & $\begin{array}{l}\text { Prospective } \\
\text { cohort }\end{array}$ & $\begin{array}{l}\text { Highest } v \\
\text { lowest SUA } \\
\text { category }\end{array}$ & 5 & 24548 & 1290 & aRR & $\begin{array}{c}1.22 \\
(1.02 \text { to } \\
1.46)\end{array}$ & 0.03 & $\begin{array}{c}53(0 \\
\text { to } \\
75) \\
\end{array}$ & 0.03 & NP & $\begin{array}{l}0.73 \text { to } \\
2.04\end{array}$ & IV $\frac{0}{0}$ \\
\hline \multicolumn{15}{|c|}{ Diabetes related outcomes } \\
\hline $\mathrm{T} 2 \mathrm{DM}^{49}$ & General & $\begin{array}{l}\text { Prospective or } \\
\text { retrospective } \\
\text { cohort }\end{array}$ & $\begin{array}{l}1 \mathrm{mg} / \mathrm{dL} \mathrm{SUA} \\
\text { increase }\end{array}$ & 11 & 42834 & 3305 & RR & $\begin{array}{c}1.17 \\
(1.09 \text { to } \\
1.25)\end{array}$ & 8.97E-06 & $\begin{array}{l}75 \\
(54 \\
\text { to } \\
84)\end{array}$ & 0.07 & 0.002 & $\begin{array}{c}0.92 \text { to } \\
1.47\end{array}$ & III \\
\hline $\begin{array}{l}\text { Impaired fasting } \\
\text { glucose or T2DM }\end{array}$ & General & $\begin{array}{l}\text { Prospective or } \\
\text { retrospective } \\
\text { cohort }\end{array}$ & $\begin{array}{l}\text { Highest } v \\
\text { lowest SUA } \\
\text { category }\end{array}$ & 12 & 62834 & 6340 & RR & $\begin{array}{c}1.57 \\
(1.39 \text { to } \\
1.77)\end{array}$ & $1.12 \mathrm{E}-12$ & $\begin{array}{l}42(0 \\
\text { to } \\
67)\end{array}$ & 0.09 & NP & $\begin{array}{l}1.10 \text { to } \\
2.23\end{array}$ & $\| \stackrel{\square}{?}$ \\
\hline
\end{tabular}


Table 1 (continued)

\begin{tabular}{|c|c|c|c|c|c|c|c|c|c|c|c|c|c|c|}
\hline Outcomes & Population & $\begin{array}{c}\text { Study design } \\
\text { included in } \\
\text { MA }\end{array}$ & Comparison & $\begin{array}{c}\text { No of } \\
\text { studies }\end{array}$ & $\begin{array}{c}\text { No of } \\
\text { participants }\end{array}$ & $\begin{array}{l}\text { No of } \\
\text { cases }\end{array}$ & $\begin{array}{l}\text { Type of } \\
\text { metric }\end{array}$ & $\begin{array}{c}\text { Relative } \\
\text { risk } \\
(95 \% \mathrm{Cl})\end{array}$ & $P$ value & $\begin{array}{c}I^{2} \\
(95 \% \\
\mathrm{CI})\end{array}$ & $\begin{array}{c}P \\
\text { value } \\
\text { for } \\
\text { Egger } \\
\text { test }\end{array}$ & $\begin{array}{l}\text { P value for } \\
\text { excess } \\
\text { significance } \\
\text { test }\end{array}$ & $\begin{array}{c}95 \% \\
\text { prediction } \\
\text { interval }\end{array}$ & 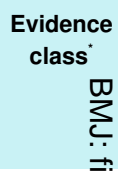 \\
\hline $\begin{array}{l}\text { Diabetes } \\
\text { incidence }^{42}\end{array}$ & $\begin{array}{l}\text { Patients with } \\
\text { hypertension }\end{array}$ & $\begin{array}{l}\text { Prospective or } \\
\text { retrospective } \\
\text { cohort }\end{array}$ & $\begin{array}{l}\text { Hyper } v \\
\text { normal }\end{array}$ & 2 & 8247 & 564 & aHR & $\begin{array}{c}1.84 \\
(1.02 \text { to } \\
3.30)\end{array}$ & 0.04 & NA & NA & 0.42 & NA & 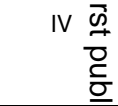 \\
\hline $\begin{array}{l}\text { Diabetic } \\
\text { nephropathy }{ }^{51}\end{array}$ & $\begin{array}{l}\text { Patients with } \\
\text { T2DM }\end{array}$ & Case-control & $\begin{array}{l}\text { Continuous } \\
\text { or categorical } \\
\text { SUA level }\end{array}$ & 3 & 3166 & 196 & OR & $\begin{array}{c}1.72 \\
(1.07 \text { to } \\
2.76)\end{array}$ & 0.03 & $\begin{array}{c}84 \\
(12 \\
\text { to } \\
93)\end{array}$ & 0.04 & NP & $\begin{array}{l}0.01 \text { to } \\
382.85\end{array}$ & 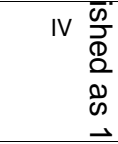 \\
\hline $\begin{array}{l}\text { Diabetic } \\
\text { microvascular } \\
\text { complications }^{51}\end{array}$ & $\begin{array}{l}\text { Patients with } \\
\text { T2DM }\end{array}$ & Case-control & $\begin{array}{l}\text { Continuous } \\
\text { or categorical } \\
\text { SUA level }\end{array}$ & 5 & 4513 & 854 & OR & $\begin{array}{c}1.42 \\
(1.11 \text { to } \\
1.83)\end{array}$ & 0.006 & $\begin{array}{c}83 \\
(61 \\
\text { to } \\
90) \\
\end{array}$ & 0.08 & NP & $\begin{array}{l}0.68 \text { to } \\
2.95\end{array}$ & 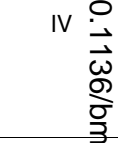 \\
\hline $\begin{array}{l}\text { Diabetic vascular } \\
\text { complications }^{52}\end{array}$ & $\begin{array}{l}\text { Patients with } \\
\text { T2DM }\end{array}$ & Case-control & $\begin{array}{l}\text { Continuous } \\
\text { or categorical } \\
\text { SUA level }\end{array}$ & 6 & 5017 & 967 & OR & $\begin{array}{c}1.27 \\
(1.11 \text { to } \\
1.45)\end{array}$ & 4.86E-04 & $\begin{array}{l}77 \\
(57 \\
\text { to } \\
86)\end{array}$ & 0.02 & 0.51 & $\begin{array}{c}0.87 \text { to } \\
1.86\end{array}$ & IV \\
\hline $\begin{array}{l}\text { Diabetic } \\
\text { peripheral } \\
\text { neuropathy }^{53}\end{array}$ & $\begin{array}{l}\text { Patients with } \\
\text { diabetes }\end{array}$ & $\begin{array}{l}\text { Cohort or } \\
\text { case-control }\end{array}$ & $\begin{array}{l}\text { Hyper } v \\
\text { normal }\end{array}$ & 5 & 4097 & 894 & $\mathrm{RR}$ & $\begin{array}{c}2.83 \\
(2.13 \text { to } \\
3.76)\end{array}$ & $2.91 \mathrm{E}-12$ & $\begin{array}{l}78 \\
(23 \\
\text { to } \\
89)\end{array}$ & 0.94 & 0.93 & $\begin{array}{l}1.05 \text { to } \\
7.62\end{array}$ & IV V \\
\hline $\begin{array}{l}\text { Diabetic } \\
\text { macrovascular } \\
\text { complications }^{51}\end{array}$ & $\begin{array}{l}\text { Patients with } \\
\text { T2DM }\end{array}$ & Case-control & $\begin{array}{l}\text { Continuous } \\
\text { or categorical } \\
\text { SUA level }\end{array}$ & 3 & 2538 & 187 & OR & $\begin{array}{c}1.03 \\
(1.00 \text { to } \\
1.06)\end{array}$ & 0.05 & $\begin{array}{c}48(0 \\
\text { to } \\
79) \\
\end{array}$ & 0.45 & 0.01 & $\begin{array}{l}0.56 \text { to } \\
2.30\end{array}$ & IV \\
\hline $\begin{array}{l}\text { Diabetic } \\
\text { retinopathy }^{51}\end{array}$ & $\begin{array}{l}\text { Patients with } \\
\text { T2DM }\end{array}$ & Case-control & $\begin{array}{l}\text { Continuous } \\
\text { or categorical } \\
\text { SUA level }\end{array}$ & 2 & 1739 & 311 & OR & $\begin{array}{c}1.23 \\
(0.81 \text { to } \\
1.87) \\
\end{array}$ & 0.34 & NA & NA & NP & NA & NS \\
\hline \multicolumn{15}{|l|}{ Kidney disorders } \\
\hline CKD incidence ${ }^{54}$ & $\begin{array}{l}\text { Middle aged } \\
\text { populations }\end{array}$ & $\begin{array}{l}\text { Prospective or } \\
\text { retrospective } \\
\text { cohort }\end{array}$ & $\begin{array}{l}1 \mathrm{mg} / \mathrm{dL} \text { SUA } \\
\text { increase }\end{array}$ & 15 & 99205 & 3492 & $\mathrm{RR}$ & $\begin{array}{c}1.22 \\
(1.16 \text { to } \\
1.28)\end{array}$ & $1.61 \mathrm{E}-14$ & $\begin{array}{c}66 \\
\text { (39 } \\
\text { to } \\
78) \\
\end{array}$ & 0.22 & 0.12 & $\begin{array}{c}1.02 \text { to } \\
1.44\end{array}$ & 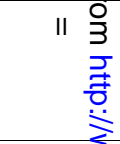 \\
\hline $\begin{array}{l}\text { CKD new onset } \\
\text { incidence }^{55}\end{array}$ & $\begin{array}{l}\text { Non-CKD } \\
\text { population }\end{array}$ & $\begin{array}{l}\text { Prospective or } \\
\text { retrospective } \\
\text { cohort }\end{array}$ & $\begin{array}{l}1 \mathrm{mg} / \mathrm{dL} \text { SUA } \\
\text { increase }\end{array}$ & 7 & 153620 & 7014 & $\mathrm{HR}$ & $\begin{array}{c}1.13 \\
(1.04 \text { to } \\
1.22)\end{array}$ & $2.74 \mathrm{E}-03$ & $\begin{array}{l}83 \\
(63 \\
\text { to } \\
90)\end{array}$ & 0.12 & 0.24 & $\begin{array}{l}0.88 \text { to } \\
1.44\end{array}$ & IV \\
\hline $\begin{array}{l}\text { CKD new onset } \\
{\text { incidence }{ }^{55}}^{55}\end{array}$ & $\begin{array}{l}\text { Patients with } \\
\text { diabetes }\end{array}$ & $\begin{array}{l}\text { Prospective or } \\
\text { retrospective } \\
\text { cohort }\end{array}$ & $\begin{array}{l}\text { Hyper } v \\
\text { normal }\end{array}$ & 2 & NA & NA & $\mathrm{HR}$ & $\begin{array}{c}1.90 \\
(1.30 \text { to } \\
2.78)\end{array}$ & $9.76 \mathrm{E}-04$ & NA & NA & 0.94 & NA & IV $\underset{\frac{0}{3}}{\frac{0}{3}}$ \\
\hline $\begin{array}{l}\text { Estimated } \\
\text { glomerular } \\
\text { filtration rate } \\
\end{array}$ & $\begin{array}{l}\text { Renal } \\
\text { transplant } \\
\text { recipients }\end{array}$ & $\begin{array}{l}\text { Prospective or } \\
\text { retrospective } \\
\text { cohort }\end{array}$ & $\begin{array}{l}\text { Hyper } v \\
\text { normal }\end{array}$ & 8 & 2075 & NA & $\begin{array}{c}\text { MD to } \\
\text { OR }\end{array}$ & $\begin{array}{c}0.36 \\
(0.26 \text { to } \\
0.52)\end{array}$ & $1.48 \mathrm{E}-08$ & $\begin{array}{c}66(3 \\
\text { to } \\
82) \\
\end{array}$ & 0.35 & 0.81 & $\begin{array}{c}0.13 \text { to } \\
1.06\end{array}$ & $\begin{array}{l}\text { IV } \\
\text { O } \\
\text { D } \\
\text { ․ }\end{array}$ \\
\hline Serum creatinine ${ }^{56}$ & $\begin{array}{l}\text { Renal } \\
\text { transplant } \\
\text { recipients }\end{array}$ & $\begin{array}{l}\text { Prospective or } \\
\text { retrospective } \\
\text { cohort }\end{array}$ & $\begin{array}{l}\text { Hyper } v \\
\text { normal }\end{array}$ & 5 & 873 & NA & $\begin{array}{l}\text { MD to } \\
\text { OR }\end{array}$ & $\begin{array}{c}2.45 \\
(1.69 \text { to } \\
3.54)\end{array}$ & 2.77E-06 & $\begin{array}{l}40(0 \\
\text { to } \\
77) \\
\end{array}$ & 0.15 & 0.65 & $\begin{array}{c}0.88 \text { to } \\
6.81\end{array}$ & $\begin{array}{l}\text { IV N } \\
\text { N } \\
\text { ర } \\
\end{array}$ \\
\hline Graft loss ${ }^{56}$ & $\begin{array}{l}\text { Renal } \\
\text { transplant } \\
\text { recipients }\end{array}$ & $\begin{array}{l}\text { Prospective or } \\
\text { retrospective } \\
\text { cohort }\end{array}$ & $\begin{array}{l}\text { Hyper } v \\
\text { normal }\end{array}$ & 3 & 910 & 154 & OR & $\begin{array}{c}2.28 \\
(1.54 \text { to } \\
3.38)\end{array}$ & 4.66E-05 & $\begin{array}{l}0(0 \\
\text { to } \\
73)\end{array}$ & 0.57 & NP & $\begin{array}{l}0.18 \text { to } \\
29.36\end{array}$ & IV $\underset{\substack{c \\
\mathbb{D}}}{\stackrel{\mathscr{C}}{+}}$ \\
\hline $\begin{array}{l}\text { Chronic allograft } \\
\text { nephropathy }^{56}\end{array}$ & $\begin{array}{l}\text { Renal } \\
\text { transplant } \\
\text { recipients }\end{array}$ & $\begin{array}{l}\text { Prospective or } \\
\text { retrospective } \\
\text { cohort }\end{array}$ & $\begin{array}{l}\text { Hyper } v \\
\text { normal }\end{array}$ & 4 & 1057 & 113 & OR & $\begin{array}{c}2.81 \\
(1.65 \text { to } \\
4.77)\end{array}$ & $1.52 \mathrm{E}-04$ & $\begin{array}{c}26(0 \\
\text { to } \\
75) \\
\end{array}$ & 0.92 & NP & $\begin{array}{c}0.53 \text { to } \\
14.76\end{array}$ & 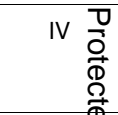 \\
\hline \multicolumn{15}{|c|}{ Neurocognitive disorders } \\
\hline $\begin{array}{l}\text { Alzheimer's } \\
\text { disease }^{57}\end{array}$ & General & $\begin{array}{l}\text { Cohort or } \\
\text { case-control }\end{array}$ & $\begin{array}{l}\text { SUA level } \\
(\mathrm{mg} / \mathrm{dL})\end{array}$ & 21 & 3617 & 1128 & $\begin{array}{l}\text { MD to } \\
\text { OR }\end{array}$ & $\begin{array}{c}0.29 \\
(0.11 \text { to } \\
0.76)\end{array}$ & 0.012 & $\begin{array}{l}97 \\
(96 \\
\text { to } \\
97)\end{array}$ & 0.30 & NP & $\begin{array}{l}0.01 \text { to } \\
8.97\end{array}$ & 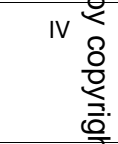 \\
\hline $\begin{array}{l}\text { Dementia or } \\
\text { cognitive } \\
\text { impairment }^{58}\end{array}$ & General & $\begin{array}{l}\text { Cohort or } \\
\text { case-control }\end{array}$ & $\begin{array}{l}\text { SUA level } \\
(\mathrm{mg} / \mathrm{dL})\end{array}$ & 31 & 7021 & 2681 & $\begin{array}{c}\text { SMD to } \\
\text { OR }\end{array}$ & $\begin{array}{c}0.58 \\
(0.41 \text { to } \\
0.83)\end{array}$ & 0.003 & $\begin{array}{l}89 \\
(86 \\
\text { to } \\
91)\end{array}$ & 0.01 & 0.004 & $\begin{array}{c}0.08 \text { to } \\
4.48\end{array}$ & $\mathrm{IV} \stackrel{+}{\stackrel{+}{+}}$ \\
\hline
\end{tabular}


Table 1 (continued)

\begin{tabular}{|c|c|c|c|c|c|c|c|c|c|c|c|c|c|c|}
\hline Outcomes & Population & $\begin{array}{c}\text { Study design } \\
\text { included in } \\
\text { MA }\end{array}$ & Comparison & $\begin{array}{l}\text { No of } \\
\text { studies }\end{array}$ & $\begin{array}{c}\text { No of } \\
\text { participants }\end{array}$ & $\begin{array}{l}\text { No of } \\
\text { cases }\end{array}$ & $\begin{array}{c}\text { Type of } \\
\text { metric }\end{array}$ & $\begin{array}{l}\text { Relative } \\
\text { risk } \\
(95 \% \mathrm{Cl})\end{array}$ & $P$ value & $\begin{array}{c}I^{2} \\
(95 \% \\
\mathrm{Cl})\end{array}$ & $\begin{array}{c}P \\
\text { value } \\
\text { for } \\
\text { Egger } \\
\text { test }\end{array}$ & $\begin{array}{l}P \text { value for } \\
\text { excess } \\
\text { significance } \\
\text { test }\end{array}$ & $\begin{array}{c}95 \% \\
\text { prediction } \\
\text { interval }\end{array}$ & 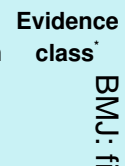 \\
\hline $\operatorname{VaD}^{58}$ & $\begin{array}{l}\text { Patients with } \\
\text { VaD } v \\
\text { controls }\end{array}$ & $\begin{array}{l}\text { Cohort or } \\
\text { case-control }\end{array}$ & $\begin{array}{l}\text { SUA level } \\
\text { (mg/LI) }\end{array}$ & 7 & 597 & 272 & $\begin{array}{l}\text { SMD to } \\
\text { OR }\end{array}$ & $\begin{array}{c}0.92 \\
(0.20 \text { to } \\
4.12)\end{array}$ & 0.92 & $\begin{array}{c}94 \\
(90 \\
\text { to } \\
96)\end{array}$ & 0.45 & $<0.001$ & $\begin{array}{l}0.01 \text { to } \\
200.17\end{array}$ & 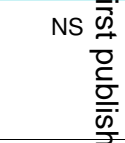 \\
\hline $\mathrm{MCl}^{58}$ & $\begin{array}{l}\text { Patients with } \\
\text { MCl } v \text { controls }\end{array}$ & $\begin{array}{l}\text { Cohort or } \\
\text { case-control }\end{array}$ & $\begin{array}{l}\text { SUA level } \\
\text { (mg/dL) }\end{array}$ & 4 & 731 & 515 & $\begin{array}{c}\text { SMD to } \\
\text { OR }\end{array}$ & $\begin{array}{c}0.65 \\
(0.20 \text { to } \\
2.17)\end{array}$ & 0.49 & $\begin{array}{l}92 \\
(83 \\
\text { to } \\
95)\end{array}$ & 0.36 & 0.52 & $\begin{array}{l}0.01 \text { to } \\
63.36\end{array}$ & 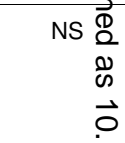 \\
\hline $\begin{array}{l}\text { Parkinson's } \\
\text { disease } \\
\text { incidence }^{59}\end{array}$ & General & $\begin{array}{l}\text { Cohort and } \\
\text { nested } \\
\text { case-control }\end{array}$ & $\begin{array}{l}\text { Hyper } v \\
\text { normal }\end{array}$ & 6 & 33185 & 578 & RR & $\begin{array}{c}0.65 \\
(0.43 \text { to } \\
0.97)\end{array}$ & 0.04 & $\begin{array}{l}42(0 \\
\text { to } \\
73)\end{array}$ & 0.39 & NP & $\begin{array}{c}0.24 \text { to } \\
1.77\end{array}$ & IV $\overrightarrow{\vec{\omega}}$ \\
\hline $\mathrm{MS}^{60}$ & $\begin{array}{l}\text { Patients with } \\
\text { MS } v \text { control }\end{array}$ & Case-control & $\begin{array}{l}\text { SUA level } \\
(\mu \mathrm{mol} / \mathrm{L})\end{array}$ & 10 & 2216 & 1308 & $\begin{array}{l}\text { SMD to } \\
\text { OR }\end{array}$ & $\begin{array}{c}0.49 \\
(0.27 \text { to } \\
0.87)\end{array}$ & 0.02 & $\begin{array}{l}92 \\
(88 \\
\text { to } \\
94)\end{array}$ & 0.11 & $\mathrm{NP}$ & $\begin{array}{c}0.05 \text { to } \\
4.96\end{array}$ & 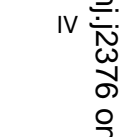 \\
\hline $\mathrm{NMO}^{60}$ & $\begin{array}{l}\text { Patients with } \\
\text { NMO } v \text { control }\end{array}$ & Case-control & $\begin{array}{l}\text { SUA level } \\
(\mu \mathrm{mol} / \mathrm{L})\end{array}$ & 3 & 1137 & 229 & $\begin{array}{l}\text { SMD to } \\
\text { OR }\end{array}$ & $\begin{array}{c}0.22 \\
(0.10 \text { to } \\
0.45)\end{array}$ & $9.07 \mathrm{E}-05$ & $\begin{array}{c}82 \\
(49 \\
\text { to } \\
91)\end{array}$ & 0.65 & 0.93 & $\begin{array}{c}0.02 \text { to } \\
3.14\end{array}$ & 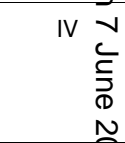 \\
\hline ALS $^{61}$ & $\begin{array}{l}\text { Patients with } \\
\text { ALS } v \text { controls }\end{array}$ & Case-control & $\begin{array}{l}\text { SUA level } \\
(\mathrm{mg} / \mathrm{dL})\end{array}$ & 3 & 826 & 311 & $\begin{array}{l}\text { Hedge's } \\
\text { G to OR }\end{array}$ & $\begin{array}{c}0.21 \\
(0.14 \text { to } \\
0.32)\end{array}$ & $6.33 \mathrm{E}-13$ & $\begin{array}{l}51(0 \\
\text { to } \\
82)\end{array}$ & 0.43 & NP & $\begin{array}{l}0.04 \text { to } \\
1.05\end{array}$ & IV \\
\hline $\begin{array}{l}\text { Schizophrenia } \\
\text { (chronic) } \dagger^{62}\end{array}$ & $\begin{array}{l}\text { Patients with } \\
\text { chronic } \\
\text { schizophrenia } \\
v \text { controls }\end{array}$ & Case-control & $\begin{array}{l}\text { SUA level } \\
\text { (mg/dL) }\end{array}$ & 2 & 274 & 155 & $\begin{array}{l}\text { Hedge's } \\
\text { G to OR }\end{array}$ & $\begin{array}{c}0.72 \\
(0.43 \text { to } \\
1.21)\end{array}$ & 0.22 & NA & NA & NP & NA & 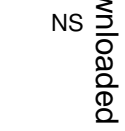 \\
\hline $\begin{array}{l}\text { Schizophrenia } \\
\text { (first episode } \\
\text { psychosis) }\end{array}$ & $\begin{array}{l}\text { Patients with } \\
\text { schizophrenia } \\
\text { in first episode } \\
\text { psychosis } v \\
\text { controls }\end{array}$ & Case-control & $\begin{array}{l}\text { SUA level } \\
(\mathrm{mg} / \mathrm{dL})\end{array}$ & 3 & 277 & 103 & $\begin{array}{l}\text { Hedge's } \\
\text { G to OR }\end{array}$ & $\begin{array}{c}0.37 \\
(0.23 \text { to } \\
0.59)\end{array}$ & $4.16 \mathrm{E}-05$ & $\begin{array}{l}0(0 \\
\text { to } \\
73)\end{array}$ & 0.50 & 0.21 & $\begin{array}{l}0.02 \text { to } \\
7.75\end{array}$ & 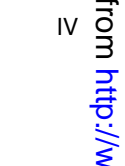 \\
\hline Bipolar disorder ${ }^{63}$ & $\begin{array}{l}\text { Patients with } \\
\text { bipolar } \\
\text { disorder } v \\
\text { controls }\end{array}$ & Case-control & $\begin{array}{l}\text { SUA level } \\
(\mathrm{mg} / \mathrm{dL})\end{array}$ & 9 & 1127 & 619 & $\begin{array}{l}\text { SMD to } \\
\text { OR }\end{array}$ & $\begin{array}{c}3.23 \\
(1.82 \text { to } \\
5.73)\end{array}$ & $7.09 \mathrm{E}-05$ & $\begin{array}{c}83 \\
(66 \\
\text { to } \\
89) \\
\end{array}$ & 0.19 & $\mathrm{NP}$ & $\begin{array}{c}0.65 \text { to } \\
12.39\end{array}$ & IV \\
\hline \multicolumn{15}{|l|}{ Cancer outcomes } \\
\hline $\begin{array}{l}\text { Cancer } \\
\text { incidence }^{64}\end{array}$ & General & $\begin{array}{l}\text { Prospective } \\
\text { cohort }\end{array}$ & $\begin{array}{l}\text { Highest } v \\
\text { lowest SUA } \\
\text { category }\end{array}$ & 5 & 456053 & $\begin{array}{c}14 \\
355\end{array}$ & RR & $\begin{array}{c}1.04 \\
(0.99 \text { to } \\
1.08)\end{array}$ & 0.08 & $\begin{array}{l}45(0 \\
\text { to } \\
78)\end{array}$ & 0.30 & 0.16 & $\begin{array}{c}0.93 \text { to } \\
1.14\end{array}$ & NS 옥 \\
\hline $\begin{array}{l}\text { Cancer incidence } \\
\text { in digestive } \\
\text { organs }^{64}\end{array}$ & General & $\begin{array}{l}\text { Prospective } \\
\text { cohort }\end{array}$ & $\begin{array}{l}\text { Highest } v \\
\text { lowest SUA } \\
\text { category }\end{array}$ & 3 & 266347 & 2521 & RR & $\begin{array}{l}1.06 \\
(0.96 \text { to } \\
1.18)\end{array}$ & 0.27 & $\begin{array}{l}53(0 \\
\text { to } \\
79)\end{array}$ & 0.58 & 0.65 & $\begin{array}{c}0.81 \text { to } \\
1.40\end{array}$ & 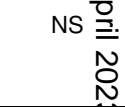 \\
\hline 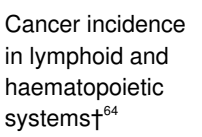 & General & $\begin{array}{l}\text { Prospective } \\
\text { cohort }\end{array}$ & $\begin{array}{l}\text { Highest } v \\
\text { lowest SUA } \\
\text { category }\end{array}$ & 2 & 86739 & 397 & RR & $\begin{array}{c}1.39 \\
(1.13 \text { to } \\
1.71)\end{array}$ & 0.002 & NA & NA & NP & NA & 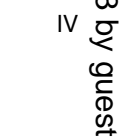 \\
\hline $\begin{array}{l}\text { Cancer incidence } \\
\text { in male genital } \\
\text { organs }^{64}\end{array}$ & General & $\begin{array}{l}\text { Prospective } \\
\text { cohort }\end{array}$ & $\begin{array}{l}\text { Highest } v \\
\text { lowest SUA } \\
\text { category }\end{array}$ & 3 & 162022 & 2634 & $\mathrm{RR}$ & $\begin{array}{l}1.08 \\
(0.96 \text { to } \\
1.21)\end{array}$ & 0.19 & $\begin{array}{l}61(0 \\
\text { to } \\
87)\end{array}$ & 0.45 & 0.63 & $\begin{array}{c}0.28 \text { to } \\
4.18\end{array}$ & NS $\frac{0}{0}$ \\
\hline $\begin{array}{l}\text { Cancer incidence } \\
\text { in respiratory } \\
\text { system and } \\
\text { intrathoracic } \\
\text { organs }^{64}\end{array}$ & General & $\begin{array}{l}\text { Prospective } \\
\text { cohort }\end{array}$ & $\begin{array}{l}\text { Highest } v \\
\text { lowest SUA } \\
\text { category }\end{array}$ & 4 & 456053 & 2941 & RR & $\begin{array}{c}1.05 \\
(0.93 \text { to } \\
1.18)\end{array}$ & 0.43 & $\begin{array}{l}71(0 \\
\text { to } \\
87)\end{array}$ & 0.62 & 0.49 & $\begin{array}{c}0.72 \text { to } \\
1.54\end{array}$ & 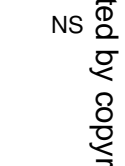 \\
\hline $\begin{array}{l}\text { Cancer incidence } \\
\text { in urinary } \\
\text { organs }^{64}\end{array}$ & General & $\begin{array}{l}\text { Prospective } \\
\text { cohort }\end{array}$ & $\begin{array}{l}\text { Highest } v \\
\text { lowest SUA } \\
\text { category }\end{array}$ & 2 & 86739 & 536 & RR & $\begin{array}{l}1.17 \\
(0.44 \text { to } \\
3.15)\end{array}$ & 0.77 & NA & NA & 0.02 & NA & NS $\stackrel{\bar{\alpha}}{\bar{P}}$ \\
\hline
\end{tabular}

\section{All cause and cause specific mortality}


Table 1 (continued)

\begin{tabular}{|c|c|c|c|c|c|c|c|c|c|c|c|c|c|c|}
\hline Outcomes & Population & $\begin{array}{c}\text { Study design } \\
\text { included in } \\
\text { MA }\end{array}$ & Comparison & $\begin{array}{c}\text { No of } \\
\text { studies }\end{array}$ & $\begin{array}{c}\text { No of } \\
\text { participants }\end{array}$ & $\begin{array}{l}\text { No of } \\
\text { cases }\end{array}$ & $\begin{array}{l}\text { Type of } \\
\text { metric }\end{array}$ & $\begin{array}{c}\text { Relative } \\
\text { risk } \\
(95 \% \mathrm{Cl})\end{array}$ & $P$ value & $\begin{array}{c}I^{2} \\
(95 \% \\
\text { Cl) }\end{array}$ & $\begin{array}{l}P \\
\text { value } \\
\text { for } \\
\text { Egger } \\
\text { test }\end{array}$ & $\begin{array}{l}P \text { value for } \\
\text { excess } \\
\text { significance } \\
\text { test }\end{array}$ & $\begin{array}{c}95 \% \\
\text { prediction } \\
\text { interval }\end{array}$ & 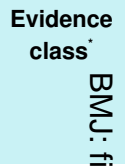 \\
\hline $\begin{array}{l}\text { Coronary heart } \\
\text { disease } \\
\text { mortality }^{\star 41}\end{array}$ & General & $\begin{array}{l}\text { Prospective } \\
\text { cohort }\end{array}$ & $\begin{array}{l}\text { Hyper } v \\
\text { normal }\end{array}$ & 13 & 876584 & $\begin{array}{c}24 \\
198\end{array}$ & $\mathrm{aRR}$ & $\begin{array}{c}1.27 \\
(1.16 \text { to } \\
1.39)\end{array}$ & $3.46 \mathrm{E}-07$ & $\begin{array}{l}65 \\
(36 \\
\text { to } \\
78) \\
\end{array}$ & 0.10 & NP & $\begin{array}{c}0.96 \text { to } \\
1.69\end{array}$ & ॥ $\frac{\overline{0}}{\frac{0}{0}}$ \\
\hline CVD mortality ${ }^{65}$ & General & $\begin{array}{l}\text { Prospective } \\
\text { cohort }\end{array}$ & $\begin{array}{l}\text { Highest } v \\
\text { lowest SUA } \\
\text { category }\end{array}$ & 9 & 165806 & 6121 & $\mathrm{RR}$ & $\begin{array}{c}1.37 \\
(1.19 \text { to } \\
1.57)\end{array}$ & 1.07E-05 & $\begin{array}{c}54(0 \\
\text { to } \\
74)\end{array}$ & 0.59 & NP & $\begin{array}{l}0.92 \text { to } \\
2.03\end{array}$ & III 㐫 \\
\hline CVD mortality ${ }^{43}$ & $\begin{array}{l}\text { Patients with } \\
\text { heart failure }\end{array}$ & $\begin{array}{l}\text { Prospective } \\
\text { cohort }\end{array}$ & $\begin{array}{l}\text { Hyper } v \\
\text { normal }\end{array}$ & 2 & 2250 & NA & $\mathrm{HR}$ & $\begin{array}{c}1.45 \\
(1.18 \text { to } \\
1.78)\end{array}$ & $4.25 E-04$ & NA & NA & NP & NA & 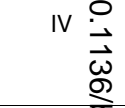 \\
\hline CVD mortality ${ }^{42}$ & $\begin{array}{l}\text { Patients with } \\
\text { hypertension }\end{array}$ & $\begin{array}{l}\text { Prospective or } \\
\text { retrospective } \\
\text { cohort }\end{array}$ & $\begin{array}{l}\text { Hyper } v \\
\text { normal }\end{array}$ & 3 & NA & NA & aHR & $\begin{array}{c}1.31 \\
(0.96 \text { to } \\
1.78)\end{array}$ & 0.09 & NA & NA & NA & NA & 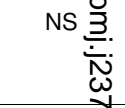 \\
\hline Stroke mortality ${ }^{48}$ & General & $\begin{array}{l}\text { Prospective } \\
\text { cohort }\end{array}$ & $\begin{array}{l}\text { Highest } v \\
\text { lowest SUA } \\
\text { category }\end{array}$ & 9 & 1017810 & $\begin{array}{c}21 \\
281\end{array}$ & aRR & $\begin{array}{c}1.32 \\
(1.23 \text { to } \\
1.41) \\
\end{array}$ & $1.11 \mathrm{E}-14$ & $\begin{array}{c}30(0 \\
\text { to } \\
65)\end{array}$ & 0.92 & NP & $\begin{array}{c}1.13 \text { to } \\
1.56\end{array}$ & $\begin{array}{l}\text { ‡ } \\
\text { 음 } \\
\text { v }\end{array}$ \\
\hline CKD mortality $^{66}$ & General & $\begin{array}{l}\text { Prospective } \\
\text { cohort }\end{array}$ & $\begin{array}{l}1 \mathrm{mg} / \mathrm{dL} \text { SUA } \\
\text { increase }\end{array}$ & 21 & 23443 & 3904 & aHR & $\begin{array}{c}1.07 \\
(1.04 \text { to } \\
1.11)\end{array}$ & 5.46E-05 & $\begin{array}{l}82 \\
(74 \\
\text { to } \\
87) \\
\end{array}$ & 0.04 & 0.03 & $\begin{array}{c}0.93 \text { to } \\
1.24\end{array}$ & 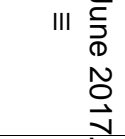 \\
\hline Cancer mortality ${ }^{64}$ & General & $\begin{array}{l}\text { Prospective } \\
\text { cohort }\end{array}$ & $\begin{array}{l}\text { Highest } v \\
\text { lowest SUA } \\
\text { category }\end{array}$ & 12 & 632472 & NA & $\mathrm{RR}$ & $\begin{array}{c}1.17 \\
\text { (1.04 to } \\
1.32)\end{array}$ & 0.01 & $\begin{array}{l}66 \\
(25 \\
\text { to } \\
80)\end{array}$ & 0.36 & NP & $\begin{array}{c}0.82 \text { to } \\
1.69\end{array}$ & IV ฮ \\
\hline $\begin{array}{l}\text { Cancer mortality } \\
\text { in digestive } \\
\text { organs }^{64}\end{array}$ & General & $\begin{array}{l}\text { Prospective } \\
\text { cohort }\end{array}$ & $\begin{array}{l}\text { Highest } v \\
\text { lowest SUA } \\
\text { category }\end{array}$ & 4 & 187886 & 855 & $\mathrm{RR}$ & $\begin{array}{c}1.22 \\
(0.86 \text { to } \\
1.74)\end{array}$ & 0.27 & $\begin{array}{c}55(0 \\
\text { to } \\
80)\end{array}$ & 0.99 & NP & $\begin{array}{c}0.45 \text { to } \\
3.31\end{array}$ & 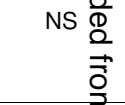 \\
\hline $\begin{array}{l}\text { Cancer mortality } \\
\text { in bone, } \\
\text { connective tissue, } \\
\text { soft tissue, and } \\
\text { skin }^{64}\end{array}$ & General & $\begin{array}{l}\text { Prospective } \\
\text { cohort }\end{array}$ & $\begin{array}{l}\text { Highest } v \\
\text { lowest SUA } \\
\text { category }\end{array}$ & NA & 112296 & NA & $\mathrm{RR}$ & $\begin{array}{c}0.94 \\
(0.47 \text { to } \\
1.87)\end{array}$ & 0.87 & NA & NA & NA & NA & 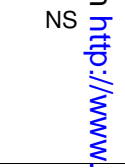 \\
\hline $\begin{array}{l}\text { Cancer mortality } \\
\text { in lymphoid and } \\
\text { haematopoietic } \\
{\text { systems }{ }^{64}}^{64}\end{array}$ & General & $\begin{array}{l}\text { Prospective } \\
\text { cohort }\end{array}$ & $\begin{array}{l}\text { Highest } v \\
\text { lowest SUA } \\
\text { category }\end{array}$ & NA & 112296 & NA & $\mathrm{RR}$ & $\begin{array}{c}1.18 \\
(0.82 \text { to } \\
1.70)\end{array}$ & 0.38 & NA & NA & NA & NA & NS $\frac{0}{3}$. \\
\hline $\begin{array}{l}\text { Cancer mortality } \\
\text { in male genital } \\
{\text { organs } \dagger^{64}}\end{array}$ & General & $\begin{array}{l}\text { Prospective } \\
\text { cohort }\end{array}$ & $\begin{array}{l}\text { Highest } v \\
\text { lowest SUA } \\
\text { category }\end{array}$ & NA & 88033 & NA & $\mathrm{RR}$ & $\begin{array}{c}0.51 \\
(0.07 \text { to } \\
3.85)\end{array}$ & 0.52 & NA & NA & NA & NA & $\begin{aligned} & \text { NS } \text { 음 } \\
& N \\
& \text { O } \\
& \text { D }\end{aligned}$ \\
\hline $\begin{array}{l}\text { Cancer mortality } \\
\text { in respiratory } \\
\text { system and } \\
\text { intrathoracic } \\
{\text { organs } \dagger^{64}} \\
\end{array}$ & General & $\begin{array}{l}\text { Prospective } \\
\text { cohort }\end{array}$ & $\begin{array}{l}\text { Highest } v \\
\text { lowest SUA } \\
\text { category }\end{array}$ & 2 & 116646 & 164 & $\mathrm{RR}$ & $\begin{array}{c}1.08 \\
(0.61 \text { to } \\
1.91)\end{array}$ & 0.80 & NA & NA & NP & NA & $\begin{array}{l}\text { NS 号. } \\
\text { N } \\
\text { N } \\
\text { O } \\
\text { থ }\end{array}$ \\
\hline $\begin{array}{l}\text { Cancer mortality } \\
\text { in urinary } \\
{\text { organs } \dagger^{64}}\end{array}$ & General & $\begin{array}{l}\text { Prospective } \\
\text { cohort }\end{array}$ & $\begin{array}{l}\text { Highest } v \\
\text { lowest SUA } \\
\text { category }\end{array}$ & 2 & 112296 & NA & $\mathrm{RR}$ & $\begin{array}{c}1.35 \\
(0.88 \text { to } \\
2.07)\end{array}$ & 0.17 & NA & NA & NP & NA & 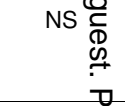 \\
\hline $\begin{array}{l}\text { All cause } \\
\text { mortality }{ }^{43}\end{array}$ & $\begin{array}{l}\text { Patients with } \\
\text { heart failure }\end{array}$ & $\begin{array}{l}\text { Cohort or } \\
\text { case-control }\end{array}$ & $\begin{array}{l}\text { Hyper } v \\
\text { normal }\end{array}$ & 11 & 12444 & 1888 & $\mathrm{HR}$ & $\begin{array}{c}2.15 \\
(1.64 \text { to } \\
2.83)\end{array}$ & 6.64E-08 & $\begin{array}{l}81 \\
(67 \\
\text { to } \\
88)\end{array}$ & 0.01 & 0.37 & $\begin{array}{c}0.87 \text { to } \\
5.31\end{array}$ & 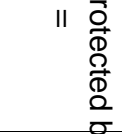 \\
\hline $\begin{array}{l}\text { Short term } \\
\text { mortality }{ }^{47}\end{array}$ & $\begin{array}{l}\text { Patients with } \\
\text { AMI }\end{array}$ & $\begin{array}{l}\text { Prospective or } \\
\text { retrospective } \\
\text { cohort }\end{array}$ & $\begin{array}{l}\text { Highest } v \\
\text { lowest SUA } \\
\text { category }\end{array}$ & 8 & 6805 & 396 & OR & $\begin{array}{c}3.24 \\
(2.47 \text { to } \\
4.27)\end{array}$ & $3.75 \mathrm{E}-16$ & $\begin{array}{c}31(0 \\
\text { to } \\
69)\end{array}$ & 0.83 & NP & $\begin{array}{l}1.74 \text { to } \\
6.06\end{array}$ & $\begin{array}{l}\text { IV } \\
\text { 음 } \\
\text { 므 }\end{array}$ \\
\hline $\begin{array}{l}\text { Medium term } \\
\text { mortality }^{47}\end{array}$ & $\begin{array}{l}\text { Patients with } \\
\text { AMI }\end{array}$ & $\begin{array}{l}\text { Prospective or } \\
\text { retrospective } \\
\text { cohort }\end{array}$ & $\begin{array}{l}\text { Highest } v \\
\text { lowest SUA } \\
\text { category }\end{array}$ & 5 & 5194 & 565 & OR & $\begin{array}{c}2.69 \\
(2.00 \text { to } \\
3.62)\end{array}$ & $1.75 \mathrm{E}-10$ & $\begin{array}{c}55(0 \\
\text { to } \\
81)\end{array}$ & 0.66 & NP & $\begin{array}{l}1.09 \text { to } \\
6.67\end{array}$ & IV $\underset{P}{\stackrel{\widehat{Q}}{P}}$ \\
\hline
\end{tabular}


Table 1 (continued)

\begin{tabular}{|c|c|c|c|c|c|c|c|c|c|c|c|c|c|c|}
\hline Outcomes & Population & $\begin{array}{c}\text { Study design } \\
\text { included in } \\
\text { MA }\end{array}$ & Comparison & $\begin{array}{c}\text { No of } \\
\text { studies }\end{array}$ & $\begin{array}{c}\text { No of } \\
\text { participants }\end{array}$ & $\begin{array}{l}\text { No of } \\
\text { cases }\end{array}$ & $\begin{array}{l}\text { Type of } \\
\text { metric }\end{array}$ & $\begin{array}{l}\text { Relative } \\
\text { risk } \\
(95 \% \mathrm{Cl})\end{array}$ & $P$ value & $\begin{array}{c}I^{2} \\
(95 \% \\
\text { Cl) }\end{array}$ & $\begin{array}{l}P \\
\text { value } \\
\text { for } \\
\text { Egger } \\
\text { test }\end{array}$ & $\begin{array}{l}P \text { value for } \\
\text { excess } \\
\text { significance } \\
\text { test }\end{array}$ & $\begin{array}{c}95 \% \\
\text { prediction } \\
\text { interval }\end{array}$ & 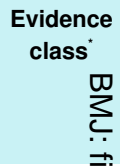 \\
\hline $\begin{array}{l}\text { In hospital } \\
\text { mortality }^{68}\end{array}$ & $\begin{array}{l}\text { Patients with } \\
\text { AMI }\end{array}$ & Cohort & $\begin{array}{l}\text { Hyper } v \\
\text { normal }\end{array}$ & 6 & 5686 & 218 & $\mathrm{RR}$ & $\begin{array}{c}2.10 \\
(1.03 \text { to } \\
4.26)\end{array}$ & 0.04 & $\begin{array}{l}81 \\
(51 \\
\text { to } \\
90)\end{array}$ & 0.86 & NP & $\begin{array}{l}0.21 \text { to } \\
20.66\end{array}$ & IV $\frac{\bar{\sigma}}{\frac{0}{\sigma}}$ \\
\hline $\begin{array}{l}\text { All cause } \\
\text { mortality }{ }^{51}\end{array}$ & $\begin{array}{l}\text { Patients with } \\
\text { T2DM }\end{array}$ & $\begin{array}{l}\text { Cohort or } \\
\text { case-control }\end{array}$ & $\begin{array}{l}\text { Hyper } v \\
\text { normal }\end{array}$ & 3 & 5534 & NA & $\mathrm{HR}$ & $\begin{array}{c}1.09 \\
(1.03 \text { to } \\
1.17)\end{array}$ & 0.008 & $\begin{array}{l}19(0 \\
\text { to } \\
73)\end{array}$ & 0.49 & NP & $\begin{array}{l}0.90 \text { to } \\
1.33\end{array}$ & IV 离 \\
\hline $\begin{array}{l}\text { All cause } \\
\text { mortality }\end{array}$ & General & $\begin{array}{l}\text { Prospective } \\
\text { cohort }\end{array}$ & $\begin{array}{l}\text { Highest } v \\
\text { lowest SUA } \\
\text { category }\end{array}$ & 10 & 143483 & 7031 & $\mathrm{RR}$ & $\begin{array}{c}1.23 \\
(1.08 \text { to } \\
1.39)\end{array}$ & 0.001 & $\begin{array}{l}75 \\
(56 \\
\text { to } \\
84)\end{array}$ & 0.51 & NP & $\begin{array}{c}0.79 \text { to } \\
1.90\end{array}$ & IV $\underset{\text { c. }}{\vec{\omega}}$ \\
\hline $\begin{array}{l}\text { All cause } \\
\text { mortality }\end{array}$ & $\begin{array}{l}\text { Patients after } \\
\mathrm{PCl}\end{array}$ & $\begin{array}{l}\text { Prospective or } \\
\text { retrospective } \\
\text { cohort }\end{array}$ & $\begin{array}{l}\text { Hyper } v \\
\text { normal }\end{array}$ & 9 & 17268 & NA & $\mathrm{RR}$ & $\begin{array}{c}1.52 \\
(1.28 \text { to } \\
1.81)\end{array}$ & $2.95 \mathrm{E}-06$ & $\begin{array}{c}64(3 \\
\text { to } \\
81)\end{array}$ & 0.002 & NP & $\begin{array}{l}0.98 \text { to } \\
2.24\end{array}$ & 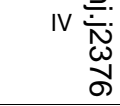 \\
\hline $\begin{array}{l}\text { All cause } \\
\text { mortality }\end{array}$ & $\begin{array}{l}\text { Hypertensive } \\
\text { patients }\end{array}$ & $\begin{array}{l}\text { Prospective or } \\
\text { retrospective } \\
\text { cohort }\end{array}$ & $\begin{array}{l}\text { Hyper } v \\
\text { normal }\end{array}$ & 4 & 46103 & 5820 & aHR & $\begin{array}{c}1.12 \\
(1.02 \text { to } \\
1.23)\end{array}$ & 0.02 & $\begin{array}{c}26(0 \\
\text { to } \\
76)\end{array}$ & 0.77 & 0.93 & $\begin{array}{c}0.86 \text { to } \\
1.49\end{array}$ & 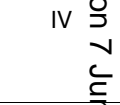 \\
\hline $\begin{array}{l}\text { All cause } \\
\text { mortality }{ }^{42}\end{array}$ & $\begin{array}{l}\text { Patients with } \\
\text { CKD }\end{array}$ & $\begin{array}{l}\text { Prospective or } \\
\text { retrospective } \\
\text { cohort }\end{array}$ & $\begin{array}{l}\text { Hyper } v \\
\text { normal }\end{array}$ & 5 & 1789 & 609 & $\mathrm{RR}$ & $\begin{array}{c}1.67 \\
(1.29 \text { to } \\
2.16)\end{array}$ & $1.09 \mathrm{E}-04$ & NA & NA & NA & NA & $\begin{array}{l}\text { IV } \\
\text { No } \\
\text { O }\end{array}$ \\
\hline \multicolumn{15}{|l|}{ Other outcomes } \\
\hline $\begin{array}{l}\text { Medium or long } \\
\text { term occurrence } \\
\text { of death or } \\
\text { MACE }^{47}\end{array}$ & $\begin{array}{l}\text { Patients with } \\
\text { AMI }\end{array}$ & $\begin{array}{l}\text { Prospective or } \\
\text { retrospective } \\
\text { cohort }\end{array}$ & $\begin{array}{l}50 \mu \mathrm{mol} / \mathrm{L} \\
\text { increase }\end{array}$ & 4 & 3533 & NA & aHR & $\begin{array}{c}1.19 \\
(1.03 \text { to } \\
1.37)\end{array}$ & 0.02 & $\begin{array}{l}84 \\
(47 \\
\text { to } \\
92)\end{array}$ & 0.03 & NP & $\begin{array}{l}0.65 \text { to } \\
2.18\end{array}$ & IV \\
\hline $\begin{array}{l}\text { Short term } \\
\text { occurrence of } \\
\text { death or MACE }{ }^{47}\end{array}$ & $\begin{array}{l}\text { Patients with } \\
\text { AMI }\end{array}$ & $\begin{array}{l}\text { Prospective or } \\
\text { retrospective } \\
\text { cohort }\end{array}$ & $\begin{array}{l}\text { Highest } v \\
\text { lowest SUA } \\
\text { category }\end{array}$ & 4 & 3625 & 336 & $\mathrm{aOR}$ & $\begin{array}{c}2.26 \\
(1.85 \text { to } \\
2.77)\end{array}$ & $1.61 \mathrm{E}-14$ & $\begin{array}{l}0(0 \\
\text { to } \\
68)\end{array}$ & 0.97 & 0.23 & $\begin{array}{c}1.45 \text { to } \\
3.53\end{array}$ & IV $\begin{array}{l}\underset{\overline{0}}{3} \\
\frac{2}{2}\end{array}$ \\
\hline $\begin{array}{l}\text { Combined death } \\
\text { or cardiac events }\end{array}$ & $\begin{array}{l}\text { Patients with } \\
\text { heart failure }\end{array}$ & $\begin{array}{l}\text { Cohort, } \\
\text { case-control } \\
\text { and post hoc } \\
\text { RCT }\end{array}$ & $\begin{array}{l}\text { Hyper } v \\
\text { normal }\end{array}$ & 9 & 12699 & 1765 & $\mathrm{HR}$ & $\begin{array}{c}1.39 \\
(1.18 \text { to } \\
1.63)\end{array}$ & 7.44E-05 & $\begin{array}{l}66 \\
(13 \\
\text { to } \\
82)\end{array}$ & 0.001 & 0.12 & $\begin{array}{l}0.89 \text { to } \\
2.07\end{array}$ & 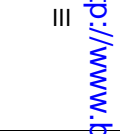 \\
\hline $\begin{array}{l}\text { Adverse outcomes } \\
\text { (mortality, MACE, } \\
\text { in stent } \\
\text { restenosis) }{ }^{46}\end{array}$ & $\begin{array}{l}\text { Patients after } \\
\mathrm{PCl}\end{array}$ & $\begin{array}{l}\text { Prospective or } \\
\text { retrospective } \\
\text { cohort }\end{array}$ & $\begin{array}{l}\text { Hyper } v \\
\text { normal }\end{array}$ & 12 & 21030 & NA & $\mathrm{RR}$ & $\begin{array}{c}1.46 \\
(1.29 \text { to } \\
1.65)\end{array}$ & 3.63E-09 & $\begin{array}{l}59(3 \\
\text { to } \\
77)\end{array}$ & $<0.001$ & NP & $\begin{array}{l}1.05 \text { to } \\
1.95\end{array}$ & IV $\underset{3}{3}$. \\
\hline $\begin{array}{l}\text { Occurrence of } \\
\text { poor outcomes }\end{array}$ & $\begin{array}{l}\text { Patients with } \\
\text { acute } \\
\text { ischaemic } \\
\text { stroke }\end{array}$ & $\begin{array}{l}\text { Prospective or } \\
\text { retrospective } \\
\text { cohort, or } \\
\text { nested } \\
\text { case-control }\end{array}$ & $\begin{array}{l}\text { Highest } v \\
\text { lowest SUA } \\
\text { category }\end{array}$ & 9 & 7932 & NA & $\mathrm{HR}$ & $\begin{array}{c}0.77 \\
(0.68 \text { to } \\
0.88)\end{array}$ & $8.12 \mathrm{E}-05$ & $\begin{array}{l}44(0 \\
\text { to } \\
73)\end{array}$ & 0.30 & NP & $\begin{array}{l}0.56 \text { to } \\
1.06\end{array}$ & $\begin{array}{l}\text { IV } \\
\text { N } \\
\text { O } \\
\text { D } \\
\text { ㄹ. } \\
\text { N }\end{array}$ \\
\hline Psoriasis $^{70}$ & $\begin{array}{l}\text { Patients with } \\
\text { psoriasis } v \\
\text { controls }\end{array}$ & Case-control & $\begin{array}{l}\text { SUA level } \\
(\mathrm{mg} / \mathrm{dl})\end{array}$ & 13 & 29037 & 1644 & $\begin{array}{l}\text { MD to } \\
\text { OR }\end{array}$ & $\begin{array}{c}4.46 \\
(1.57 \text { to } \\
12.62)\end{array}$ & 0.005 & $\begin{array}{l}98 \\
(98 \\
\text { to } \\
99)\end{array}$ & 0.41 & $<0.001$ & $\begin{array}{l}0.06 \text { to } \\
320.30\end{array}$ & 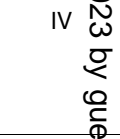 \\
\hline Severe psoriasis ${ }^{70}$ & $\begin{array}{l}\text { Patients with } \\
\text { severe } \\
\text { psoriasis } v \\
\text { controls }\end{array}$ & Case-control & $\begin{array}{l}\text { SUA level } \\
(\mathrm{mg} / \mathrm{dl})\end{array}$ & 3 & 300 & 104 & $\begin{array}{l}\text { MD to } \\
\text { OR }\end{array}$ & $\begin{array}{c}1.57 \\
(0.25 \text { to } \\
9.80)\end{array}$ & 0.64 & $\begin{array}{l}92 \\
(78 \\
\text { to } \\
96)\end{array}$ & 0.20 & $<0.001$ & $\begin{array}{l}0.00 \text { to } \\
1.52 \mathrm{E}-10\end{array}$ & 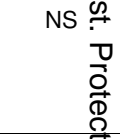 \\
\hline $\begin{array}{l}\text { Non-alcoholic fatty } \\
\text { liver disease }\end{array}$ & General & $\begin{array}{l}\text { Prospective or } \\
\text { retrospective } \\
\text { cohort, or } \\
\text { case-control }\end{array}$ & $\begin{array}{l}\text { Highest } v \\
\text { lowest SUA } \\
\text { category }\end{array}$ & 9 & 55573 & $\begin{array}{c}10 \\
581\end{array}$ & OR & $\begin{array}{c}1.92 \\
(1.59 \text { to } \\
2.31)\end{array}$ & $2.51 \mathrm{E}-11$ & $\begin{array}{l}78 \\
(61 \\
\text { to } \\
86)\end{array}$ & 0.02 & NP & $\begin{array}{l}0.99 \text { to } \\
3.74\end{array}$ & 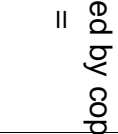 \\
\hline
\end{tabular}

$\mathrm{AF}=$ atrial fibrillation; Hyper=hyperuricemia; $\mathrm{RR}=$ relative risk; OR=odds ratio; aRR=adjusted relative risk; CVD=cardiovascular disease; aHR=adjusted hazard ratio; HR=hazard을

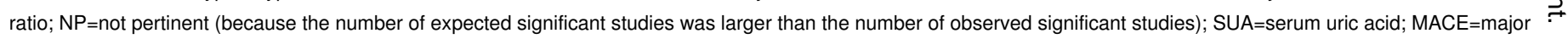
adverse cardiovascular events; $\mathrm{PCl}=$ percutaneous coronary intervention; $\mathrm{NA}=$ not available; $\mathrm{AMl}=$ acute myocardial infarction; $\mathrm{T} 2 \mathrm{DM}=$ type 2 diabetes; $\mathrm{NS}=$ not significant; $\mathrm{CKD}=$ chronic kidney disease; $\mathrm{MD}=$ mean difference; $\mathrm{SMD}=$ standardised mean difference; $\mathrm{VaD}=$ vascular dementia; $\mathrm{MCl}=$ mild cognitive impairment; $\mathrm{MS}=$ multiple sclerosis; $\mathrm{NMO}=$ neuromyelitis optica; ALS=amyotrophic lateral sclerosis; aOR=adjusted odds ratio. ${ }^{*}$ Evidence class criteria: class I (convincing): statistical significance with $\mathrm{P}<10^{-6}$, more than 1000 cases (or 
Table 1 (continued)

\begin{tabular}{|c|c|c|c|c|c|c|c|c|c|c|c|c|c|c|}
\hline Outcomes & Population & $\begin{array}{c}\text { Study design } \\
\text { included in } \\
\text { MA }\end{array}$ & Comparison & $\begin{array}{c}\text { No of } \\
\text { studies }\end{array}$ & $\begin{array}{c}\text { No of } \\
\text { participants }\end{array}$ & $\begin{array}{l}\text { No of } \\
\text { cases }\end{array}$ & $\begin{array}{l}\text { Type of } \\
\text { metric }\end{array}$ & $\begin{array}{l}\text { Relative } \\
\text { risk } \\
(95 \% \mathrm{Cl})\end{array}$ & $P$ value & $\begin{array}{c}I^{2} \\
(95 \% \\
\text { Cl) }\end{array}$ & $\begin{array}{c}P \\
\text { value } \\
\text { for } \\
\text { Egger } \\
\text { test }\end{array}$ & $\begin{array}{l}P \text { value for } \\
\text { excess } \\
\text { significance } \\
\text { test }\end{array}$ & $\begin{array}{l}95 \% \\
\text { prediction } \\
\text { interval }\end{array}$ & 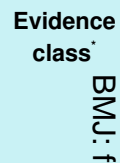 \\
\hline
\end{tabular}

$>20000$ participants for continuous outcomes), the largest component study reported statistically significant effect $(\mathrm{P}<0.05) ; 95 \%$ prediction interval excluded the null; no large $\stackrel{\vec{\oplus}}{\overrightarrow{0}}$ heterogeneity $\left(\mathrm{I}^{2}<50 \%\right)$, no evidence of small study effects $(\mathrm{P}>0.10)$ and excess significance bias $(\mathrm{P}>0.10)$; class II (highly suggestive): statistical significance with $\mathrm{P}<10^{-6}$, mor than 1000 cases (or $>20000$ participants for continuous outcomes), the largest component study reported statistically significant effect ( $<<0.05)$; class III (suggestive): statistic $\overline{8}$. significance with $\mathrm{P}<10^{-3}$, more than 1000 cases (or $>20000$ participants for continuous outcomes); class IV (weak): the remaining statistically significant associations with $\mathrm{P}<0.08$. †The heterogeneity $\left(I^{2}\right)$, Egger's test, or $95 \%$ prediction interval could not be calculated, either because data about the individual component studies were insufficient or becaus the number of studies included in meta-analyses was less than three. $¥$ Evidence was reassessed by examining the meta-analyses in depth to verify the eligibility or appropriatenes\& of the data included in analysis and errors were found. When errors and analyses were corrected, the association became non-statistically significant. 


\begin{tabular}{|c|c|c|c|c|c|c|c|c|c|c|c|c|c|c|}
\hline Outcomes & Population & $\begin{array}{c}\text { Study } \\
\text { design } \\
\text { included in } \\
\text { MA }\end{array}$ & Comparison & $\begin{array}{c}\text { No of } \\
\text { studies }\end{array}$ & $\begin{array}{c}\text { No of } \\
\text { participants }\end{array}$ & $\begin{array}{l}\text { No of } \\
\text { cases }\end{array}$ & $\begin{array}{l}\text { Type } \\
\text { of } \\
\text { metric }\end{array}$ & $\begin{array}{c}\text { Relative } \\
\text { risk } \\
(95 \% \mathrm{Cl})\end{array}$ & $P$ value & $\begin{array}{c}I^{2} \\
(95 \% \\
C I)\end{array}$ & $\begin{array}{c}P \\
\text { value } \\
\text { for } \\
\text { Egger } \\
\text { test }\end{array}$ & $\begin{array}{l}P \text { value for } \\
\text { excess } \\
\text { significance } \\
\text { test }\end{array}$ & $\begin{array}{c}95 \% \\
\text { prediction } \\
\text { interval }\end{array}$ & $\begin{array}{c}\text { Evidence } \\
\text { class }^{\star}\end{array}$ \\
\hline $\begin{array}{l}\text { Stroke } \\
\text { mortality }\end{array}$ & General & $\begin{array}{l}\text { Prospective } \\
\text { cohort }\end{array}$ & $\begin{array}{l}\text { Highest } v \\
\text { lowest SUA } \\
\text { category }\end{array}$ & 8 & 600076 & 5205 & aRR & $\begin{array}{c}1.17 \\
(0.91 \text { to } \\
1.51)\end{array}$ & 0.22 & $\begin{array}{l}84 \\
\text { (73 } \\
\text { to } \\
89)\end{array}$ & 0.44 & NP & $\begin{array}{c}0.46 \text { to } \\
2.98\end{array}$ & $\begin{array}{c}\text { NS } \\
\text { (changed } \\
\text { from I) }\end{array}$ \\
\hline $\begin{array}{l}\text { Heart failure } \\
\text { incidence }\end{array}$ & General & $\begin{array}{l}\text { Prospective } \\
\text { cohort }\end{array}$ & $\begin{array}{l}\text { Hyper } v \\
\text { normal }\end{array}$ & 5 & 427917 & $\begin{array}{c}10 \\
171\end{array}$ & $\mathrm{HR}$ & $\begin{array}{c}1.65 \\
(1.41 \text { to } \\
1.94)\end{array}$ & 1.77E-09 & $\begin{array}{c}72(7 \\
\text { to } \\
86) \\
\end{array}$ & 0.49 & 0.31 & $\begin{array}{l}1.05 \text { to } \\
2.61\end{array}$ & ॥ \\
\hline $\begin{array}{l}\text { Hypertension } \\
\text { incidence }\end{array}$ & General & $\begin{array}{l}\text { Prospective } \\
\text { cohort }\end{array}$ & $\begin{array}{l}\text { Hyper } v \\
\text { normal }\end{array}$ & 12 & 68401 & $\begin{array}{c}16 \\
132\end{array}$ & aRR & $\begin{array}{c}1.42 \\
(1.27 \text { to } \\
1.59)\end{array}$ & 2.16E-09 & $\begin{array}{l}76 \\
(53 \\
\text { to } \\
85)\end{array}$ & 0.04 & NP & $\begin{array}{c}0.98 \text { to } \\
2.05\end{array}$ & ॥ \\
\hline IFG/T2DM & General & $\begin{array}{l}\text { Prospective } \\
\text { cohort }\end{array}$ & $\begin{array}{l}\text { Highest } v \\
\text { lowest SUA } \\
\text { category }\end{array}$ & 13 & 56130 & 5629 & $\mathrm{RR}$ & $\begin{array}{c}1.62 \\
(1.47 \text { to } \\
1.77)\end{array}$ & $1.25 \mathrm{E}-22$ & $\begin{array}{l}0(0 \\
\text { to } \\
49)\end{array}$ & 0.07 & NP & $\begin{array}{c}1.45 \text { to } \\
1.79\end{array}$ & ॥ \\
\hline $\begin{array}{l}\text { CKD } \\
\text { incidence }\end{array}$ & $\begin{array}{l}\text { Middle } \\
\text { aged } \\
\text { populations }\end{array}$ & $\begin{array}{l}\text { Prospective } \\
\text { cohort }\end{array}$ & $\begin{array}{l}1 \mathrm{mg} / \mathrm{dL} \text { SUA } \\
\text { increase }\end{array}$ & 12 & 78205 & 2793 & $\mathrm{RR}$ & $\begin{array}{c}1.19 \\
(1.12 \text { to } \\
1.25)\end{array}$ & 1.26E-09 & $\begin{array}{l}67 \\
(34 \\
\text { to } \\
80)\end{array}$ & 0.10 & 0.15 & $\begin{array}{c}0.99 \text { to } \\
1.42\end{array}$ & ॥ \\
\hline CHD mortality & General & $\begin{array}{l}\text { Prospective } \\
\text { cohort }\end{array}$ & $\begin{array}{l}\text { Hyper } v \\
\text { normal }\end{array}$ & 13 & 876584 & $\begin{array}{c}24 \\
198\end{array}$ & aRR & $\begin{array}{c}1.27 \\
(1.16 \text { to } \\
1.39)\end{array}$ & 3.47E-07 & $\begin{array}{l}65 \\
(36 \\
\text { to } \\
78)\end{array}$ & 0.10 & NP & $\begin{array}{c}0.96 \text { to } \\
1.69\end{array}$ & ॥ \\
\hline $\begin{array}{l}\text { All cause } \\
\text { mortality }\end{array}$ & $\begin{array}{l}\text { Patients } \\
\text { with HF }\end{array}$ & $\begin{array}{l}\text { Prospective } \\
\text { cohort }\end{array}$ & $\begin{array}{l}\text { Hyper } v \\
\text { normal }\end{array}$ & 6 & 9608 & 1474 & $\mathrm{HR}$ & $\begin{array}{c}2.38 \\
(1.59 \text { to } \\
3.56)\end{array}$ & $2.98 \mathrm{E}-05$ & $\begin{array}{l}88 \\
(77 \\
\text { to } \\
92)\end{array}$ & 0.05 & 0.39 & $\begin{array}{c}0.61 \text { to } \\
9.35\end{array}$ & $\begin{array}{c}\text { III } \\
\text { (changed } \\
\text { from II) }\end{array}$ \\
\hline
\end{tabular}

SUA=serum uric acid; aRR=adjusted relative risk; $\mathrm{NP}=$ not pertinent (because the number of expected significant studies was larger than the number of observed significant studies); NS=not significant; Hyper=hyperuricemia; HR=hazard ratio; IFG=impaired fasting glucose; T2DM=type 2 diabetes; RR=relative risk; CKD=chronic kidney disease; $\mathrm{CHD}=$ coronary heart disease; $\mathrm{HF}=$ heart failure; $\mathrm{OR}=$ odds ratio; $\mathrm{NA}=$ not available. ${ }^{*}$ Evidence class criteria: class I (convincing): statistical significance with $\mathrm{P}<10^{-6}$, more than 1000 cases (or $>20000$ participants for continuous outcomes), the largest component study reported statistically significant effect ( $\left.<<0.05\right)$; $95 \%$ prediction interval excluded the null value; no large heterogeneity $\left(I^{2}<50 \%\right)$, no evidence of small study effects $(P>0.10)$ and excess significance bias $(P>0.10)$; class II (highly suggestive): statistical significance with $\mathrm{P}<10^{-6}$, more than 1000 cases (or $>20000$ participants for continuous outcomes), the largest component study reported statistically significant effect $(\mathrm{P}<0.05)$; class III (suggestive): statistical significance with $\mathrm{P}<10^{-3}$, more than 1000 cases (or $>20000$ participants for continuous outcomes). $\dagger$ The heterogeneity $\left(\mathrm{I}^{2}\right)$, Egger's test, and $95 \%$ prediction interval could not be calculated, because the number of studies included in meta-analyses was less than three. 


\begin{tabular}{|c|c|c|c|c|c|c|c|c|c|c|c|}
\hline Outcomes & Population & $\begin{array}{c}\text { SUA } \\
\text { lowering } \\
\text { treatment }\end{array}$ & $\begin{array}{l}\text { No of } \\
\text { studies }\end{array}$ & $\begin{array}{l}\text { No of } \\
\text { participants }\end{array}$ & $\begin{array}{l}\text { Type of } \\
\text { metric }\end{array}$ & $\begin{array}{l}\text { Relative risk } \\
\qquad(95 \% \mathrm{Cl})\end{array}$ & P value & $\begin{array}{l}\mathrm{I}^{2}(95 \% \\
\quad \mathrm{CI})\end{array}$ & $\begin{array}{l}\text { P value } \\
\text { for } \\
\text { Egger's } \\
\text { test }\end{array}$ & $\begin{array}{l}P \text { value for } \\
\text { excess } \\
\text { significance } \\
\text { test }\end{array}$ & $\begin{array}{c}95 \% \\
\text { prediction } \\
\text { interval }\end{array}$ \\
\hline \multicolumn{12}{|l|}{ Kidney disorders } \\
\hline $\begin{array}{l}\text { Recurrence of } \\
\text { nephrolithiasis }{ }^{\star} t^{86}\end{array}$ & $\begin{array}{l}\text { Patients with } \\
\text { nephrolithiasis }\end{array}$ & Allopurinol & 2 & 152 & $\mathrm{RR}$ & $\begin{array}{c}0.59(0.42 \text { to } \\
0.84)\end{array}$ & $2.90 \mathrm{E}-03$ & NA & NA & 0.39 & NA \\
\hline $\begin{array}{l}\text { Recurrence of } \\
\text { nephrolithiasis } \dagger^{86}\end{array}$ & $\begin{array}{l}\text { Patients with } \\
\text { nephrolithiasis }\end{array}$ & Thiazides & 5 & 300 & $\mathrm{RR}$ & $\begin{array}{c}0.52(0.39 \text { to } \\
0.69)\end{array}$ & $9.00 \mathrm{E}-06$ & 0 (0 to 64$)$ & 0.06 & 0.11 & $\begin{array}{c}0.33 \text { to } \\
0.82\end{array}$ \\
\hline $\begin{array}{l}\text { Recurrence of } \\
\text { nephrolithiasis }^{\dagger 86}\end{array}$ & $\begin{array}{l}\text { Patients with } \\
\text { nephrolithiasis }\end{array}$ & Citrates & 4 & 197 & $\mathrm{RR}$ & $\begin{array}{c}0.26(0.15 \text { to } \\
0.45)\end{array}$ & $2.84 \mathrm{E}-06$ & 0 (0 to 68$)$ & 0.19 & NP & $\begin{array}{c}0.08 \text { to } \\
0.88\end{array}$ \\
\hline Serum creatinine ${ }^{87}$ & General & $\begin{array}{l}\text { All active } \\
\text { treatment }\end{array}$ & 9 & 580 & $\begin{array}{l}\text { SMD to } \\
\text { OR }\end{array}$ & $\begin{array}{c}0.10(0.03 \text { to } \\
0.39)\end{array}$ & 4.64E-04 & $\begin{array}{c}93(90 \text { to } \\
95)\end{array}$ & 0.39 & NP & $\begin{array}{c}0.01 \text { to } \\
13.21\end{array}$ \\
\hline Serum creatinine ${ }^{88}$ & Patients with CKD & Allopurinol & 6 & 354 & $\begin{array}{l}\text { MD to } \\
\text { OR }\end{array}$ & $\begin{array}{c}0.16(0.08 \text { to } \\
0.34)\end{array}$ & $1.00 \mathrm{E}-06$ & $\begin{array}{c}70(0 \text { to } \\
85)\end{array}$ & 0.01 & 0.59 & $\begin{array}{c}0.02 \text { to } \\
1.76\end{array}$ \\
\hline eGFR ${ }^{87}$ & General & $\begin{array}{l}\text { All active } \\
\text { treatment }\end{array}$ & 3 & 218 & $\begin{array}{l}\text { SMD to } \\
\text { OR }\end{array}$ & $\begin{array}{c}2.22(1.21 \text { to } \\
4.06)\end{array}$ & $9.79 \mathrm{E}-03$ & $\begin{array}{c}29(0 \text { to } \\
80)\end{array}$ & 0.24 & NP & $\begin{array}{l}0.01 \text { to } \\
497.40\end{array}$ \\
\hline eGFR ${ }^{89}$ & $\begin{array}{l}\text { Patients with CKD } \\
\text { or decreased } \\
\text { kidney function }\end{array}$ & Allopurinol & 5 & 346 & $\begin{array}{l}\text { MD to } \\
\text { OR }\end{array}$ & $\begin{array}{c}1.18(0.97 \text { to } \\
1.42)\end{array}$ & 0.09 & $0(0$ to 64$)$ & 0.29 & NP & $\begin{array}{c}0.86 \text { to } \\
1.60\end{array}$ \\
\hline Proteinuria $^{89}$ & $\begin{array}{l}\text { Patients with CKD } \\
\text { or decreased } \\
\text { kidney function }\end{array}$ & Allopurinol & 5 & 250 & $\begin{array}{l}\text { MD to } \\
\text { OR }\end{array}$ & $\begin{array}{c}0.91 \text { (0.73 to } \\
1.12)\end{array}$ & 0.40 & 0 (0 to 64$)$ & 0.42 & NP & $\begin{array}{c}0.64 \text { to } \\
1.28\end{array}$ \\
\hline Blood urea nitrogen ${ }^{88}$ & Patients with CKD & Allopurinol & 3 & 169 & $\begin{array}{l}\text { MD to } \\
\text { OR }\end{array}$ & $\begin{array}{c}0.18(0.10 \text { to } \\
0.32)\end{array}$ & 1.47E-08 & $0(0$ to 73$)$ & 0.88 & 0.67 & $\begin{array}{c}0.01 \text { to } \\
7.16\end{array}$ \\
\hline $\begin{array}{l}\text { End stage renal } \\
\text { disease }^{88}\end{array}$ & Patients with CKD & Allopurinol & 5 & 267 & $\mathrm{RR}$ & $\begin{array}{c}0.33(0.21 \text { to } \\
0.51)\end{array}$ & $1.38 \mathrm{E}-06$ & $0(0$ to 64$)$ & 0.01 & 0.07 & $\begin{array}{c}0.16 \text { to } \\
0.68\end{array}$ \\
\hline \multicolumn{12}{|l|}{ Endothelial function } \\
\hline $\begin{array}{l}\text { Flow mediated } \\
\text { dilatation }^{90}\end{array}$ & $\begin{array}{l}\text { Population with } \\
\text { vascular disease } \\
\text { or risk factors }\end{array}$ & $\begin{array}{l}\text { Allopurinol } \\
\text { or } \\
\text { oxypurinol }\end{array}$ & 5 & 144 & $\begin{array}{l}\text { MD to } \\
\text { OR }\end{array}$ & $\begin{array}{c}4.38(1.85 \text { to } \\
10.38)\end{array}$ & $8.76 \mathrm{E}-04$ & $\begin{array}{c}60(0 \text { to } \\
83)\end{array}$ & 0.23 & 0.24 & $\begin{array}{l}0.27 \text { to } \\
70.69\end{array}$ \\
\hline Forearm blood flow ${ }^{90}$ & $\begin{array}{l}\text { Population with } \\
\text { vascular disease } \\
\text { or risk factors }\end{array}$ & $\begin{array}{l}\text { Allopurinol } \\
\text { or } \\
\text { oxypurinol }\end{array}$ & 5 & 148 & $\begin{array}{l}\text { MD to } \\
\text { OR }\end{array}$ & $\begin{array}{c}2.69(1.22 \text { to } \\
5.93)\end{array}$ & 0.014 & $\begin{array}{c}53(0 \text { to } \\
81)\end{array}$ & 0.09 & 0.61 & $\begin{array}{l}0.24 \text { to } \\
30.73\end{array}$ \\
\hline \multicolumn{12}{|l|}{ Mortality } \\
\hline $\begin{array}{l}\text { Death during } \\
\text { neonatal period or } \\
\text { infancy }^{92}\end{array}$ & All infants & Allopurinol & 3 & 114 & $\mathrm{RR}$ & $\begin{array}{c}0.87(0.43 \text { to } \\
1.75)\end{array}$ & 0.71 & $\begin{array}{c}34(0 \text { to } \\
81)\end{array}$ & 0.49 & NP & $\begin{array}{l}0.01 \text { to } \\
952.4\end{array}$ \\
\hline $\begin{array}{l}\text { Death during } \\
\text { neonatal period or } \\
\text { infancy }^{\dagger 92}\end{array}$ & $\begin{array}{l}\text { Infants with severe } \\
\text { hypoxic-ischaemic } \\
\text { encephalopathy }\end{array}$ & Allopurinol & 2 & 41 & $\mathrm{RR}$ & $\begin{array}{c}0.92(0.39 \text { to } \\
2.15)\end{array}$ & 0.86 & NA & NA & NP & NA \\
\hline $\begin{array}{l}\text { Death or serve } \\
\text { neurodevelopmental } \\
\text { disability }\end{array}$ & All infants & Allopurinol & 3 & 110 & $\mathrm{RR}$ & $\begin{array}{c}0.85(0.63 \text { to } \\
1.15)\end{array}$ & 0.29 & $0(0$ to 73$)$ & 0.12 & NP & $\begin{array}{l}0.12 \text { to } \\
5.98\end{array}$ \\
\hline $\begin{array}{l}\text { Death or serve } \\
\text { neurodevelopmental } \\
\text { disability }^{\dagger 92}\end{array}$ & $\begin{array}{l}\text { Infants with severe } \\
\text { hypoxic-ischaemic } \\
\text { encephalopathy }\end{array}$ & Allopurinol & 2 & 41 & $\mathrm{RR}$ & $\begin{array}{c}0.93(0.67 \text { to } \\
1.30)\end{array}$ & 0.68 & NA & NA & NP & NA \\
\hline \multicolumn{12}{|l|}{ Other outcomes } \\
\hline Severe quadriplegia ${ }^{92}$ & $\begin{array}{l}\text { Surviving infants } \\
\text { with } \\
\text { hypoxic-ischaemic } \\
\text { encephalopathy }\end{array}$ & Allopurinol & 3 & 73 & $\mathrm{RR}$ & $\begin{array}{c}0.58(0.27 \text { to } \\
1.26)\end{array}$ & 0.17 & 0 (0 to 73$)$ & 0.69 & NP & $\begin{array}{l}0.01 \text { to } \\
86.99\end{array}$ \\
\hline $\begin{array}{l}\text { Seizures in neonatal } \\
\text { period }^{92}\end{array}$ & $\begin{array}{l}\text { Surviving infants } \\
\text { with } \\
\text { hypoxic-ischaemic } \\
\text { encephalopathy }\end{array}$ & Allopurinol & 3 & 114 & $\mathrm{RR}$ & $\begin{array}{c}0.98(0.84 \text { to } \\
1.15)\end{array}$ & 0.81 & 0 (0 to 73$)$ & 0.15 & NP & $\begin{array}{l}0.35 \text { to } \\
2.79\end{array}$ \\
\hline 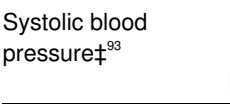 & $\begin{array}{l}\text { Patients with } \\
\text { increased SUA or } \\
\text { kidney dysfunction }\end{array}$ & Allopurinol & 10 & 738 & $\begin{array}{l}\mathrm{MD}(\mathrm{mm} \\
\mathrm{Hg})\end{array}$ & $\begin{array}{c}-3.33(-5.25 \\
\text { to }-1.42)\end{array}$ & 0.001 & $\begin{array}{c}87 \text { (79 to } \\
91)\end{array}$ & 0.60 & NP & $\begin{array}{c}-13.61 \text { to } \\
6.94\end{array}$ \\
\hline
\end{tabular}




\section{Table 3 (continued)}

\begin{tabular}{|c|c|c|c|c|c|c|c|c|c|c|c|}
\hline Outcomes & Population & $\begin{array}{c}\text { SUA } \\
\text { lowering } \\
\text { treatment }\end{array}$ & $\begin{array}{c}\text { No of } \\
\text { studies }\end{array}$ & $\begin{array}{c}\text { No of } \\
\text { participants }\end{array}$ & $\begin{array}{l}\text { Type of } \\
\text { metric }\end{array}$ & $\begin{array}{c}\text { Relative risk } \\
(95 \% \mathrm{Cl})\end{array}$ & $P$ value & $\begin{array}{c}I^{2}(95 \% \\
\text { CI) }\end{array}$ & $\begin{array}{l}P \text { value } \\
\text { for } \\
\text { Egger's } \\
\text { test }\end{array}$ & $\begin{array}{l}\text { P value for } \\
\text { excess } \\
\text { significance } \\
\text { test }\end{array}$ & $\begin{array}{c}95 \% \\
\text { prediction } \\
\text { interval }\end{array}$ \\
\hline 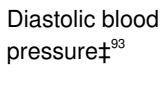 & $\begin{array}{l}\text { Patients with } \\
\text { increased SUA or } \\
\text { kidney dysfunction }\end{array}$ & Allopurinol & 10 & 738 & $\begin{array}{c}\mathrm{MD}(\mathrm{mm} \\
\mathrm{Hg})\end{array}$ & $\begin{array}{c}-1.29(-2.48 \\
\text { to }-0.10)\end{array}$ & 0.03 & $\begin{array}{c}82(68 \text { to } \\
88)\end{array}$ & 0.38 & NP & $\begin{array}{c}-8.22 \text { to } \\
5.65\end{array}$ \\
\hline
\end{tabular}

SUA=serum uric acid; RR=relative risk; $N A=$ not applicable (did not calculate with only 2 studies); $N P=$ not pertinent (because the number of expected significant

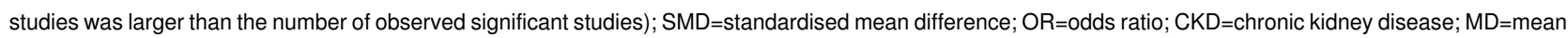
difference; eGFR=estimated glomerular filtration rate.

*The heterogeneity $\left({ }^{2}\right)$, Egger's test, or $95 \%$ prediction interval could not be calculated, because the number of studies included in meta-analyses was less than 3.

†The strength of evidence was graded based on the evidence based practice centre approach (conceptually similar to the GRADE ranking system); recurrence of nephrolithiasis (with allopurinol, thiazides, or citrates treatment) was all considered with moderate evidence in original meta-analyses. $\ddagger$ Meta-analyses included one prospective study. 


\begin{tabular}{|c|c|c|c|c|c|c|c|c|}
\hline Outcomes & Population & $\begin{array}{l}\text { No/No of } \\
\text { Events (No of } \\
\text { studies)* }\end{array}$ & Genetic instruments (GI) & $\begin{array}{c}\text { SUA } \\
\text { variance } \\
\left(R^{2}\right) \\
\text { explained } \\
\text { by } \mathrm{GI}(\%)\end{array}$ & $\begin{array}{l}\text { Type of } \\
\text { metric }\end{array}$ & $\begin{array}{l}\text { Estimate of effect } \\
\qquad(95 \% \mathrm{Cl})\end{array}$ & $P$ value & $\begin{array}{c}\text { Statistical } \\
\text { power† }\end{array}$ \\
\hline \multicolumn{9}{|c|}{ Anthropometric variables } \\
\hline $\begin{array}{l}\text { Appendicular lean } \\
\text { mass }(\mathrm{kg})^{94}\end{array}$ & UK & 3953 & rs737267 in SCL2A9 & NA & $\beta$ & $0.013(\mathrm{NA})$ & 0.51 & NA \\
\hline Fat mass $(\mathrm{kg})^{95}$ & Switzerland & 6184 & rs6855911 in SCL2A9 & 3.2 & $\beta$ & $0.05(-0.10$ to 0.19$)$ & 0.52 & 0.07 \\
\hline $\begin{array}{l}\text { Body mass index } \\
\left(\mathrm{kg} / \mathrm{m}^{2}\right)^{96}\end{array}$ & Europe & $127600(64)^{\star}$ & $\begin{array}{l}\text { Genetic risk score of } 31 \text { SUA } \\
\text { related SNPs }\end{array}$ & 4.2 & $\mathrm{MD} \ddagger$ & $\begin{array}{c}-0.0003(-0.0008 \text { to } \\
0.0002)\end{array}$ & NA & NA \\
\hline $\begin{array}{l}\text { Waist circumference } \\
(\mathrm{cm})^{95}\end{array}$ & Switzerland & 6184 & rs6855911 in SCL2A9 & 3.2 & $\beta$ & $0.08(-0.05$ to 0.21$)$ & 0.24 & 0.06 \\
\hline $\begin{array}{l}\text { BMD in femoral neck } \\
\left(\mathrm{g} / \mathrm{cm}^{2}\right)^{97}\end{array}$ & USA & 2501 & $\begin{array}{l}\text { Genetic risk score of } 5 \text { SUA } \\
\text { related SNPs }\end{array}$ & 3.3 & $\beta$ & $-0.27(-0.58$ to 0.03$)$ & 0.08 & 0.07 \\
\hline $\mathrm{BMD}$ in L1- L4 $\left(\mathrm{g} / \mathrm{cm}^{2}\right)^{98}$ & China & 1667 & $\begin{array}{l}\text { Genetic risk score of } 5 \text { SUA } \\
\text { related SNPs }\end{array}$ & 1.8 & $\beta$ & $0.39(-0.26$ to 0.98$)$ & 0.26 & 0.19 \\
\hline BMD in spine $\left(\mathrm{g} / \mathrm{cm}^{2}\right)^{97}$ & USA & 2501 & $\begin{array}{l}\text { Genetic risk score of } 5 \text { SUA } \\
\text { related SNPs }\end{array}$ & 3.3 & $\beta$ & $0.08(-0.32$ to 0.48$)$ & 0.68 & 0.18 \\
\hline $\begin{array}{l}\text { BMD in total femur } \\
\left(\mathrm{g} / \mathrm{cm}^{2}\right)^{97}\end{array}$ & USA & 2501 & $\begin{array}{l}\text { Genetic risk score of } 5 \text { SUA } \\
\text { related SNPs }\end{array}$ & 3.3 & $\beta$ & $-0.29(-0.60$ to 0.01$)$ & 0.06 & 0.11 \\
\hline $\begin{array}{l}\text { BMD in total hip } \\
\left(\mathrm{g} / \mathrm{cm}^{2}\right)^{98}\end{array}$ & China & 1667 & $\begin{array}{l}\text { Genetic risk score of } 5 \text { SUA } \\
\text { related SNPs }\end{array}$ & 1.8 & $\beta$ & $0.19(-0.36$ to 0.74$)$ & 0.50 & 0.19 \\
\hline \multicolumn{9}{|c|}{ Cardiovascular outcomes } \\
\hline Arrhythmia ${ }^{99}$ & Germany & $3060 / 444$ & $\begin{array}{l}\text { Genetic risk score of } 8 \text { SUA } \\
\text { related SNPs }\end{array}$ & NA & OR & 0.98 (0.88 to 1.08$)$ & 0.64 & $0.05 \S$ \\
\hline Atrial fibrillation ${ }^{99}$ & Germany & $3060 / 368$ & $\begin{array}{l}\text { Genetic risk score of } 8 \text { SUA } \\
\text { related SNPs }\end{array}$ & NA & OR & $1.03(0.93$ to 1.15$)$ & 0.57 & $0.05 \S$ \\
\hline Cardiomyopathy ${ }^{99}$ & Germany & $3060 / 316$ & $\begin{array}{l}\text { Genetic risk score of } 8 \text { SUA } \\
\text { related SNPs }\end{array}$ & NA & OR & 1.00 (0.89 to 1.12$)$ & 0.93 & $0.05 \S$ \\
\hline $\begin{array}{l}\text { Coronary heart disease } \\
96\end{array}$ & Europe & $\begin{array}{c}206822 / 65877 \\
(58)^{*}\end{array}$ & $\begin{array}{l}\text { Genetic risk score of } 31 \text { SUA } \\
\text { related SNPs }\end{array}$ & 4.2 & OR & 1.05 (0.92 to 1.18$)$ & 0.49 & 0.57 \\
\hline Heart failure ${ }^{100}$ & Pakistan & $\begin{array}{c}22926 / 4526 \\
(2)^{*}\end{array}$ & $\begin{array}{l}\text { Genetic risk score of } 14 \text { SUA } \\
\text { related SNPs }\end{array}$ & 3.1 & OR & $1.07(0.88$ to 1.30$)$ & 0.51 & 0.11 \\
\hline $\begin{array}{l}\text { Ischaemic heart } \\
\text { disease }^{101}\end{array}$ & Denmark & $\begin{array}{c}68674 / 3742 \\
(2)^{*}\end{array}$ & rs7442295 in SCL2A9 & 2.2 & $\mathrm{HR}$ & 0.93 (0.79 to 1.09$)$ & 0.38 & 0.10 \\
\hline Hypertension $^{99}$ & Germany & $3060 / 2225$ & $\begin{array}{l}\text { Genetic risk score of } 8 \text { SUA } \\
\text { related SNPs }\end{array}$ & NA & OR & $0.98(0.90$ to 1.06$)$ & 0.56 & $0.05 \S$ \\
\hline Ischaemic stroke ${ }^{100}$ & Pakistan & $\begin{array}{c}82091 / 14779 \\
(2)^{\star}\end{array}$ & $\begin{array}{l}\text { Genetic risk score of } 14 \text { SUA } \\
\text { related SNPs }\end{array}$ & 3.1 & OR & 0.99 (0.88 to 1.12$)$ & 0.93 & 0.05 \\
\hline $\begin{array}{l}\text { Peripheral vascular } \\
\text { disease }^{99}\end{array}$ & Germany & $3060 / 295$ & $\begin{array}{l}\text { Genetic risk score of } 8 \text { SUA } \\
\text { related SNPs }\end{array}$ & NA & OR & $0.92(0.82$ to 1.04$)$ & 0.18 & $0.06 \S$ \\
\hline Valve disease ${ }^{99}$ & Germany & $3060 / 538$ & $\begin{array}{l}\text { Genetic risk score of } 8 \text { SUA } \\
\text { related SNPs }\end{array}$ & NA & OR & $1.08(0.99$ to 1.19$)$ & 0.10 & $0.07 \S$ \\
\hline $\begin{array}{l}\text { Diabetic macrovascular } \\
\text { disease }^{103}\end{array}$ & $\begin{array}{l}\text { Patients with } \\
\text { T2DM in China }\end{array}$ & 3207 & $\begin{array}{l}\text { Genetic risk score of } 3 \text { SUA } \\
\text { related SNPs }\end{array}$ & NA & OR & 1.18 (1.06 to 1.33$)$ & 0.004 & NA \\
\hline ClMT $(\mathrm{mm})^{102}$ & Finland (male) & 1985 & rs13129697 in SCL2A9 & NA & $\beta$ & $<0.0001$ (NA) & 0.99 & NA \\
\hline $\begin{array}{l}\text { Arterial stiffness } \\
\text { (internal diameter of } \\
\text { carotid artery) }(\mathrm{mm})^{104}\end{array}$ & Italy & 449 & rs734553 in SLC2A9 & NA & $\beta$ & 0.48 (NA) & 0.003 & NA \\
\hline $\begin{array}{l}\text { Diastolic blood } \\
\text { pressure }(\mathrm{mm} \mathrm{Hg})^{96}\end{array}$ & Europe & $89667(37)^{\star}$ & $\begin{array}{l}\text { Genetic risk score of } 31 \text { SUA } \\
\text { related SNPs }\end{array}$ & 4.2 & MD $\ddagger$ & 0.005 (0.003 to 0.007$)$ & NA & NA \\
\hline $\begin{array}{l}\text { Systolic blood pressure } \\
(\mathrm{mm} \mathrm{Hg})^{96}\end{array}$ & Europe & $89667(37)^{*}$ & $\begin{array}{l}\text { Genetic risk score of } 31 \text { SUA } \\
\text { related SNPs }\end{array}$ & 4.2 & MD $\ddagger$ & 0.005 (0.003 to 0.006$)$ & NA & NA \\
\hline \multicolumn{9}{|l|}{ Metabolic disorders } \\
\hline Type 2 diabetes ${ }^{100}$ & Pakistan & $\begin{array}{c}110452 / 26488 \\
(2)^{\star}\end{array}$ & $\begin{array}{l}\text { Genetic risk score of } 14 \text { SUA } \\
\text { related SNPs }\end{array}$ & 3.1 & OR & 0.95 (0.86 to 1.05$)$ & 0.28 & 0.24 \\
\hline
\end{tabular}


Table 4 (continued)

\begin{tabular}{|c|c|c|c|c|c|c|c|c|}
\hline Outcomes & Population & $\begin{array}{l}\text { No/No of } \\
\text { Events (No of } \\
\text { studies) }\end{array}$ & Genetic instruments (GI) & $\begin{array}{c}\text { SUA } \\
\text { variance } \\
\left(R^{2}\right) \\
\text { explained } \\
\text { by GI }(\%)\end{array}$ & $\begin{array}{l}\text { Type of } \\
\text { metric }\end{array}$ & $\begin{array}{l}\text { Estimate of effect } \\
\qquad(95 \% \mathrm{Cl})\end{array}$ & $P$ value & $\begin{array}{c}\text { Statistical } \\
\text { power† }\end{array}$ \\
\hline Diabetes $^{105}$ & Europe & $\begin{array}{c}165482 / 41508 \\
(2)^{*}\end{array}$ & $\begin{array}{l}\text { Genetic risk score of } 24 \text { SUA } \\
\text { related SNPs }\end{array}$ & 4.0 & OR & 0.99 (0.92 to 1.06$)$ & 0.79 & 0.06 \\
\hline $\begin{array}{l}\text { Fasting glucose } \\
(\mathrm{mmol} / \mathrm{L})^{96}\end{array}$ & Europe & $57397(28)^{\star}$ & $\begin{array}{l}\text { Genetic risk score of } 31 \text { SUA } \\
\text { related SNPs }\end{array}$ & 4.2 & MD $\ddagger$ & $\begin{array}{c}-0.001(-0.003 \text { to } \\
0.001)\end{array}$ & NA & NA \\
\hline Fasting insulin $\Upsilon^{106}$ & USA & $19899(5)^{\star}$ & $\begin{array}{l}\text { Genetic risk score of } 8 \text { SUA } \\
\text { related SNPs }\end{array}$ & 6.0 & Z statistic & $-0.015(\mathrm{NA})$ & 0.99 & NA \\
\hline Metabolic syndrome $^{107}$ & China & 7827 & $\begin{array}{l}\text { Genetic risk score of } 2 \text { SNPs } \\
\text { (rs11722228 in SLC2A9 and } \\
\text { rs2231142 in } A B C G 2)\end{array}$ & 2.1 & OR & 1.03 (0.98 to 1.09$)$ & 0.23 & NA \\
\hline \multicolumn{9}{|l|}{ Kidney disorders } \\
\hline $\begin{array}{l}\text { Chronic kidney } \\
\text { disease }^{106}\end{array}$ & USA & $\begin{array}{c}23387 / 3092 \\
(5)^{*}\end{array}$ & $\begin{array}{l}\text { Genetic risk score of } 8 \text { SUA } \\
\text { related SNPs }\end{array}$ & 6.0 & OR & 1.20 (0.96 to 1.50$)$ & 0.12 & 0.70 \\
\hline Acute kidney injury ${ }^{108}$ & USA & $7553 / 823$ & $\begin{array}{l}\text { Genetic risk score of } 8 \text { SUA } \\
\text { related SNPs }\end{array}$ & 6.0 & $\mathrm{HR}$ & $1.01(0.77$ to 1.34$)$ & 0.92 & 0.05 \\
\hline Adverse renal events $^{109}$ & Italy & $755 / 244$ & rs734553 in GLUT9 & NA & $\mathrm{HR}$ & 2.35 (1.25 to 4.42$)$ & 0.01 & NA \\
\hline $\begin{array}{l}\text { Log eGFR } \\
\left(\mathrm{mL} / \mathrm{min} / 1.73 \mathrm{~m}^{2}\right)^{106}\end{array}$ & USA & $23844(5)^{\star}$ & $\begin{array}{l}\text { Genetic risk score of } 8 \text { SUA } \\
\text { related SNPs }\end{array}$ & 6.0 & $\beta$ & $0.001(-0.01$ to 0.02$)$ & 0.91 & 0.05 \\
\hline $\begin{array}{l}\text { serum creatinine } \\
(\mathrm{mmol} / \mathrm{L})^{110}\end{array}$ & $\begin{array}{l}\text { Europe } \\
\text { (Caucasian) }\end{array}$ & $7979(2)^{*}$ & $\begin{array}{l}\text { Genetic risk score of } 5 \text { SUA } \\
\text { related SNPs }\end{array}$ & 2.3 & $\beta$ & $\begin{array}{c}-19.23(-40.32 \text { to } \\
1.86)\end{array}$ & 0.07 & NA \\
\hline $\begin{array}{l}\text { Albumin/creatinine } \\
\text { ratio }^{129}\end{array}$ & $\begin{array}{l}\text { USA (Indian } \\
\text { American) }\end{array}$ & $3604(3)^{*}$ & $\begin{array}{l}\text { Genetic risk score of } 5 \text { SUA } \\
\text { related SNPs }\end{array}$ & 5.3 & $\begin{array}{l}\text { Residual } \\
\text { variance" }\end{array}$ & Overall $P>0.05$ & & NA \\
\hline \multicolumn{9}{|c|}{ Neurocognitive disorders } \\
\hline Parkinson's disease ${ }^{116}$ & UK & $1815 / 1061$ & $\begin{array}{l}\text { Genetic risk score of } 8 \text { SUA } \\
\text { related SNPs }\end{array}$ & NA & OR & 1.55 (1.10 to 2.18$)$ & 0.01 & $0.59 \S$ \\
\hline \multirow{5}{*}{$\begin{array}{l}\text { Age at onset of } \\
\text { Parkinson's disease }\end{array}$} & \multirow{5}{*}{ Europe } & \multirow[t]{5}{*}{$664(3)^{*}$} & 4 SNPs in SCL2A9 & NA & \multirow[t]{5}{*}{$\beta$} & \multicolumn{3}{|c|}{ Null after multiple testing correction } \\
\hline & & & rs737267 & NA & & $3.10(0.17$ to 6.03$)$ & 0.04 & NA \\
\hline & & & rs6449213 & NA & & $-1.18(-4.96$ to 2.59$)$ & 0.54 & \\
\hline & & & rs1014290 & NA & & $-4.56(-8.13$ to -1.00$)$ & 0.01 & \\
\hline & & & rs733175 & NA & & $3.59(0.67$ to 6.51$)$ & 0.02 & \\
\hline \multirow{2}{*}{$\begin{array}{l}\text { Lifetime anxiety } \\
\text { disorders }^{113}\end{array}$} & \multirow[t]{2}{*}{ Switzerland } & \multirow[t]{2}{*}{3716} & \multirow[t]{2}{*}{ rs6855911 in SLC2A9 } & \multirow[t]{2}{*}{3.2} & OR (male) & $1.40(1.07$ to 1.84$)$ & 0.02 & 0.11 \\
\hline & & & & & $\begin{array}{c}\text { OR } \\
\text { (female) }\end{array}$ & 0.97 (0.80 to 1.17$)$ & 0.73 & 0.05 \\
\hline \multirow{2}{*}{$\begin{array}{l}\text { Current anxiety } \\
\text { disorders }^{113}\end{array}$} & \multirow[t]{2}{*}{ Switzerland } & \multirow[t]{2}{*}{3716} & \multirow[t]{2}{*}{ rs6855911 in SLC2A9 } & \multirow[t]{2}{*}{3.2} & OR (male) & $1.42(0.99$ to 2.03$)$ & 0.06 & 0.12 \\
\hline & & & & & $\begin{array}{c}\text { OR } \\
\text { (female) }\end{array}$ & $0.84(0.66$ to 1.06$)$ & 0.14 & 0.07 \\
\hline \multirow[t]{2}{*}{$\begin{array}{l}\text { Memory } \\
\text { performance }^{114}\end{array}$} & $\begin{array}{l}\text { Europe: } \\
\text { Population } 1 \\
\end{array}$ & 1091 & 4 SNPs in SCL2A9 & NA & $\beta$ & Overall $\mathrm{P}<0.05$ & & NA \\
\hline & $\begin{array}{l}\text { Europe: } \\
\text { Population } 2\end{array}$ & 1066 & 4 SNPs in SCL2A9 & NA & $\beta$ & Overall $\mathrm{P}>0.05$ & & NA \\
\hline \multicolumn{9}{|l|}{ Metabolites } \\
\hline $\begin{array}{l}\text { High density lipoprotein } \\
\text { cholesterol }(\mathrm{mmol} / \mathrm{L})^{96}\end{array}$ & Europe & $196621(68)^{*}$ & $\begin{array}{l}\text { Genetic risk score of } 31 \text { SUA } \\
\text { related SNPs }\end{array}$ & 4.2 & MD $\ddagger$ & $\begin{array}{c}-0.008(-0.010 \text { to } \\
-0.006)\end{array}$ & NA & NA \\
\hline $\begin{array}{l}\text { Low density lipoprotein } \\
\text { cholesterol }(\mathrm{mmol} / \mathrm{L})^{96}\end{array}$ & Europe & $196621(68)^{*}$ & $\begin{array}{l}\text { Genetic risk score of } 31 \text { SUA } \\
\text { related SNPs }\end{array}$ & 4.2 & MD $\ddagger$ & $\begin{array}{c}-0.001(-0.003 \text { to } \\
0.001)\end{array}$ & NA & NA \\
\hline $\begin{array}{l}\text { Total cholesterol } \\
(\mathrm{mmol} / \mathrm{L})^{96}\end{array}$ & Europe & $196621(68)^{\star}$ & $\begin{array}{l}\text { Genetic risk score of } 31 \text { SUA } \\
\text { related SNPs }\end{array}$ & 4.2 & $\mathrm{MD} \ddagger$ & $\begin{array}{c}0.000(-0.002 \text { to } \\
0.002)\end{array}$ & NA & NA \\
\hline Triglyceride $(\mathrm{mmol} / \mathrm{L})^{96}$ & Europe & $196621(68)^{\star}$ & $\begin{array}{l}\text { Genetic risk score of } 31 \text { SUA } \\
\text { related SNPs }\end{array}$ & 4.2 & $\mathrm{MD} \ddagger$ & 0.01 (0.01 to 0.02$)$ & NA & NA \\
\hline $\begin{array}{l}\text { Parathyroid hormone } \\
(\mathrm{pg} / \mathrm{mL})^{98}\end{array}$ & China & 1667 & $\begin{array}{l}\text { Genetic risk score of } 5 \text { SUA } \\
\text { related SNPs }\end{array}$ & 1.8 & $\beta$ & $-0.63(-2.12$ to 0.85$)$ & 0.40 & 0.05 \\
\hline Phosphorus (mmol/L) $)^{98}$ & China & 1667 & $\begin{array}{l}\text { Genetic risk score of } 5 \text { SUA } \\
\text { related SNPs }\end{array}$ & 1.8 & $\beta$ & $-0.16(-0.74$ to 0.42$)$ & 0.59 & 0.05 \\
\hline
\end{tabular}


Table 4 (continued)

\begin{tabular}{|c|c|c|c|c|c|c|c|c|}
\hline Outcomes & Population & $\begin{array}{l}\text { No/No of } \\
\text { Events (No of } \\
\text { studies) }{ }^{\star}\end{array}$ & Genetic instruments (GI) & $\begin{array}{c}\text { SUA } \\
\text { variance } \\
\left(R^{2}\right) \\
\text { explained } \\
\text { by GI (\%) }\end{array}$ & $\begin{array}{l}\text { Type of } \\
\text { metric }\end{array}$ & $\begin{array}{l}\text { Estimate of effect } \\
\qquad(95 \% \mathrm{Cl})\end{array}$ & $P$ value & $\begin{array}{c}\text { Statistical } \\
\text { power† }\end{array}$ \\
\hline $\begin{array}{l}\text { C-reactive protein } \\
(\mathrm{mg} / \mathrm{L})^{115}\end{array}$ & Europe & 7158 & $\begin{array}{l}\text { Genetic risk score of } 29 \text { SUA } \\
\text { related SNPs }\end{array}$ & NA & $\beta$ & $-0.05(-0.15$ to 0.05$)$ & 0.37 & NA \\
\hline Calcium (mmol/L) $)^{98}$ & China & 1667 & $\begin{array}{l}\text { Genetic risk score of } 5 \text { SUA } \\
\text { related SNPs }\end{array}$ & 1.8 & $\beta$ & $0.06(-0.10$ to 0.21$)$ & 0.48 & 0.20 \\
\hline $\begin{array}{l}\text { Tropocollagen type } 1 \\
\text { N-terminal propeptide } \\
\text { (ng/L) }\end{array}$ & China & 1667 & $\begin{array}{l}\text { Genetic risk score of } 5 \text { SUA } \\
\text { related SNPs }\end{array}$ & 1.8 & $\beta$ & $0.11(-1.53$ to 1.75$)$ & 0.90 & 0.05 \\
\hline $\begin{array}{l}\beta \text {-crosslaps of type I } \\
\text { collagen containing } \\
\text { cross-linked C } \\
\text { telopeptide }(\mathrm{ng} / \mathrm{L})^{98}\end{array}$ & China & 1667 & $\begin{array}{l}\text { Genetic risk score of } 5 \text { SUA } \\
\text { related SNPS }\end{array}$ & 1.8 & $\beta$ & $-1.45(-3.17$ to 0.27$)$ & 0.10 & 0.05 \\
\hline Calcifediol $(\mathrm{ng} / \mathrm{mL})^{98}$ & China & 1667 & $\begin{array}{l}\text { Genetic risk score of } 5 \text { SUA } \\
\text { related SNPs }\end{array}$ & 1.8 & $\beta$ & $0.76(-0.63$ to 2.15$)$ & 0.28 & 0.05 \\
\hline \multicolumn{9}{|c|}{ All cause and cause specific mortality } \\
\hline $\begin{array}{l}\text { Cardiovascular } \\
\text { mortality }^{99}\end{array}$ & Germany & $3060 / \mathrm{NA}$ & $\begin{array}{l}\text { Genetic risk score of } 8 \text { SUA } \\
\text { related SNPs }\end{array}$ & NA & aHR & $1.11(1.02$ to 1.21$)$ & 0.02 & NA \\
\hline All cause mortality ${ }^{99}$ & Germany & $3060 / \mathrm{NA}$ & $\begin{array}{l}\text { Genetic risk score of } 8 \text { SUA } \\
\text { related SNPs }\end{array}$ & NA & aHR & $1.02(0.95$ to 1.09$)$ & 0.59 & NA \\
\hline Sudden cardiac death 99 & Germany & $3060 / \mathrm{NA}$ & $\begin{array}{l}\text { Genetic risk score of } 8 \text { SUA } \\
\text { related SNPs }\end{array}$ & NA & aHR & $1.18(1.03$ to 1.35$)$ & 0.02 & NA \\
\hline \multicolumn{9}{|l|}{ Other outcomes } \\
\hline Cancer $^{99}$ & Germany & $3060 / 226$ & $\begin{array}{l}\text { Genetic risk score of } 8 \text { SUA } \\
\text { related SNPs }\end{array}$ & NA & OR & 0.95 (0.83 to 1.08$)$ & 0.41 & $0.05 \S$ \\
\hline Gout $^{100}$ & Pakistan & $\begin{array}{c}71501 / 3151 \\
(2)^{*}\end{array}$ & $\begin{array}{l}\text { Genetic risk score of } 14 \text { SUA } \\
\text { related SNPs }\end{array}$ & 3.1 & OR & 5.84 (4.56 to 7.49$)$ & $3.55 \mathrm{E}-40$ & 1.00 \\
\hline
\end{tabular}

SUA=serum uric acid; $N A=$ not available; $\beta=$ regression coefficient; $S N P s=$ single-nucleotide polymorphisms; $M D=$ mean difference; $B M D=b o n e$ mineral density; OR=odds ratio; HR=hazard ratio; T2DM=type 2 diabetes; cIMT=carotid intima-media thickness; eGFR=estimated glomerular filtration rate; aHR=adjusted hazard ratio. *If the outcomes were reported from Mendelian randomisation analysis with pooling multiple studies, the number of studies included in pooled analysis was displayed in brackets. WWhen Mendelian randomisation studies did not provide other necessary information for calculation (eg, standard deviation of serum uric acid levels, standard deviation of outcomes, or the number of cases), the statistical power was not calculated (reported as NA). $¥ M D$ (mean difference) represented the difference in mean caused by per inverse variance weighted allele estimated from pooled analysis. §The statistical power was a crude estimation, as the Mendelian randomisation studies failed to report $R^{2}$; we used the extrapolated $R^{2}$ from other Mendelian randomisation studies that used the same genetic variants as instruments for calculation. "Because of the lack of a standard to covert insulin in different studies to the same scale, sample size-weighted pooled analysis were performed and $Z$ statistics were reported instead of the $\beta$ coefficient. ${ }^{* *}$ Residual variance represented the proportion of residual variance explained by the SUA related SNPs. 


\begin{tabular}{|c|c|c|c|}
\hline Outcomes & $\begin{array}{l}\text { Meta-analysis of } \\
\text { observational studies }\end{array}$ & $\begin{array}{l}\text { Meta-analysis of randomised controlled } \\
\text { trials }^{*}\end{array}$ & Mendelian randomisation studies \\
\hline Heart failure & Class II & NA & Heart failure: $\mathrm{n}=22$ 926, $\mathrm{P}=0.51$, power $=0.11$ ), \\
\hline Hypertension† & Class II & $\begin{array}{l}\text { Systolic blood pressure: } \mathrm{P}=0.001,95 \% \mathrm{PI} \\
\text { included null; diastolic blood pressure: } \mathrm{P}=0.03 \text {, } \\
95 \% \mathrm{PI} \text { included null }\end{array}$ & Hypertension: $\mathrm{n}=3060, \mathrm{P}=0.56$, power $=0.05$ \\
\hline $\begin{array}{l}\text { Impaired fasting glucose or } \\
\text { diabetes }\end{array}$ & Class II & NA & $\begin{array}{l}\text { Diabetes: } n=165482, P=0.79 \text {, power }=0.06 \text { ); } \\
\text { fasting glucose: } n=57397, P>0.05 \text {; fasting insulin: } \\
n=19899, P=0.99\end{array}$ \\
\hline Chronic kidney disease $†$ & Class II & $\begin{array}{l}\text { Serum creatinine: } \mathrm{P}<0.001,95 \% \mathrm{PI} \text { included } \\
\text { null; estimated glomerular filtration rate: } \\
\mathrm{P}=0.010,95 \% \mathrm{PI} \text { included null; end stage renal } \\
\text { disease: } \mathrm{P}<0.001,95 \% \mathrm{PI} \text { excluded null }\end{array}$ & $\begin{array}{l}\text { Chronic kidney disease: } n=23387 ; P=0.12 \text {, } \\
\text { power=0.70; adverse renal events: } n=755, P=0.01 \text {; } \\
\text { serum creatinine: } n=7979, P=0.07 ; \text { estimated } \\
\text { glomerular filtration rate: } n=23844, P=0.91 \text {, } \\
\text { power }=0.05\end{array}$ \\
\hline $\begin{array}{l}\text { Coronary heart disease } \\
\text { mortality† }\end{array}$ & Class II (general population) & NA & $\begin{array}{l}\text { Coronary heart disease incidence: } n=206822 \text {, } \\
P=0.49 \text {, power }=0.57\end{array}$ \\
\hline Recurrence of nephrolithiasis & NA & $\begin{array}{l}\text { Citrates treatment: } \mathrm{P}<0.001,95 \% \mathrm{PI} \text { excluded } \\
\text { null; thiazides treatment: } \mathrm{P}<0.001,95 \% \mathrm{PI} \\
\text { excluded null }\end{array}$ & NA \\
\hline
\end{tabular}

$\mathrm{NA}=$ not applicable; $\mathrm{Pl}=$ prediction interval. *Data presented on largest meta-analysis of randomised controlled trials for each outcome. $\dagger$ lf there were no identical outcomes investigated in meta-analyses of randomised controlled trials and/or Mendelian randomisation studies to match with class I or II observational associations, the corresponding intermediate traits were juxtaposed as surrogates for comparison. 


\section{Figure}

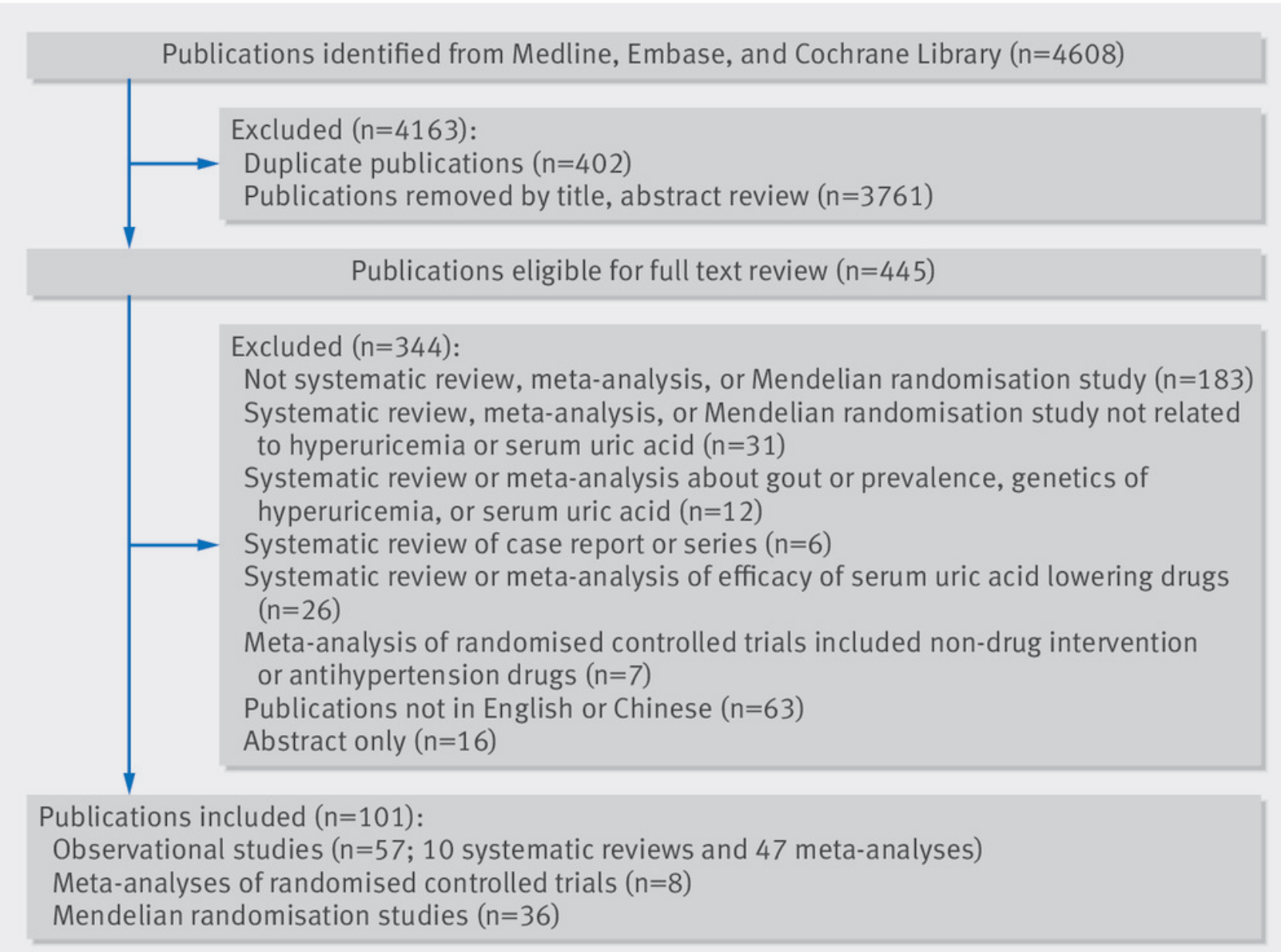

Fig 1 Study flowchart 